Abteilung Dermatologie, Venerologie und Allergologie

(Prof. Dr. med. M. Schön)

im Zentrum Arbeits-, Sozial-, Umweltmedizin und Dermatologie der

Medizinischen Fakultät der Universität Göttingen

\title{
Etablierung eines Plasmid-basierten \\ Testsystems zur funktionellen Messung der zellulären Doppelstrangbruch- Reparaturfähigkeit in hämatopoetischen Zellen
}

\author{
INAUGURAL-DISSERTATION \\ zur Erlangung des Doktorgrades \\ der Medizinischen Fakultät \\ der Georg-August-Universität zu Göttingen \\ vorgelegt von \\ Julia Hermann \\ aus Bremen
}

Göttingen 2010 
Dekan: Prof. Dr. med C. Frömmel

I. Berichterstatter: Prof. Dr. med. S. Emmert

II. Berichterstatter/in:

III. Berichterstatter/in:

Tag der mündlichen Prüfung: 


\section{Inhaltsverzeichnis}

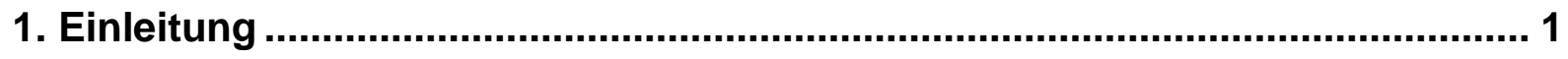

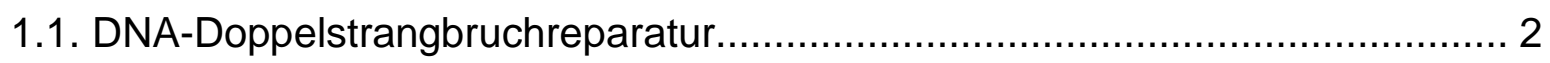

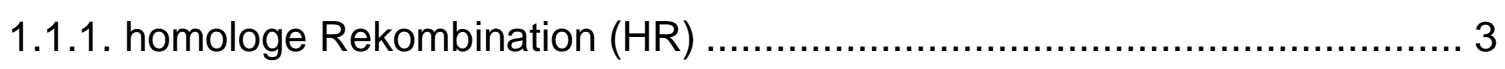

1.1.2. „Non-homologous end-joining (NHEJ)" ............................................... 4

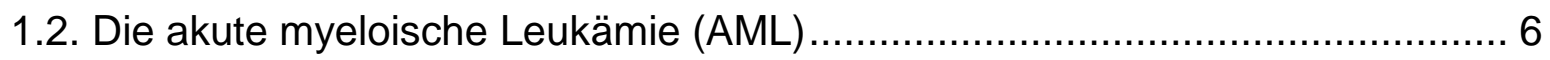

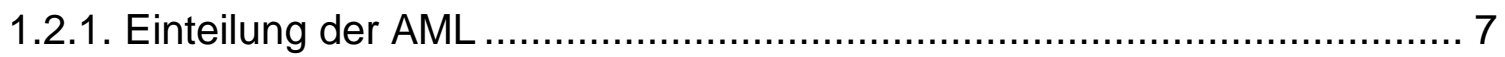

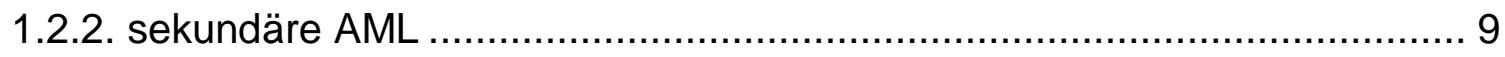

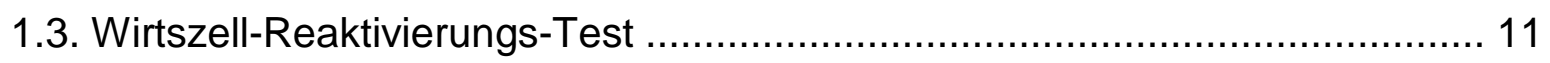

1.3.1. Nachweis der Firefly-Luciferase-Reportergen-Aktivität.......................... 13

1.3.2. Nachweis der Renilla- Luciferase-Reportergen-Aktivität ........................ 14

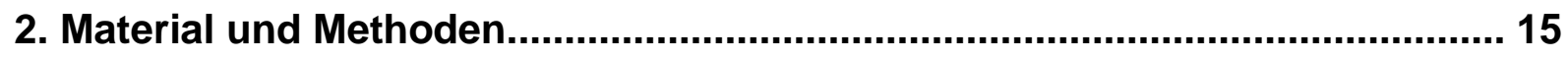

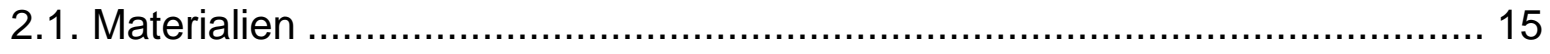

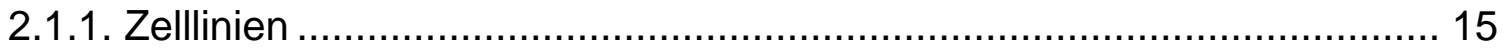

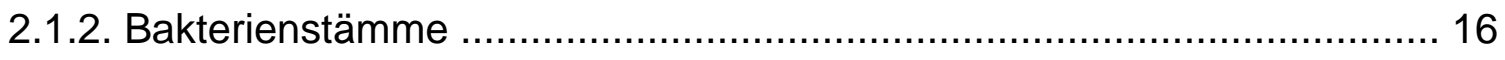

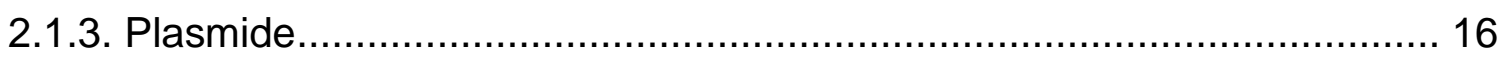

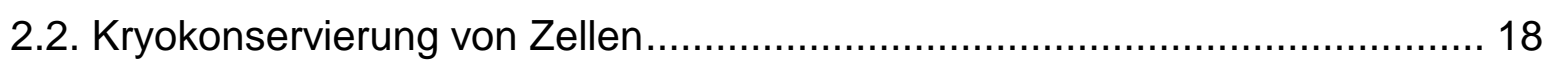

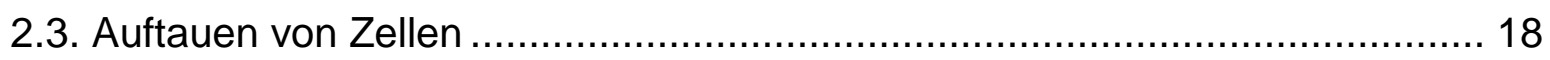

2.4. Bestimmung der Zellzahl.................................................................. 19

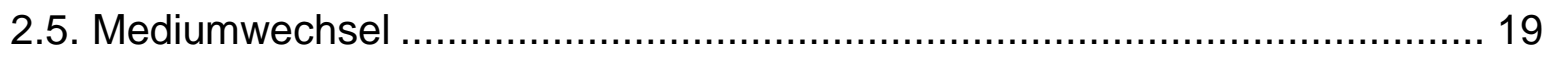

2.6. Ficoll-Gradient zum Waschen der Zellen ............................................... 19

2.7. Isolierung der mononukleären Zellen aus Patientenblut mittels Ficoll-

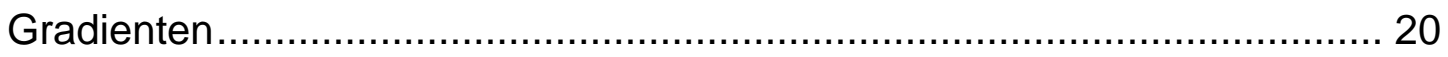

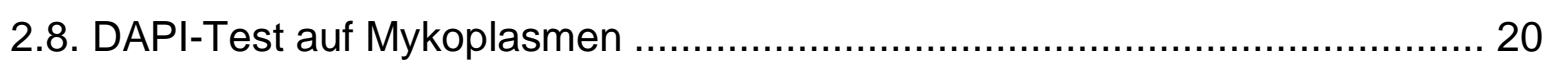

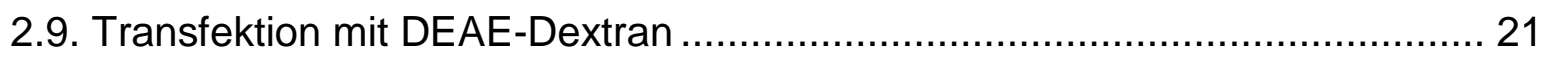

2.10. Herstellung kompetenter Bakterienstämme …....................................... 23

2.10.1. Herstellung kompetenter Bakterienstämme für die Hitzeschocktransformation............................................................ 23

2.10.2. Herstellung kompetenter Bakterienstämme für die Elektroporation....... 24

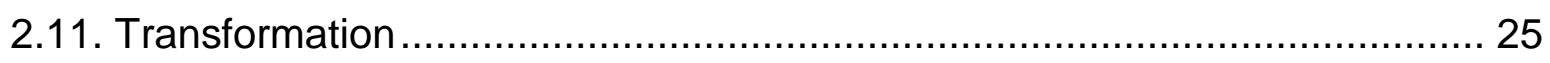

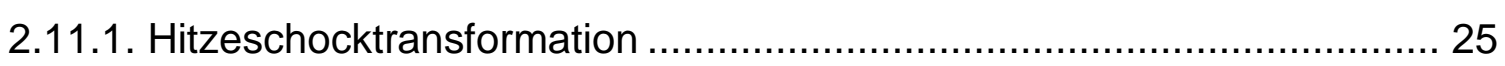

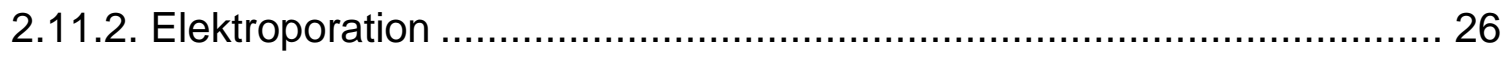




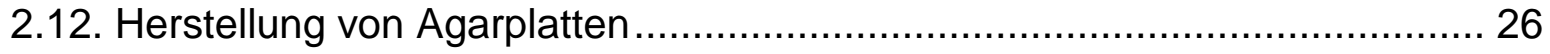

2.13. Aufreinigung von Plasmid-DNA (Midi Prep) …......................................... 26

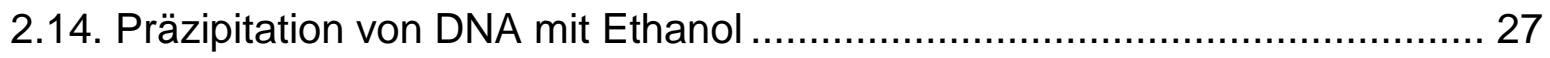

2.15. Konzentrationsbestimmung von Nukleinsäuren ..................................... 27

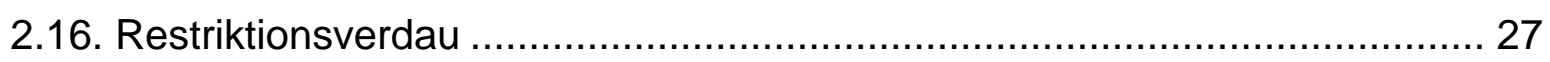

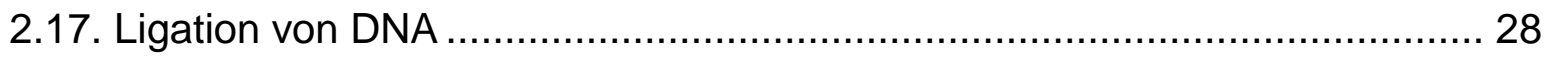

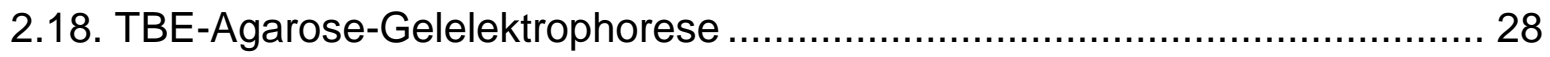

2.19. Gewinnung von DNA-Fragmenten aus Agarosegelen .............................. 29

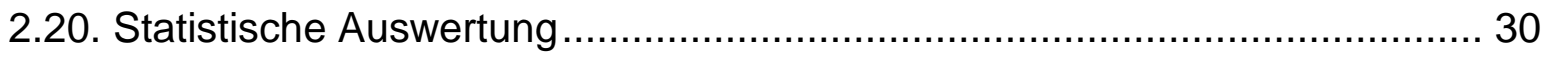

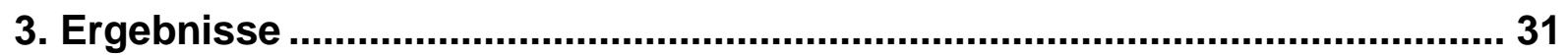

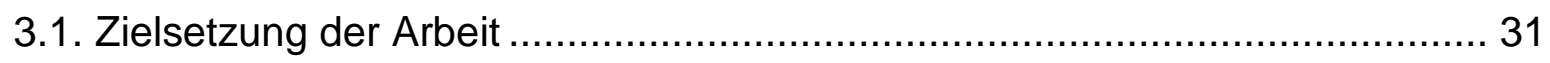

3.2. Etablierung des Testsystems in primären Blutlymphozyten (PBL) und

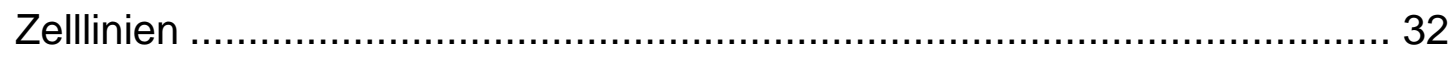

3.3. Optimierung der Transfektionsbedingungen für Leukämiezelllinien.............. 34

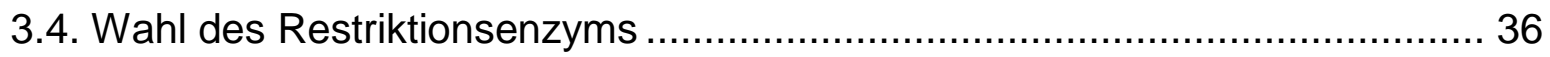

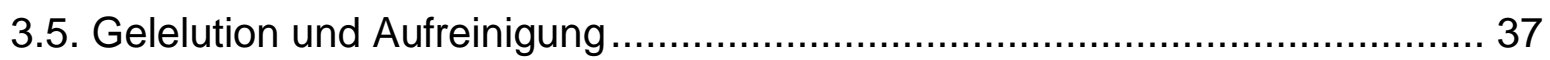

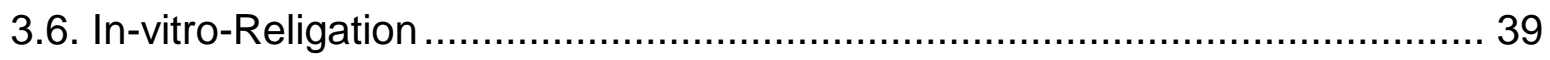

3.7. DSB-Reparatur in menschlichen primären Tumorzellen ............................... 41

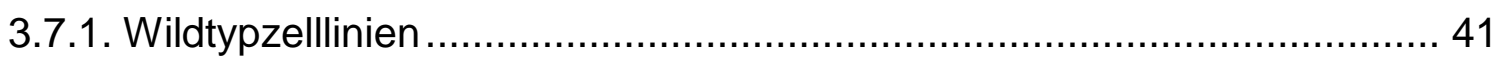

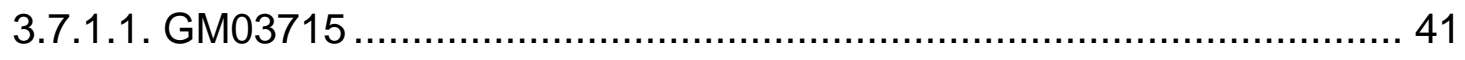

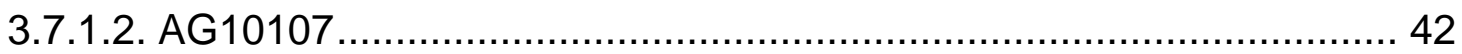

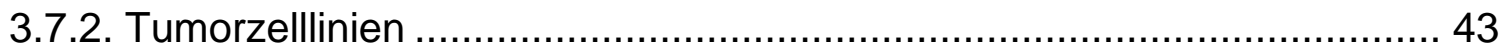

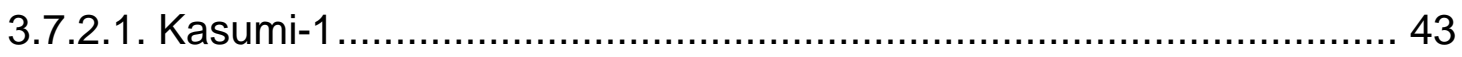

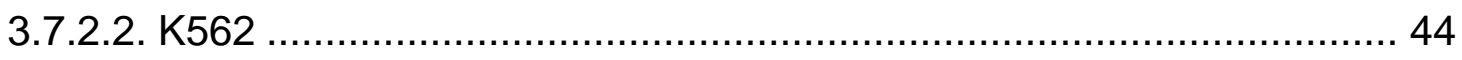

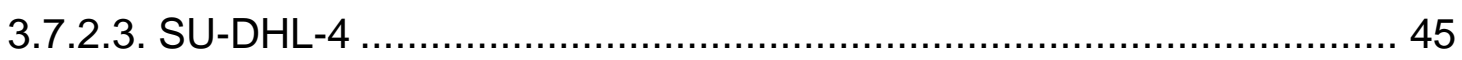

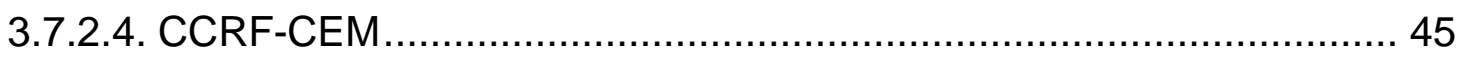

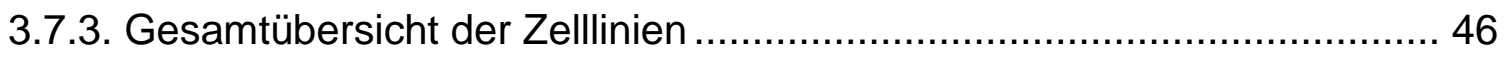

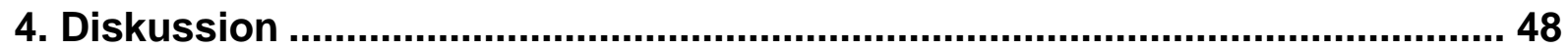

4.1. Doppelstrangbruchreparatur und Leukämien............................................ 48

4.2. Wirtszell-Reaktivierungs-Test als geeignete Funktionsuntersuchung für

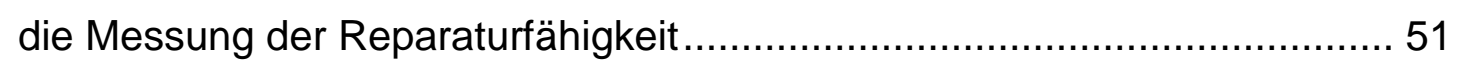

4.3. Etablierung des Testsystems in primären Blutlymphozyten ......................... 52

4.4. Etablierung des Testsystems in Tumorzellen von Patienten ......................... 52 
4.4.1. Die AML-Zelllinie Kasumi-1 zeigt eine signifikant erniedrigte Reparaturkapazität. 53

4.4.2. Die CML-Zelllinie K562 zeigt keine verminderte DSB-Reparaturkapazität.

4.4.3. In der B-Zell-Lymphom-Zelllinie SU-DHL-4 ist die DSB-Reparaturkapazität signifikant erniedrigt...

4.4.4. Die Reparaturkapazität der T-Zell-Leukämie-Zelle CCRF-CEM ist nicht erniedrigt 60

5. Zusammenfassung. 62

6. Literaturverzeichnis 64 


\section{Abkürzungsverzeichnis}

AML

t-AML

AMP

AT

ATM

ATP

ATR

bp

BRCA

${ }^{\circ} \mathrm{C}$

CD

CML

DAPI

DEAE

DNA

DNA-PK

DNA-PKcs

DSB

FA

FEN1

g

G (in G1, G2)

Gy

$\mathrm{h}$

HCR

HR

$\operatorname{inv}(\ldots)$

$k B$

$\mathrm{kDa}$

I

LB

M akute myeloische Leukämie

therapieassoziierte akute myeloische Leukämie

Adenosinmonophosphat

Ataxia telangiectasia

„ataxia telangiectasia mutated“

Adenosintriphosphat

„ataxia telangiectasia related“

„base pair(s)“ (Basenpaare)

„breast cancer susceptibility gene“

Grad Celsius

"cluster of differentiation"

chronisch myeloische Leukämie

4,6-Diamidinophenylindol

Diethylaminoethyl

„deoxyribonucleic acid“ (Desoxyribonukleinsäure)

DNA-abhängige Proteinkinase

DNA-PK „catalytic subunit" (katalytische Untereinheit)

Doppelstrangbruch

Fanconi-Anämie

„flap structure-specific endonuclease 1"

Gramm

"gap“ (Lücke)

Gray

"hour" (Stunde)

„host cell reactivation“ (Wirtszell-Reaktivierung)

homologe Rekombination

Inversion

Kilobasen

Kilodalton

Liter

"lysogeny broth"

molare Masse 
m

$\min$

mRNA

NBS

NHEJ

B-NHEJ

D-NHEJ

$\Omega$

OD

$\mathrm{p}$

PBL

PBS

$\mathrm{pH}$

RLU

RNA

rpm

sek

S-Phase

STBS

Sv

$\mathrm{t}(\ldots)$

TBE

Tris

UV

$\mathrm{V}$

$\mathrm{V}(\mathrm{D}) \mathrm{J}$

$\mathrm{v} / \mathrm{v}$

$\mathrm{w} / \mathrm{v}$

XRCC

Präfixe:
Meter

Minute

„messenger ribonucleic acid“ (Boten-Ribonukleinsäure)

„Nijmegen-Breakage-Syndrom“

„Non-homologous end-joining“

$$
\text { „backup“ (Reserve) }
$$

$$
\text { „dependent“" (abhängig von DNA-PK) }
$$

Ohm

Optische Dichte

Irrtumswahrscheinlichkeit

primäre Blutlymphozyten

„phosphate buffered saline“ (Phosphatgepufferte Salzlösung)

$-\log [\mathrm{H}+]$

„relative light units“ (relative Lichteinheiten)

„ribonucleic acid“ (Ribonukleinsäure)

„revolutions per minute“ (Umdrehungen pro Minute)

Sekunde

Synthesephase

„suspension tris buffered saline” (suspendierte trisgepufferte

Salzlösung)

Sievert

Translokation

„TRIS-Borat-EDTA“

„Tris-(hydroxymethyl-)aminomethan“

Ultraviolett

Volt

„Variable (division) joining”

„Volume per volume” (Volumen pro Volumen)

„weight per volume” (Masse pro Volumen)

„X-ray-cross-complementing”

m Milli $\left(10^{-3}\right)$

$\mu \quad \operatorname{Mikro}\left(10^{-6}\right)$

n Nano $\left(10^{-9}\right)$ 


\section{Einleitung}

Um eine möglichst exakte Weitergabe von genetischen Informationen einer Zelle an die Tochterzellen zu garantieren, haben Zellen im Laufe der Evolution hochspezifische Methoden entwickelt, die es innen ermöglichen, ihre genetische Integrität zu überwachen und zu bewahren. Mögliche Reaktionen einer Zelle auf einen DNA-Schaden beinhalten Zell-Zyklus-Arrest, Transkription und Aktivierung von DNA-Reparatur-Proteinen sowie die Triggerung von Apoptose. Die Unfähigkeit, DNA-Veränderungen zu erkennen bzw. diese zu reparieren, geht mit einem erhöhten Risiko der Krebsentstehung einher (Khanna und Jackson 2001). Da die Tumorgenese allerdings ein mehrschrittiger Prozess ist, müssen für eine maligne Entartung in der Regel mehrere Mutationsereignisse in einer Zelle zusammenkommen.

Insbesondere Doppelstrangbrüche beinhalten ein hohes Potenzial für Chromosomenaberrationen. Fehlerhafte Verknüpfung der Doppelstrangbruch-Enden kann unter ungünstigen Umständen zu Translokationen führen, bei denen ein Bruchstück auf ein anderes Chromosom übertragen wird. Ein solches chromosomales Rearrangement kann zur Aktivierung von Proto-Onkogenen oder zum Funktionsverlust von Tumor-Suppressor-Genen führen. Proto-Onkogene sind typischerweise in die Regulation von Wachstum und Differenzierung involviert, während Tumor-Suppressor-Gene, wie zum Beispiel p53, häufig eine wichtige Aufgabe in der Zellzykluskontrolle haben und Apoptose auslösen können.

Durch die Fehlfunktion kommt es zu unkoordiniertem, räumlich und zeitlich unbegrenztem Wachstum aufgrund einer unkontrollierten Zellteilung. Typischerweise folgt im Verlauf eine zunehmende Autonomie mit Unabhängigkeit von extrazellulären Wachstumsfaktoren, Verlust der Kontakthemmung und verringerter Anheftungsabhängigkeit. Dies führt in der Folge zu organüberschreitendem Wachstum und Metastasierung (Kinzler und Vogelstein 1997; Lengauer et al. 1998; Lodish et al. 2001) bzw. zur Hemmung der physiologischen Differenzierung bei gleichzeitig unkontrolliertem Wachstum und einer leukämischen Ausschwemmung. 


\subsection{DNA-Doppelstrangbruchreparatur}

Doppelstrangbrüche werden als die kritische Primärläsion für die Entstehung von Chromosomenaberrationen angesehen, welche die Grundlage für eine maligne Entartung bilden. Anders als bei Läsionen, die nur einen Strang der Doppelhelix betreffen (zum Beispiel Einzelstrangbrüche), fehlt bei der DSB-Reparatur die komplementäre Helix als vollständige Reparaturvorlage.

DSB entstehen durch verschiedene exogene DNA-schädigende Einflüsse oder durch endogene Zellprozesse. Beispiele für exogene Einflüsse sind ionisierende Strahlen und Chemotherapeutika wie Topoisomerase-II-Inhibitoren oder Bleomycin. Endogene Prozesse beinhalten Doppelstrangbrüche durch freie Radikale oder Einzelstrangbrüche des parenteralen Strangs in der S-Phase der Mitose. Burma et al. schätzen die tägliche Zahl der endogen entstehenden DSB auf 10 bis 100 Ereignisse pro Zelle (Burma et al. 2006).

Besondere Fälle endogener Strangbrüche, weil erwünscht und kontrolliert von der Zelle herbeigeführt, sind DSB während der V(D)J-Rekombination, beim Immunglobulin-Klassenwechsel und in der Meiose (Khanna und Jackson 2001; Elliott und Jasin 2002; Pfeiffer et al. 2004).

Für die Reparatur dieser DNA-Schäden hat die Zelle außer dem Weg in die Apoptose zwei verschiedene Reparaturwege zur Auswahl: homologe Rekombination (HR) und "Non-homologous end-joining (NHEJ)“. Beide Wege sind hochkomplex und evolutionär gut erhalten (Jackson 2002). 
exogene und endogene DNA-

schädigende Einflüsse

Replikationsstress

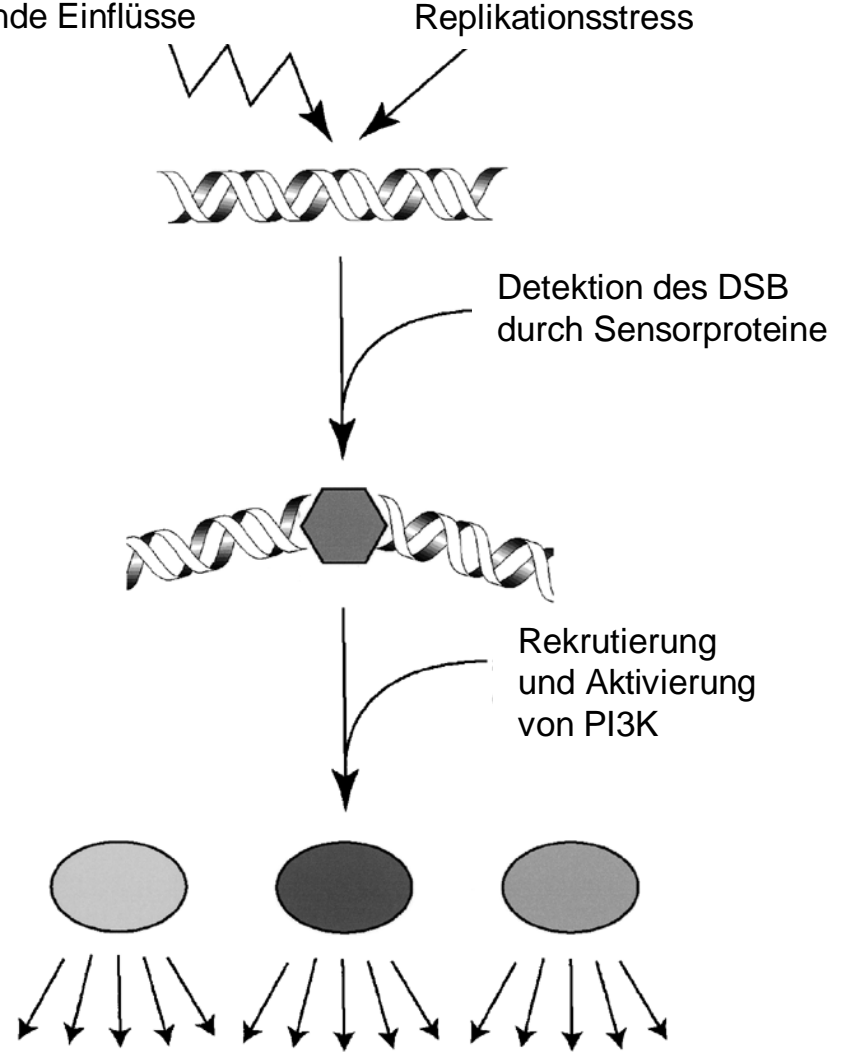

Rekrutierung und Aktivierung weiterer

Signaltransduktionskaskaden

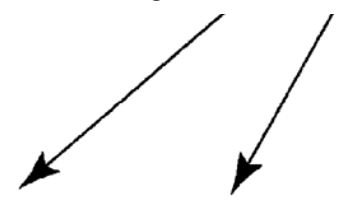

Apoptose Transkriptionsregulation

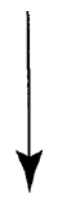

Zellzykluskontrolle

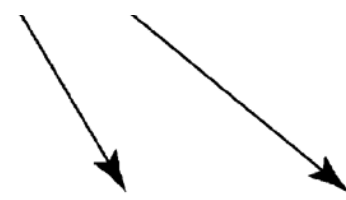

HR

NHEJ

Abbildung 1: Detektion und Signalkaskade von DNA-Doppelstrangbrüchen (nach Bradbury und Jackson 2003 S.41): Initial wird der DNA-Schaden durch Sensorproteine erkannt und durch eine Reihe von Proteinkinasen verstärkt und weitergeleitet. In menschlichen Zellen sind dafür insbesondere 3 verschiedene Phosphatidylinositol-3-Kinase-verwandte Kinasen (PI3K) verantwortlich: ATM, ATR und DNA-PK $K_{c s}$. Diese rekrutieren und aktivieren verschiedene Signaltransduktionskaskaden für allgemeine Zellantworten (Apoptose, Transkriptionsregulation und Zellzyklusarrest) und spezielle Reparaturmechanismen (HR oder NHEJ).

\subsection{1. homologe Rekombination (HR)}

Die homologe Rekombination dominiert vor allem in der S- bzw. G2-Phase des Zellzyklus und benötigt eine homologe Sequenz von üblicherweise $\geq 200$ bp (Hoeijmakers 2001; Elliott und Jasin 2002). Bei diesem Reparaturweg wird noch 
einmal zwischen Genkonversion und „single-strand-annealing (SSA)“ unterschieden (Karran 2000).

Die Genkonversion ist ein konservativer homologer Rekombinationsprozess, bei dem die geschädigte Sequenz vollständig rekonstruiert wird. Notwendig ist das Vorhandensein einer entsprechenden Matrize auf dem Schwesterchromatid oder dem homologen Chromosom. Dieses dient als Vorlage, um die beiden Strangenden wieder exakt zu verbinden. Nach Erkennung des Doppelstrangbruchs durch RAD52 und der nukleolytischen Prozessierung, bei der der RAD50-MRE11-NBS1-Komplex und ATM eine wesentliche Rolle spielen, interagieren das RAD51-NukleoproteinFilament mit dem homologen, unversehrten DNA-Strang des Schwesterchromosoms. Dazu gehört auch die Interaktion mit XRCC-3, einem RAD51-ähnlichem Protein. Die prozessierten 3'Enden des defekten Stranges dringen in den parallelen Strang ein und es erfolgt die DNA-Synthese. Die entstandenen „Holiday-junctions“ werden nun vor allem ohne „cross over" aufgelöst (Dronkert et al. 2000; Johnson und Jasin 2000).

Ein Zusammenhang zwischen Tumorrisiko und HR scheint durch die Interaktion von BRCA1 und BRCA2 mit RAD51 bei der HR bewiesen zu sein. BRCA1 und BRCA2 gehören zu der Gruppe der Tumor-Suppressor-Gene und viele Patienten mit familiärem Brust- bzw. Eierstockkrebs weisen Mutationen in diesen Genen auf, wobei auch die HR deutlich erniedrigt ist (Johnson und Jasin 2000). Die beiden Proteine interagieren neben vielen weiteren Partnern der Reparatur- und KontrollpunktKaskaden auch mit Rad51 und beeinflussen so dessen Aktivität (Thompson und Schild 2002).

Die zweite Unterform der HR, das nicht-konservative „single-strand-annealing“, wird häufig bei zwei oder mehr aufeinanderfolgenden Wiederholungssequenzen eingesetzt. Dabei gehen allerdings DNA-Abschnitte (ein bzw. mehrere solcher „repeats“) verloren.

\subsection{2. „Non-homologous end-joining (NHEJ)”}

Die Reparatur durch NHEJ ist der vorherrschende Doppelstrangbruchreparaturmechanismus beim Menschen (Karran 2000). Dieser weniger akkurate, aber sehr zügige Mechanismus ist vor allem in der G1-Phase des Zellzyklus relevant, wenn keine zweite Genom-Kopie als Vorlage dienen kann (Hoeijmakers 2001). Des 
Weiteren scheint das menschliche Genom aufgrund seiner Größe und Komplexität für die Suche nach homologen Sequenzen (notwendig für eine präzise DSBReparatur durch HR) nicht so geeignet zu sein (Wang HC et al. 2006).

Das NHEJ verbindet die Bruchenden direkt ohne homologe Sequenz. Gelegentlich beinhaltet das NHEJ Sequenzveränderungen durch kurze Deletionen von weniger als 20 bp zurück zu Regionen mit Mikrohomologien von ein bis sechs Basenpaaren, das heißt der Reparaturprozess selbst ist fehlerhaft (Gaymes et al. 2002a).

Dabei ist die Gefahr, dass geringe Sequenzveränderungen (vor allem Deletionen) an den Bruchpunkten eine kritische Region eines wichtigen Gens betreffen, relativ gering, da:

1. mit etwa $1 \%$ nur ein kleiner Teil des menschlichen Genoms codierende Regionen trägt,

2. das zweite, intakte Allel das defekte Allel kompensiert und

3. irreversibel genetisch geschädigte Zellen in der Regel in die Apoptose gehen (Pfeiffer et al. 2004).

Da im Moment der Schädigung schon Nukleotide verloren sind, ist der zusätzliche Verlust von wenigen weiteren Nukleotiden von geringer zusätzlicher Konsequenz, insbesondere unter Berücksichtigung der möglichen Folgen fehlender chromosomaler Integrität. Dies hat unter evolutionären Aspekten vermutlich zu der im Folgenden dargestellten Flexibilität und Komplexität dieses Systems geführt (Lieber 2008).

Verschiedene Proteine konnten in den letzten Jahren für das NHEJ herausgestellt werden. Die DNA-abhängige Proteinkinase DNA-PK, welche aus dem Ku70/80Heterodimer und der katalytischen Untereinheit der DNA-PKCS („catalytic subunit“) besteht, ist vermutlich in der frühen Phase der DSB-Reparatur beteiligt (Smith GC und Jackson 1999). Dabei deutet die hohe Affinität des $K u$-Heterodimers zu den Bruchenden auf seine Beteiligung in der DSB-Erkennung sowie dem Schutz der Enden vor unkontrolliertem Abbau hin. Anschließend rekrutiert das DNA-gebundene Heterodimer die DNA-PKcs, welche wahrscheinlich die Läsion überbrückt und die folgenden Reparaturproteine aktiviert (Cary et al. 1997; Walker et al. 2001). Dazu gehören unter anderem der MRE11-RAD50-NBS1-Komplex sowie ATM, BRCA1, Artemis- und das FEN1-Protein, welche für Zellzyklusarrest und die Prozessierung zuständig sind. Letzteres wird für die Religation ungleicher Enden benötigt. Der 
abschließende Ligationsschritt wird durch den XRCC4/Ligase-IV-Komplex im Zusammenspiel mit dem Faktor Cernunnos-XLF durchgeführt (van Heemst et al. 2004; Wu et al. 2007). Interessanterweise kann der Ligasekomplex eine Stranghälfte auch dann ligieren, wenn die gegenseitige Stranghälfte aufgrund einer Hydroxygruppe am 5'Ende der DNA nicht ligierbar ist oder eine Lücke von einigen Nukleotiden überbrückt werden muss (Gu et al. 2007).

Offensichtlich gibt es neben dem beschriebenen Mechanismus des NHEJ noch mindestens eine weitere Variante. Diese arbeitet deutlich langsamer, ist dafür von der Ligase-IV, Ku80 und der DNA-PKCs unabhängig. Zur Unterscheidung wird dieser Weg als B-NHEJ („backup“) bezeichnet, die schnellere Variante dagegen als DNHEJ („dependent“ bezüglich der DNA-PK) oder auch C-NHEJ („core“-NHEJ mit den Kernelementen Ligase-IV und $K u$ ) (Wang $\mathrm{H}$ et al. 2003; Nussenzweig und Nussenzweig 2007). Die beiden Wege sind komplementär zueinander, wobei DNHEJ dominiert. Erst bei Beeinträchtigung des D-NHEJ (durch Mutationen bzw. Abwesenheit von Elementen wie Ligase-IV, $K u$ oder $\left.D N A-P K_{c s}\right)$ übernimmt der BNHEJ vollständig. Durch die langsamere Kinetik liegen jedoch zeitgleich mehrere freie DNA-Enden vor, was die Gefahr einer fehlerhaften Verbindung erhöht (DiBiase et al. 2000; lliakis et al. 2004).

Für die Aktivierung der HR respektive des NHEJ spielen vor allem Rad52 und das $\mathrm{Ku}$-Heterodimer eine entscheidende Rolle. Rad52 und das $\mathrm{Ku}$-Heterodimer konkurrieren um die Bindungsstelle der freien DNA-Enden. Dabei leitet die Bindung des jeweiligen Proteins den entsprechenden Reparaturweg ein (Emmert et al. 2006).

\subsection{Die akute myeloische Leukämie (AML)}

Der Ausdruck "Leukämie“ (= weißes Blut) wurde erstmals 1845 von Rudolf Virchow eingeführt, der im Blut einer Patientin eine erhebliche Vermehrung weißer Zellen fand. Heute fasst man unter diesem Begriff die bösartigen Erkrankungen der weißen Blutkörperchen (Leukozyten) zusammen (Virchow 1845).

Ein auffälliges Merkmal der meisten Leukämien ist die deutlich erhöhte Zahl von Translokationen, Deletionen und Allelverlusten (Rassool 2003). Dies führt zur 
„Akkumulation teilungsfähiger, aber abnormer, funktionell unreifer myeloischer Zellen in Blut und Knochenmark" (Christ et al. 2007 S.290). In der Folge kommt es zur Verdrängung der normalen Hämatopoese.

Bei der AML beträgt die Zeitspanne zwischen ersten Krankheitszeichen und Diagnosestellung aufgrund des raschen Verlaufs der Erkrankung meist nur einige Wochen. Die unterschiedlichen und unspezifischen Symptome sind vor allem Ausdruck der Zytopenie. Dazu gehören bei vielen Patienten eine verstärkte Blutungsneigung, Abgeschlagenheit, Belastungsdyspnoe, Infektneigung, Fieber, Nachtschweiß und seltener Knochenschmerzen. Gelegentlich kommt es auch zur leukämischen Infiltration anderer Gewebe, zum Beispiel Leber (Hepatomegalie), Milz (Splenomegalie), Haut („leukemia cutis“), Lymphknoten (Lymphadenopathie) und Knochen. Selten kommt es zu einer Leukozytose von über 100000/ $\mu$ mit der Folge (cerebro-) vaskulärer Komplikationen (Löwenberg et al. 1999; Kern et al. 2003).

Die AML weist ein medianes Erkrankungsalter zwischen 65 und 70 Jahren auf (Estey 2007) und ist mit 3,8 Erkrankungen/100.000 Einwohner/Jahr die häufigste myeloische Leukämie. Da sie eine typische Erkrankung des Seniums ist, steigt die Inzidenz in der Altersgruppe >65 Jahren auf 17,5 Erkrankungen/100.000 Einwohner/Jahr (Estey und Döhner 2006).

\subsubsection{Einteilung der $A M L$}

Bei der AML kommt es je nach Reifungsstopp zu verschiedenen Subtypen der Erkrankung. Die gebräuchlichste Einteilung ist die modifizierte French-AmericanBritish- (FAB-) Klassifikation nach Zelllinie und Differenzierungsgrad, die von Benett et al. 1976 eingeführt wurde (Bennett et al. 1976; Bennett et al. 1985). Diese Einteilung basiert auf zytomorphologischen Kriterien und fordert einen Blastenanteil von $>30 \%$ im Knochenmark. Daneben gibt es seit 1999 eine zweite Klassifikation durch die World Health Organisation (WHO). Diese beinhaltet neben morphologischen Kriterien auch spezifische genetisch differenzierbare Subgruppen (Harris et al. 1999). 
Tabelle 1: French-American-British- (FAB-) Klassifikation der AML und assoziierte genetische Veränderungen (nach Löwenberg et al. 1999 S.1052 und Kern et al. 2003 S.20)

\begin{tabular}{|c|c|c|c|c|}
\hline \multirow[t]{2}{*}{$\begin{array}{l}\text { FAB- } \\
\text { Subgruppe }\end{array}$} & \multirow[t]{2}{*}{ Name } & \multirow[t]{2}{*}{ Häufigkeit } & \multicolumn{2}{|c|}{$\begin{array}{l}\text { Typische assoziierte } \\
\text { Veränderungen }\end{array}$} \\
\hline & & & $\begin{array}{l}\text { a) zyto- } \\
\text { genetisch }\end{array}$ & $\begin{array}{l}\text { b) molekular- } \\
\text { genetisch }\end{array}$ \\
\hline MO & $\begin{array}{l}\text { akute unreife } \\
\text { Myeloblastenleukämie } \\
\text { mit minimaler } \\
\text { Differenzierung }\end{array}$ & $3 \%$ & & \\
\hline M1 & $\begin{array}{l}\text { akute unreife } \\
\text { Myeloblastenleukämie }\end{array}$ & $15-20 \%$ & $\mathrm{t}(8 ; 21)$ & AML1/ETO \\
\hline M2 & $\begin{array}{l}\text { akute } \\
\text { Myeloblastenleukämie } \\
\text { mit Ausreifung } \\
\text { M2Baso mit Basophilie }\end{array}$ & $25-30 \%$ & $\mathrm{t}(8 ; 21)$ & AML1/ETO \\
\hline M3 & $\begin{array}{l}\text { akute } \\
\text { Promyelozytenleukämie }\end{array}$ & $5-10 \%$ & $\mathrm{t}(15 ; 17)$ & PML/RAR a \\
\hline M4 & $\begin{array}{l}\text { akute myelomonozytäre } \\
\text { Leukämie } \\
\text { M4Eo mit >5\% abnormen } \\
\text { Eosinophilen }\end{array}$ & $20 \%$ & $\begin{array}{l}\operatorname{inv}(16) / \\
t(16 ; 16)\end{array}$ & CBFß/MYH11 \\
\hline M5 & $\begin{array}{l}\text { akute } \\
\text { Monoblastenleukämie } \\
\text { M5a ohne Ausreifung } \\
\text { M5b mit Ausreifung }\end{array}$ & $2-9 \%$ & $\begin{array}{l}11 q 23 \\
\text { Aberration }\end{array}$ & MLL-Aberr \\
\hline M6 & akute Erythroleukämie & $3-5 \%$ & & \\
\hline M7 & $\begin{array}{l}\text { akute Megakaryoblasten- } \\
\text { leukämie }\end{array}$ & $3-12 \%$ & & \\
\hline
\end{tabular}


Tabelle 2: World Health Organisation- (WHO-) Definition (nach Harris et. al 1999 S.3836)

\section{AML mit wiederkehrenden genetischen Abnormalitäten}

- $\quad \mathrm{AML}$ mit $\mathrm{t}(8 ; 21)(\mathrm{q} 22 ; \mathrm{q} 22)$ (AML1/ETO Rearrangement)

- akute Promyelozytenleukämie mit t(15;17)(q22;q12) (PML/RARa) und Varianten,

- $\quad$ AML mit abnormen Knochenmark-Eosinophilen inv(16)(p13;q22) oder $\mathrm{t}(16 ; 16)(\mathrm{p} 13 ; \mathrm{q} 22)(\mathrm{CBF} / \mathrm{MYH} 11)$

- AML mit 11q23 Veränderungen (MLL-Gen)

AML mit multilinearer Dysplasie

- mit vorhergegangenem myelodysplastischem Syndrom

- ohne vorhergegangenes myelodysplastisches Syndrom

\section{Therapiebedingte AML}

- nach alkylierenden Substanzen

- nach Epipodophyllotoxinen

- andere

\section{AML nicht näher klassifiziert}

- $\quad$ AML mit minimaler Differenzierung

- AML ohne Ausreifung

- AML mit Ausreifung

- akute myelomonozytäre Leukämie

- akute monozytäre Leukämie

- akute erythroide Leukämie

- akute Basophilenleukämie

- akute Panmyelose mit Myelofibrose

\section{akute biphänotypische Leukämie}

\subsection{2. sekundäre $A M L$}

Die Mehrheit der AML-Erkrankten weist keinerlei Risikofaktoren auf, die die Entwicklung der Krankheit begründen. Diese Form wird daher als primäre (oder denovo-) AML bezeichnet. Demgegenüber entsteht eine sekundäre AML auf dem Boden hämatologischer Funktionsstörungen (zum Beispiel schwerer kongenitaler 
Neutropenie), angeborener Instabilitätssyndrome (beispielsweise Bloom Syndrom oder Fanconi-Anämie) oder nach einem myelodysplastischen Syndrom. Eine besondere Unterform der sekundären Leukämie ist die therapieassoziierte AML (t$\mathrm{AML}$ ), welche nach Therapie mit leukämogenen Substanzen im Rahmen einer Chemotherapie auftritt (Löwenberg et al. 1999). Dies kommt bei etwa 5-15\% der Patienten vor.

Bei der t-AML unterscheidet man zwei Subtypen. Der häufigere tritt 5-10 Jahre nach Therapie mit alkylierenden Agenzien auf und zeigt Monosomien oder Deletionen der langen Arme von Chromosom 5 oder 7. Die zweite Form der t-AML tritt typischerweise 2-5 Jahre nach Chemotherapie mit Topoisomerasehemmern wie beispielsweise Etoposid auf. Diese t-AML ist durch charakteristische balanzierte Translokationen, die mit einer Häufigkeit von 10-40\% auftreten, gekennzeichnet. An diesen Translokationen sind überzufällig häufig bestimmte Gene beteiligt. Es handelt sich hierbei insbesondere um Translokationen des MLL- (11q23) und des AML1 Gens (21q22) (Felix 1998; Seedhouse und Russell 2007).

Obwohl nur wenige Patienten nach Chemotherapie eine t-AML entwickeln, nahm die Zahl der Betroffenen durch die vermehrte Nutzung von Chemotherapeutika in der älter werdenden Gesellschaft und durch verbesserte Überlebensraten in den letzten Jahrzehnten zu (Seedhouse und Russell 2007). Deshalb ist es umso wichtiger jene Risikofaktoren zu identifizieren, welche mit einer Prädisposition für eine t-AML einhergehen.

Ergebnisse verschiedener genetischer Polymorphismenstudien deuten an, dass zwischen therapieassoziierter und de-novo-AML ein Unterschied der Reparaturaktivität bestehen könnte. Als Erste konnten Seedhouse et al. zeigen, dass Polymorphismen in Genen von RAD51 und XRCC3 als Komponenten der HR mit einem erhöhten Risiko für die Entwicklung einer t-AML assoziiert sind (Seedhouse et al. 2004). Es wurde jedoch nicht dargestellt, welchen Effekt die Polymorphismen in Bezug auf die Funktion der zu codierenden Proteine haben. Hier ist es unsere Zielsetzung gewesen, diese Lücke zu verkleinern, indem wir zunächst die Möglichkeit der direkten funktionellen Messung der Reparaturkapazität in hämatopoetischen Zellen zeigen. Der Wirtszell-Reaktivierungs-Test bietet dafür 
besonders gute Möglichkeiten, da er nur die korrekt reparierte Menge der durch die Zellen reparierten Doppelstrangbrüche anzeigt.

\subsection{Wirtszell-Reaktivierungs-Test}

Der Wirtszell-Reaktivierungs-Test (HCR) ist ein einzigartiges Versuchssystem, welches die Möglichkeit der Analyse einzelner Reparatursysteme nach Einführung von definierten Schäden ermöglicht. Er wurde ursprünglich von Athas et al. entwickelt und nutzt das rekombinante Plasmid pCMVcat, welches für die Chloramphenicol-Acetyltransferase als Reportergen codiert (Athas et al. 1991). Qiao et al modifizierten dieses System mit dem effektiveren Luciferase-Reporterplasmid pCMVluc (Qiao et al. 2002b).

Beim Wirtszell-Reaktivierungs-Test gibt es zur Untersuchung der durch Restriktionsenzyme verursachten DSB zwei unterschiedliche methodische Ansätze. Eine Möglichkeit ist das Einbringen von Restriktionsenzymen in die Zelle. Vorteil ist die Beurteilbarkeit der Einflüsse der Umgebungsstruktur, großer Nachteil allerdings das nicht exakt vorhersagbare Verhalten der Restriktionsenzyme (Thacker 1994). Die alternative, in dieser Arbeit verwendete Methode ist das Einbringen von definierten DNA-Schäden, welche zuvor in exogene DNA (zum Beispiel Plasmide) eingefügt und via Transfektion in die Zelle eingebracht wurden (Athas et al. 1991). In diesem System wird die Transkription des Reportergens, welches durch die Reparaturmechanismen der Zelle wieder reaktiviert wird, gemessen. Vorteil dieser Methode ist, dass die DNA-Schäden vorher exakt definiert und beispielsweise mittels Gelelektrophorese von nicht veränderter DNA getrennt werden können. Nachteil bleibt eine Unsicherheit bezüglich der Einflüsse, die das Einbringen fremder DNA auf die Zellaktivität haben könnte.

In dieser Arbeit wurde der HCR-Test so modifiziert, dass er die Möglichkeit bietet, linearisiertes Plasmid in Leukämie- respektive primäre Blutzellen von Patienten einzubringen, um deren Reparaturkapazität zu untersuchen. Der „DNA-Defekt“ wird durch einen Schnitt im Luciferase-Gen simuliert, welcher durch ein Restriktionsenzym eingefügt wird. Nur durch einen funktionierenden DSBReparaturapparat in der Zelle lässt sich das Plasmid wieder so religieren, dass das 
pCMVluc -Gen korrekt abgelesen werden kann und die Luciferase exprimiert wird. Diese spaltet das im Überschuss zugegebene Luciferin, wobei die Lichtemission pro Zeit mit der gebildeten Luciferasemenge korreliert. Ein Vergleich zu unbehandeltem Kontrollplasmid ermöglicht den Rückschluss auf die Reparaturkapazität der Zelle.

Vorteile dieser Methode sind die direkte funktionelle Analyse und die Unabhängigkeit von indirekten genetischen Markern.

Da die Handhabung so optimiert wurde, dass der Wirtszell-Reaktivierungs-Test auch mit geringen Mengen schwer transfizierbarer Zellen auskommt, entspricht er den Ansprüchen von Wei Q et al., welche für ein gutes Testsystem ein einfach und zügig durchzuführendes, nicht radioaktives Procedere fordern, welches auch mit eingefrorenen Zellen funktioniert (Wei Q et al. 1993).
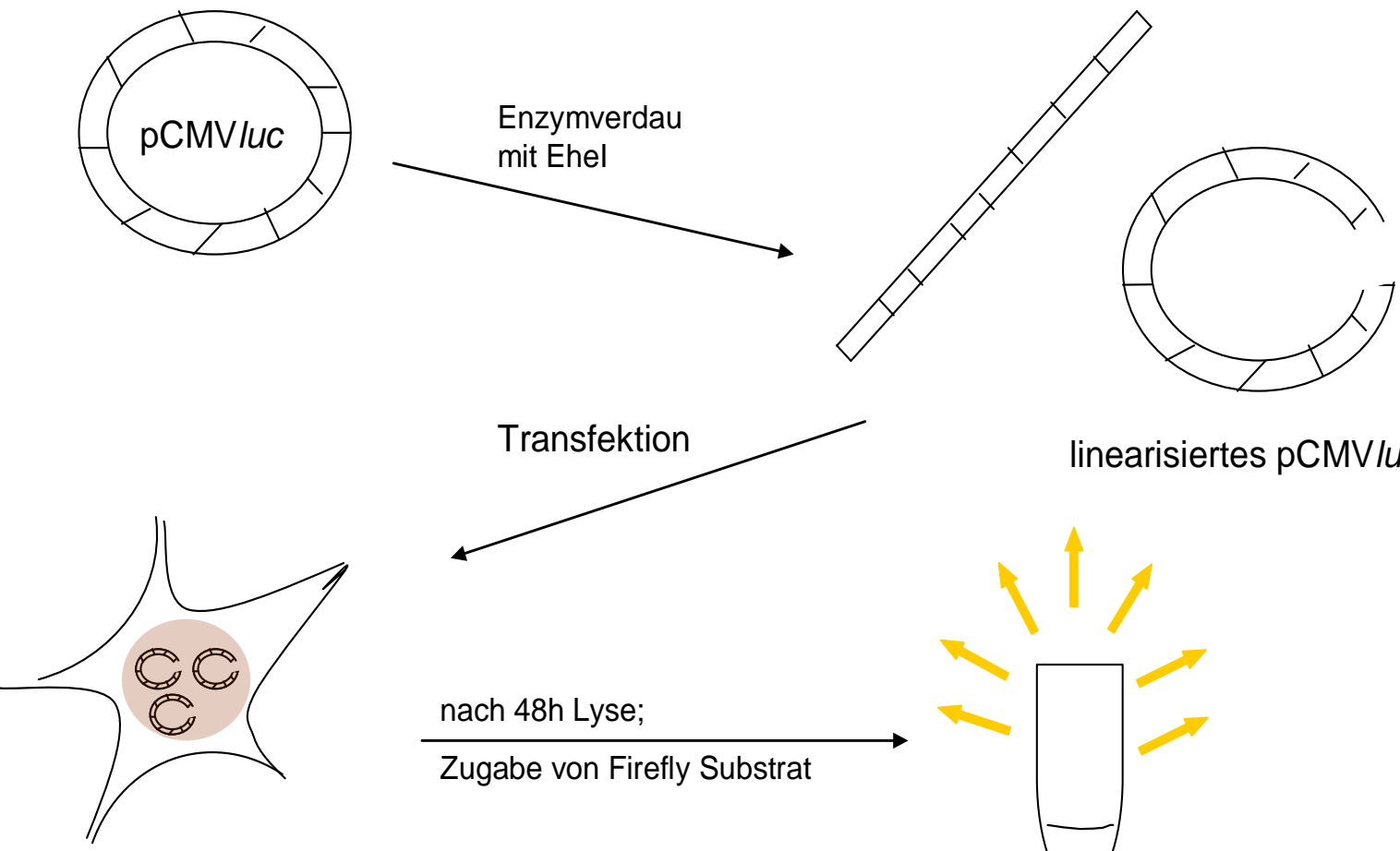

\section{linearisiertes pCMVluc}

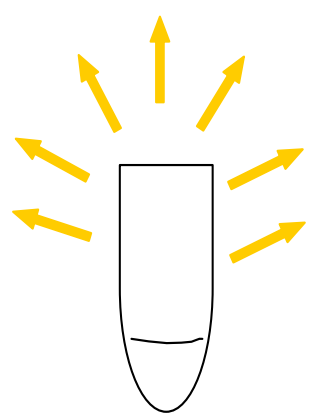

Abbildung 2: Schema des Wirtszell-Reaktivierungs-Test (nach Thoms et al. 2007 S.582)

Das Luciferase-Test-System ist ein in vielen verschiedenen Versuchsystemen etabliertes Nachweissystem, welches einfach zu handhaben ist und zuverlässig funktioniert (Qiao et al. 2002a; Thoms et al. 2007; Wang L et al. 2007). In unseren Versuchen wurden zwei verschiedene Luciferase-Reporter-Systeme verwendet: das 
Firefly-Luciferase-System zur Messung der korrekten Reparationskapazität und das Renilla-Luciferase-System als interne Kontrolle.

\subsubsection{Nachweis der Firefly-Luciferase-Reportergen-Aktivität}

Bei dem aus der nordamerikanischen Glühwürmchenart Photinus pyralis klonierten Luciferase-Enzym handelt es sich um ein $61 \mathrm{kDa}$ großes monomeres Protein, für dessen enzymatische Aktivität keine posttranslationale Modifikation nötig ist. Es kann unter ATP-Verbrauch und unter Anwesenheit von Magnesiumionen mit dem Substrat Luciferin komplexieren. Der entstandene Luciferase-Luciferyl-AMP-Komplex wird in einem zweiten Reaktionsschritt oxidativ decarboxyliert und zerfällt in Luciferase, Oxyluciferin, AMP, Pyrophosphat und $\mathrm{CO}_{2}$. Außerdem kommt es zur entscheidenden Lichtemission im Bereich von $560 \mathrm{~nm}$, die durch das Luminometer detektiert werden kann (de Wet et al. 1987). Da die zugegebene Luciferinmenge im Überschuss erfolgt, ist die Lichtemission proportional zur Enzymmenge in den Ansätzen.<smiles>CCCCOc1ccc2nc(C3=NC(=O)CS3)sc2c1</smiles>

Abbildung 3: Mechanismus der Lichtemission durch die Firefly-Luciferin-Luciferasereaktion (nach Aflalo 1991 S.283): LH2, Luciferin; ATP, Adenosintriphosphat; PPi, Pyrophosphat; $\mathrm{H}^{+}$, Proton; $\mathrm{O}_{2}$, Sauerstoff, $\mathrm{CO}_{2}$, Kohlenstoffdioxid; *, elektronisch angeregter Zustand; hv, Lichtemission 


\subsubsection{Nachweis der Renilla- Luciferase-Reportergen-Aktivität}

Das $36 \mathrm{kDa}$ große Renilla-Luciferase-Enzym ist wie das Firefly-Enzym monomer und benötigt ebenfalls keine posttranslationale Modifikation. Das Gen stammt ursprünglich von der Korallenart Renilla reniformis, wurde allerdings in einigen Basen bei konstantem Phänotyp verändert, sodass weniger Restriktionsendonukleasen angreifen können. Sowohl Plasmid als auch Substrat wurden von der Firma Promega bezogen.

Alle gemessenen Werte für die Firefly-Luciferase-Aktivität wurden gegen die entsprechenden Werte der Renilla-Luciferase als interne Kontrolle normalisiert.

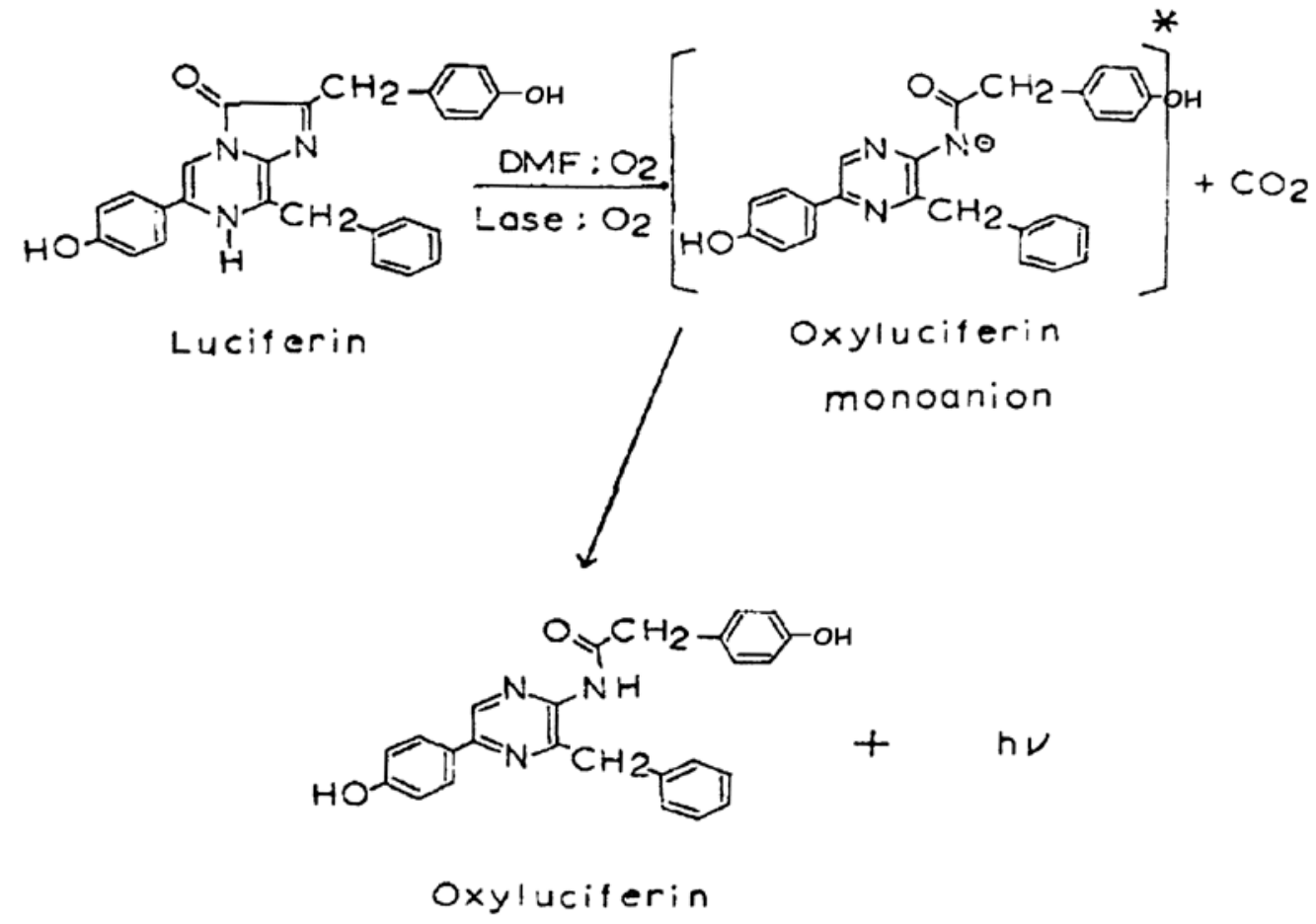

Abbildung 4: Mechanismus der Lichtemission mit Renillaluciferin (modifiziert nach Hori et al. 1973 S.4467): DMF, Dimethylformamid; $\mathrm{O}_{2}$, Sauerstoff; Lase, Luciferase; $\mathrm{CO}_{2}$, Kohlenstoffdioxid; *, elektronisch angeregter Zustand; hv, Lichtemission 


\section{Material und Methoden}

\subsection{Materialien}

\subsubsection{Zelllinien}

Tabelle 3: Beschreibung und Kultivierungsbedingungen der verwendeten Zelllinien: $\mathrm{CO}_{2}$ Kohlenstoffdioxid, EBV Epstein-Barr-Virus, FCS fetal calf serum (fetales Kälberserum), IMDM Iscove's Modified Dulbecco's Medium, RPMI Roswell Park Memorial Institute Kulturmedium,

\begin{tabular}{|c|c|c|c|c|}
\hline Zelllinie & Art & Quelle & Medium und Zusätze & $\begin{array}{l}\text { Kultur- } \\
\text { bedingung }\end{array}$ \\
\hline AG 10107 & $\begin{array}{l}\text { B-Lympho- } \\
\text { zyten mit EBV } \\
\text { transformiert }\end{array}$ & $\begin{array}{l}\text { Coriell Cell } \\
\text { Repositories, } \\
\text { Camden, NJ, } \\
\text { USA }\end{array}$ & $\begin{array}{l}\text { IMDM } \\
\text { 20\% FCS } \\
\text { hitzeinaktiviert } \\
\text { Penicillin/ } \\
\text { Streptomycin } \\
\text { Glutamin }\end{array}$ & $\begin{array}{l}37^{\circ} \mathrm{C} \\
7,6 \% \mathrm{CO}_{2}\end{array}$ \\
\hline GM 03715 & $\begin{array}{l}\text { B-Lympho- } \\
\text { zyten mit EBV } \\
\text { transformiert }\end{array}$ & $\begin{array}{l}\text { Coriell Cell } \\
\text { Repositories, } \\
\text { Camden, NJ, } \\
\text { USA }\end{array}$ & $\begin{array}{l}\text { IMDM } \\
\text { 15\% FCS nicht } \\
\text { hitzeinaktiviert } \\
\text { Penicillin/ } \\
\text { Streptomycin } \\
\text { Glutamin }\end{array}$ & $\begin{array}{l}37^{\circ} \mathrm{C} \\
7,6 \% \mathrm{CO}_{2}\end{array}$ \\
\hline SU-DHL-4 & $\begin{array}{l}\text { B-Zell- } \\
\text { Lymphom }\end{array}$ & $\begin{array}{l}\text { DSMZ No. ACC } \\
495\end{array}$ & \multirow{4}{*}{$\begin{array}{l}\text { RPMI, } \\
\text { 10\% FCS } \\
\text { hitzeinaktiviert, } \\
\text { Penicillin/ } \\
\text { Streptomycin, } \\
\text { Amphotericin }\end{array}$} & \multirow{4}{*}{$\begin{array}{l}37^{\circ} \mathrm{C} \\
5 \% \mathrm{CO}_{2}\end{array}$} \\
\hline Kasumi-1 & AML & $\begin{array}{l}\text { DSMZ No. ACC } \\
220\end{array}$ & & \\
\hline K 562 & $\begin{array}{l}\text { CML in } \\
\text { Blastenkrise }\end{array}$ & $\begin{array}{l}\text { DSMZ No. ACC } \\
10\end{array}$ & & \\
\hline CCRF-CEM & $\begin{array}{l}\text { T-Zell akute } \\
\text { lymphatische } \\
\text { Leukämie }\end{array}$ & $\begin{array}{l}\text { DSMZ No. ACC } \\
240\end{array}$ & & \\
\hline
\end{tabular}




\subsubsection{Bakterienstämme}

Für die Amplifikation des Plasmids sowie den Nachweis der Religation wurden zwei

E. coli - Stämme verwendet.

E. coli Genotyp DH5a:

$\mathrm{F}^{-}$(Ф80d/acZAM15), recA1, endA1, gyrA96, thi-1, hsdR17( $\left.\mathrm{r}_{\mathrm{k}}{ }^{-}, \mathrm{m}_{\mathrm{k}}{ }^{+}\right)$, supE44, relA1, deoR, $\triangle($ lacZYA-argF)U169, phoA

E. coli MLB100 (MBM7070):

F-lacZ (am)CA7020, lacY1, hsdR-, hsdM+, araD139 $\triangle($ araABC-leu $) 7679$, galU, galK, rpsL, thi

\subsubsection{Plasmide}

Tabelle 4: Liste der verwendeten Plasmide

\begin{tabular}{|l|l|l|l|l|l|}
\hline $\begin{array}{l}\text { Plasmid- } \\
\text { name }\end{array}$ & Beschreibung & Vektor & Referenz & $\begin{array}{l}\text { Plasmid- } \\
\text { größe }\end{array}$ & Resistenz \\
\hline pRL-CMV & $\begin{array}{l}\text { Renilla } \\
\text { Luciferase mit } \\
\text { CMV-Promotor }\end{array}$ & pRL & $\begin{array}{l}\text { Promega } \\
\text { (Mann- } \\
\text { heim) }\end{array}$ & $4079 \mathrm{kB}$ & Ampicillin \\
\hline pCMVluc & $\begin{array}{l}\text { Firefly } \\
\text { Luciferase mit } \\
\text { CMV-Promotor }\end{array}$ & pGL3 & $\begin{array}{l}\text { Emmert et } \\
\text { al 2002, } \\
\text { Qiao et al. } \\
2002 a\end{array}$ & $4863 \mathrm{kB}$ & Ampicillin \\
\hline
\end{tabular}




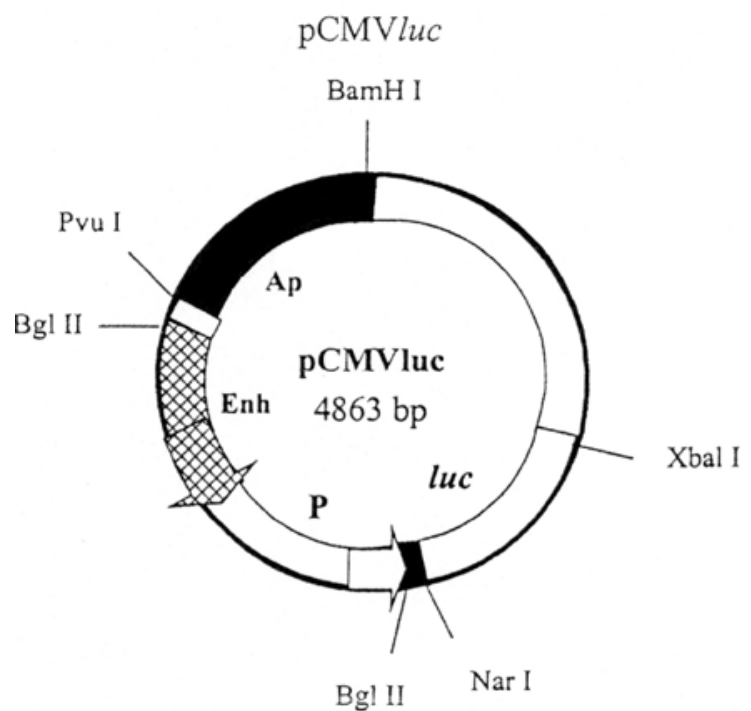

Abbildung 5: Plasmidkarte pCMVluc (aus Qiao et al. 2002a S.167): Ap, Ampicillingen; bp, Basenpaare; CMV, Zytomegalievirus; Enh, Enhancer; P, Promoter; alle anderen Abkürzungen signalisieren Enzymschnittstellen

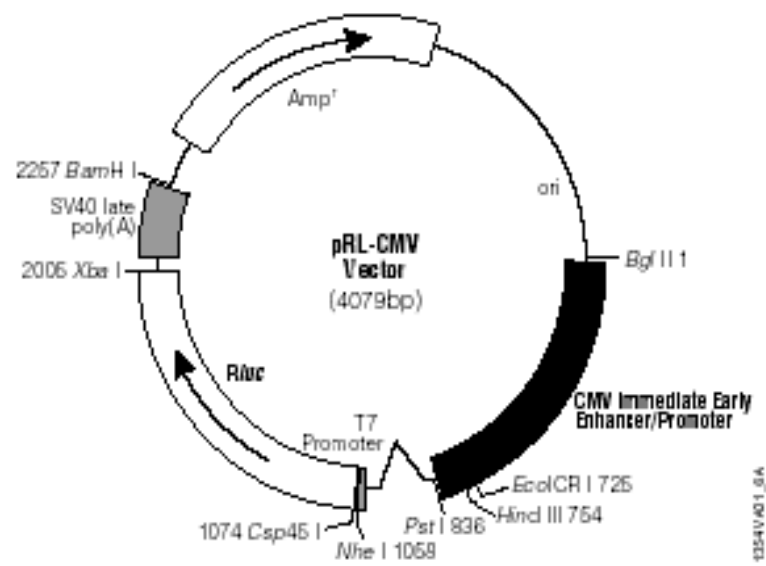

Abbildung 6: Plasmidkarte pRL-CMV (Promega 2006 S.201): Amp, Ampicillingen, bp, Basenpaare; $\mathrm{CMV}$, Zytalomegalievirus; Rluc, Renillaluciferasegen; alle anderen Abkürzungen signalisieren Enzymschnittstellen 


\subsection{Kryokonservierung von Zellen}

Um Zellen für spätere Versuche aufzubewahren, wurden sie in Kryoröhrchen verteilt und in flüssigem Stickstoff gelagert. Pro Kryoröhrchen wurden maximal $10^{7}$ Suspensions-Zellen eingefroren. Dazu wurde die Zellzahl bestimmt (siehe 2.4) und die Kultur bei 1200 rpm und Raumtemperatur 10 min abzentrifugiert. Das Pellet wurde nach Verwerfen des Überstands in $0,5 \mathrm{ml}$ frischem Medium pro Kryoröhrchen gelöst und in die Kryoröhrchen aliquotiert. Nach Zugabe von je 0,5 ml Einfriermedium erfolgte sofort die Lagerung auf Eis. Anschließend wurden die Röhrchen in einer Kryobox (Nalge Nunc International, Wiesbaden), bei $80^{\circ} \mathrm{C}$ (MDF-U72V Ultratiefkühlschrank, Sanyo, Bad Nenndorf) eingefroren und nach mindestens $24 \mathrm{~h}$ in flüssigem Stickstoff (Biosafe ${ }^{\circledR}$, Messer Griesheim, Sulzbach) gelagert.

\section{Einfriermedium:}

$\begin{array}{lll}20 \% & \text { DMSO } & \text { (Dimethylsulfoxid, Merck, Darmstadt) } \\ 60 \% & \text { FCS } & \text { (fetal calf serum, Biochrom, Berlin) } \\ 20 \% & \text { frisches Medium } & \text { (je nach Zelllinie, siehe } 2.1 .1 \text { ) }\end{array}$

\subsection{Auftauen von Zellen}

Die für die Versuche benötigten Zelllinien waren bei $-196^{\circ} \mathrm{C}$ in flüssigem Stickstoff kryokonserviert. Zum Kultivieren mussten sie aufgetaut werden. Dazu wurde ein Kryoröhrchen (greiner bio-one, Solingen) mit den jeweiligen Zellen unter fließendem Wasser leicht angetaut und sofort in $10 \mathrm{ml}$ Medium aufgenommen. Nach dem Zentrifugieren bei $1200 \mathrm{rpm}$ und Raumtemperatur für $10 \mathrm{~min}$ (Megafuge 1.0R, Heraeus Sepratech, Göttingen) wurde der Überstand abgesaugt und das Pellet in 3$5 \mathrm{ml}$ Medium resuspendiert, um es in eine $50 \mathrm{ml}$ bzw. $250 \mathrm{ml}$ Gewebekulturflasche (greiner bio-one, Solingen) aufzunehmen. Medium und Brutschrank variierten je nach Zelllinie (siehe 2.1.1). 


\subsection{Bestimmung der Zellzahl}

Für verschiedene Methoden, unter anderem Transfektion und Kryokonservierung der Zellen, war es wichtig die genaue Zellzahl zu kennen. Gleichzeitig erfolgte immer eine Vitalfärbung mittels Trypanblau (Sigma-Aldrich, Steinheim).

Trypanblau dringt in die Zellen ein, kann jedoch nur von vitalen Zellen wieder hinaustransportiert werden. Dadurch bleiben sie hell, während die toten Zellen im Mikroskop bläulich erscheinen.

Zum Zählen wurde die Zellsuspension mit der Pipette gut durchmischt und das Volumen ermittelt. Dann wurden $30 \mu$ der Suspension mit $30 \mu$ Trypanblau versetzt.

Es wurde eine Neubauer-Zählkammer (Neubauer improved, Brand, Wertheim) verwendet. Unter 10-facher Vergrößerung (Axiovert 100 Mikroskop, Zeiss, Jena) ergab sich folgender Algorithmus für die Berechnung der Zellzahl (Konzentration):

Konzentration [Zellen/ml] $=$ Mittelwert der vier großen Kammern * Verdünnung *10 4

$=($ Gesamtzellzahl der vier Kammern / 4$) * 2 * 10^{4}$

\subsection{Mediumwechsel}

Meist erfolgte der Mediumwechsel nur partiell. Die Kulturflaschen wurden zunächst aufrecht gestellt, um die Zellen sedimentieren zu lassen. Anschließend wurde das verbrauchte Medium etwa zur Hälfte abgesaugt und mit frischem Medium wieder aufgefüllt. Ein kompletter Mediumwechsel wurde nur bei zu geringer Zelldichte oder bei großen Mengen an toten Zellen (letzteres mit Ficoll-Gradient, siehe 2.6) durchgeführt. Dazu wurde die Zellsuspension bei 1000 rpm und Raumtemperatur 8 min abzentrifugiert, der Überstand abgesaugt und das Pellet in frischem Medium aufgenommen.

\subsection{Ficoll-Gradient zum Waschen der Zellen}

Um die vitalen Zellen von großen Mengen Detritus zu befreien, wurde die Kultur nach Abzentrifugation der Zellsuspension bei 1000 rpm und Raumtemperatur für 8 min 
und der Aufnahme des Pellets in 1-2 ml Medium vorsichtig auf $6 \mathrm{ml}$ Ficoll-Lösung (PAA-Laboratories, Pasching, Österreich) geschichtet und bei 1500 rpm und Raumtemperatur für 10 min zentrifugiert. Wichtig ist hierbei die Raumtemperatur, damit die Ficoll-Lösung die optimale Dichte aufweist. Nur so können tote Zellen und Zellreste sedimentieren, während vitale Lymphozyten im oberen Teil hängen bleiben. Der obere Teil des Gradienten konnte in $5 \mathrm{ml}$ Medium überführt werden. Dann wurde erneut für 8 min bei 1000 rpm und Raumtemperatur zentrifugiert. Das Pellet wurde wieder in Kultur gebracht.

\subsection{Isolierung der mononukleären Zellen aus Patientenblut mittels Ficoll- Gradienten}

Aus den Blutproben ließen sich mittels Ficoll-Gradient die mononukleären Zellen isolieren. Dazu wird die Blutprobe in einem Falcon-Röhrchen im Verhältnis 1:1 mit PBS versetzt und mit $10 \mathrm{ml}$ Ficoll-Lösung unterschichtet. Nach Zentrifugation bei 2400 rpm für 20 min ohne Bremse wurde mit einer Pasteurpipette die Zellschicht vorsichtig absaugt und in ein neues Falcon-Röhrchen gegeben. Dann wurde erneut mit 20 ml PBS gewaschen und bei 1700 rpm 10 min abzentrifugiert. Nach Absaugen und Lösen in $10 \mathrm{ml}$ PBS konnte die Zellzahl bestimmt und die isolierten mononukleären Zellen in Kultur genommen bzw. eingefroren werden.

\section{1 x PBS (phosphate buffered saline), pH 7,0:}

$\begin{array}{lll}4 \mathrm{~g} & \mathrm{NaCl} & \text { (Merck, Darmstadt) } \\ 0,1 \mathrm{~g} & \mathrm{KCl} & \text { (Merck) } \\ 0,72 \mathrm{~g} & \mathrm{Na}_{2} \mathrm{HPO}_{4} \times 2 \mathrm{H}_{2} \mathrm{O} & \text { (Roth, Karlsruhe) } \\ 0,1 \mathrm{~g} & \mathrm{KH}_{2} \mathrm{PO}_{4} & \text { (Merck) }\end{array}$

ad $500 \mathrm{ml}$ Aqua bidest., autoklaviert

\subsection{DAPI-Test auf Mykoplasmen}

Bei Kontaminationen der Zellkultur mit Mykoplasmen besteht die Gefahr, dass dies die Stoffwechselleistung der Zellen beeinträchtigt. Um einen Befall auszuschließen, wurde der DAPI-Test durchgeführt. Das Prinzip des Tests beruht auf der Komplexbildung von DAPI (4,6-Diamidinophenylindol) mit doppelsträngiger DNA. 
Diese Komplexe erscheinen unter UV-Licht als blau leuchtende Punkte und stellen die im Zytoplasma befindliche Mykoplasmen-DNA dar.

Es wurden $5 \mathrm{ml}$ Zellsuspension in ein Falcon-Röhrchen pipettiert und bei 1000 rpm und Raumtemperatur für 7 min zentrifugiert. Anschließend wurde das Pellet zwei Mal mit $1 \mathrm{ml}$ PBS gewaschen (die Zentrifugation erfolgte bei $1000 \mathrm{rpm}$ und Raumtemperatur für $5 \mathrm{~min}$ ). Dann wurden die Zellen in $100 \mu \mathrm{l}$ PBS und $1 \mathrm{ml}$ DAPI (Sigma-Aldrich, Steinheim) in Methanol (Merck, Darmstadt) für 15 min im Dunkeln stehen gelassen, da der Fluoreszenzfarbstoff lichtempfindlich ist. Die Konzentration des DAPI in Methanol betrug 0,1 mg/ml. Nach weiteren zwei Waschgängen mit PBS wurde das Pellet in $100 \mu \mathrm{l}$ PBS aufgenommen, auf einen Objektträger getropft und mit einem Deckglas fixiert. Unter dem Fluoreszenzmikroskop (Zeiss, Jena) in 100x Vergrößerung in Immersionsöl zeigten sich die Mykoplasmen-DNA als kleine, leuchtende Punkte oder Ansammlungen. Befallene Kulturen wurden konsequent entsorgt.

\subsection{Transfektion mit DEAE-Dextran}

Bei der Transfektion wird fremde DNA in Form eines Vektors in die eukaryotische Zelle eingeschleust, um die Gene, die auf dem Vektor liegen, exprimieren zu lassen. Dadurch kann die Zelle neue Eigenschaften zeigen. Man unterscheidet stabile (wobei die DNA in das Wirtsgenom eingebaut wird) und transiente Transfektionen (dabei bleibt die Fremd-DNA nur zeitweise in der Wirtszelle) (Sambrook und Russell 2001).

Die transienten Transfektionen wurden mit Hilfe von DEAE-Dextran (Diethylaminoethyldextran) durchgeführt. DEAE-Dextran ist ein kationisch geladenes Polymer, welches in den verwendeten Konzentrationen nicht toxisch ist (Fregeau und Bleackley 1991). Dabei wird vermutlich der Vektor mittels Endozytose aufgenommen und in den Nukleus gebracht (Sambrook und Russell 2001). Als Reporterplasmid wurde pCMVluc eingesetzt und pRL-CMV zur Kontrolle der Ligationseffizienz kotransfiziert.

Die verwendete Zellzahl sowie die verwendete Plasmidmenge variierte je nach Zelllinie und wurde mittels Titrations-Versuch ermittelt. Alle Ansätze wurden durch Auffüllen mit STBS auf $100 \mu$ l gebracht. Ein zusätzlicher Leerversuch ohne Plasmid 
erfolgte standardmäßig. Alle Versuche wurden mit dreifachem Ansatz durchgeführt und die gemessenen Werte anschließend gemittelt.

Zuerst wurde die Zellsuspension gut durchmischt und die Zellzahl bestimmt (siehe 2.4). Anschließend wurde die benötigte Zellmenge im Falcon-Röhrchen bei 1200 rpm und Raumtemperatur für 10 min abzentrifugiert. Der Überstand aus konditioniertem Medium wurde abgegossen und aufbewahrt. Anschließend erfolgte ein Waschschritt mit 10 ml PBS. Das PBS wurde nach der Zentrifugation (1200 rpm, Raumtemperatur, 10 min) abgesaugt und das Pellet in $150 \mu \mathrm{l}$ STBS pro Ansatz resuspendiert. Diese $150 \mu \mathrm{l}$ wurden dann in Polystyrenröhrchen (Becton Dickinson Labware Europe, Meylan Cedex, Frankreich) pipettiert, welche die vorbereiteten Ansätze aus $25 \mu \mathrm{g}$ DEAE-Dextran, den jeweiligen Plasmidmengen bzw. Aqua bidestilliert und STBS enthielten. Die Ansätze wurden vorsichtig durchmischt und nach 15-minütiger Inkubation im Brutschrank mit je $2 \mathrm{ml}$ konditioniertem Medium abgestoppt. Das Zellpellet, das nach erneutem Abzentrifugieren (bei 1200 rpm und Raumtemperatur $10 \mathrm{~min}$ ) entstand, wurde in $4 \mathrm{ml}$ gemischtem Medium (aus je $2 \mathrm{ml}$ frischem und $2 \mathrm{ml}$ konditioniertem Medium) resuspendiert und die transfizierte Kultur für 48 Stunden im Brutschrank inkubiert.

$48 \mathrm{~h}$ nach Transfektion erfolgte die Ernte der Zellen. Dazu wurde nach Zentrifugation bei 1200 rpm und Raumtemperatur für 10 min der Überstand abgesaugt und das Pellet mit 2 ml PBS gewaschen. Nach erneutem Abzentrifugieren und Entfernen des Überstandes wurden die Zellen mit $100 \mu \mathrm{l}$ PLB (Promega, Mannheim) je Ansatz lysiert.

Durch das Luciferase-Test-System der Firma Promega ließ sich die Aktivität des Luciferase-Enzyms nachweisen. Der Luciferase-Test-Puffer sowie das LuciferaseTest-Substrat wurden nach Angaben des Herstellers gemischt.

Für die Messung wurden $80 \mu \mathrm{l}$ der geernteten Ansätze in Luminometer-Röhrchen pipettiert. Das Luminometer (AutoLumat LB 953, E\&G Berthold, Wildbach) injizierte automatisch $200 \mu$ des Substrates zu jedem Ansatz. Die Messung des Leerwertes für jeden Ansatz sowie die Lichtemission über 20 sek wurden ebenfalls automatisch vom Gerät dargestellt. Aufgrund der im Überschuss zugegeben Luciferinmenge ist die Lichtemission proportional der Enzymmenge. 


STBS (suspension tris buffered saline) - Lösung
$\begin{array}{cl}25 \mathrm{mM} \text { Tris HCl, pH 7,4 } & \text { (Merck, Darmstadt) } \\ 137 \mathrm{mM} \mathrm{NaCl} & \text { (Merck) } \\ 5 \mathrm{mM} \mathrm{KCl} & \text { (Merck) } \\ 0,7 \mathrm{mM} \mathrm{CaCl}_{2} & \text { (Merck) } \\ 0,5 \mathrm{mM} \mathrm{MgCl}_{2} \times 6 \mathrm{H}_{2} \mathrm{O} & \text { (Merck) } \\ 0,6 \mathrm{mM} \mathrm{Na}_{2} \mathrm{HPO}_{4} & \text { (Merck) } \\ \rightarrow \text { steril filtriert } & \end{array}$

\subsection{Herstellung kompetenter Bakterienstämme}

Unter normalen Umständen ist die Zellwand von Bakterien undurchlässig für fremde DNA. Durch Behandlung mit Kalziumchlorid wird jedoch die Aufnahme von FremdDNA möglich (Mandel und Higa 1970). Für die Transformation durch Elektroporation wurde die Zelloberfläche durch Glycerin modifiziert.

\subsubsection{Herstellung kompetenter Bakterienstämme für die Hitzeschocktransformation}

Zur Herstellung der kompetenten E.coli-Stämme wurden LB (lysogeny broth)Medium aus Lennox L Broth Base Powder (invitrogen, Karlsruhe) nach Herstellerangaben angefertigt und $5 \mathrm{ml}$ LB-Medium mit einer Kolonie E.coli Genotyp $\mathrm{DH} 5 \alpha$ beimpft. Diese Impfkultur wurde über Nacht bei $37^{\circ} \mathrm{C}$ im Schüttler (Ifors $A G$, Bottmingen, Schweiz) inkubiert. Davon wurden $100 \mu \mathrm{l}$ in $50 \mathrm{ml}$ TyM-Medium überführt, um es weiter zu inkubieren, bis das Medium trüb war (ca. $2 \mathrm{~h}$ ). Anschließend wurden aus der zweiten Kultur $2 \mathrm{ml}$ in $200 \mathrm{ml}$ TyM-Medium überführt. Um die Zellen in der optimalen Wachstumsphase zu verwenden, wurde in regelmäßigen Abständen im Spektrophotometer (DU ${ }^{\circledR} 640$, Beckmann, USA) die optische Dichte bei $600 \mathrm{~nm}$ gemessen. Ab einer OD $_{600 \mathrm{~nm}}$ Zwischen 0,6-0,8 wurde der Ansatz in 4 Falcons à $50 \mathrm{ml}$ bei $4^{\circ} \mathrm{C}$ unter $3000 \mathrm{rpm} 10 \mathrm{~min}$ (Megafuge 1.0R Heraeus, Göttingen) abzentrifugiert, der Überstand verworfen, das Pellet in je $20 \mathrm{ml}$ Transformationspuffer I resuspendiert und für 20 min auf Eis inkubiert. Nach erneuter 
Zentrifugation bei $4^{\circ} \mathrm{C}$ und $2400 \mathrm{rpm}$ für 10 min wurde das Pellet langsam in je $4 \mathrm{ml}$ Transformationspuffer II gelöst. Die Lagerung der nun kompetenten Zellen erfolgte bei $-80^{\circ} \mathrm{C}$.

TyM, pH 7,0

$\begin{array}{rll}10 \mathrm{~g} & 2 \% \text { Budo Tryptone } & \text { (Difco, Detroit, MI, USA) } \\ 2,5 \mathrm{~g} & 0,5 \% \text { Budo Yeast Extract } & \text { (Difco) } \\ 2,92 \mathrm{~g} & \mathrm{NaCl} & \text { (Merck, Darmstadt) } \\ 1,015 \mathrm{~g} & \mathrm{MgCl}_{2} \times 7 \mathrm{H}_{2} \mathrm{O} & \text { (Merck) } \\ & \text { ad } 500 \mathrm{ml} \text { Aqua bidest., autoklaviert }\end{array}$

Transformationspuffer I, pH 7,0

$\begin{array}{rll}0,58 \mathrm{~g} & 30 \mathrm{mM} \mathrm{K}-\mathrm{Acetat} & \text { (Merck, Darmstadt) } \\ 2,04 \mathrm{~g} & 50 \mathrm{mM} \mathrm{MgCl} \times 7 \mathrm{H}_{2} \mathrm{O} & \text { (Merck) } \\ 1,5 \mathrm{~g} & 100 \mathrm{mM} \mathrm{KCl} & \text { (Merck) } \\ 0,294 \mathrm{~g} & 10 \mathrm{mM} \mathrm{CaCl}_{2} \times 2 \mathrm{H}_{2} \mathrm{O} & \text { (Merck) } \\ 60,02 \mathrm{~g} & 15 \% \mathrm{Glycerol}(99 \% \mathrm{ig}) & \text { (Sigma-Aldrich, Steinheim) } \\ & \text { ad 200 ml Aqua bidest., autoklaviert }\end{array}$

Transformationspuffer II, pH 7,0
$0,23 \mathrm{~g} 10 \mathrm{mM}$ MOPS
(Roth, Karlsruhe)
1, $12 \mathrm{~g} 75 \mathrm{mM} \mathrm{CaCl}_{2}$
(Merck)
$0,07 \mathrm{~g} \quad 10 \mathrm{mM} \mathrm{KCl}$
(Merck)
30, $01 \mathrm{~g}$ 15\% Glycerol (99\%ig)
(Sigma-Aldrich, Steinheim) ad 100 ml Aqua bidest., autoklaviert

\subsubsection{Herstellung kompetenter Bakterienstämme für die Elektroporation}

Das Herstellen von kompetenten Bakterien für die Elektroporation wurde in Anlehnung an die Methode von Hanahan durchgeführt (Hanahan 1983). Nach Animpfen einer Übernachtkultur mit E.coli-Stamm MLB100 wurden am nächsten Tag eine Vor- und anschließend eine Hauptkultur herangezogen. Ab einer $O D_{600 n m}$ zwischen 0,6 und 0,8 wurde die Kultur bei $4^{\circ} \mathrm{C}$ für $20 \mathrm{~min}$ bei $2300 \mathrm{rpm}$ zentrifugiert. Alle folgenden Schritte wurden auf Eis durchgeführt. Das Pellet wurde einmal mit 50 
$\mathrm{ml}$ und anschließend mit $25 \mathrm{ml}$ kaltem Aqua bidestilliert gewaschen. Nach einer weiteren Zentrifugation für 15 min wurde das Pellet in 20 ml eiskaltem Glycerol (10 \% $\mathrm{v} / \mathrm{v}$ ) aufgenommen. Es folgte ein erneutes Abzentrifugieren (2300 rpm, $4^{\circ} \mathrm{C}, 20 \mathrm{~min}$ ), anschließend wurden die kompetenten Zellen in $2 \mathrm{ml}$ Glycerol aufgenommen und aliquotiert. Die Lagerung erfolgte bei $-80^{\circ} \mathrm{C}$.

\subsection{Transformation}

Der Begriff Transformation bezeichnet allgemein die Veränderung der Gestalt, Form oder Struktur in eine andere ohne Verlust der Substanz. In der Molekularbiologie bezeichnet es konkret die Aufnahme von freier DNA durch Zellen.

Bakterien, die durch Transformation ein Plasmid aufgenommen haben und seine Information exprimieren, sind aufgrund eines Antibiotikaresistenzgens auf dem Plasmid gegenüber diesem Antibiotikum unempfindlich. Bringt man nun die Bakterien auf eine Agarplatte aus, die das spezifische Antibiotikum enthält, so können plasmidtragende Bakterien selektioniert werden. Diese Bakterien replizieren das Plasmid, sodass später für die entsprechenden Versuche größere Mengen isoliert werden können. Außerdem lässt sich die Effizienz der Ligation (siehe 2.17) überprüfen, da nur die Bakterien das Resistenzgen exprimieren, die ein geschlossenes Plasmid enthalten.

Für die Amplifizierung der Plasmide wurde die Elektroporationsmethode verwendet; zur Kontrolle der Ligation die Hitzeschocktransformation.

\subsubsection{Hitzeschocktransformation}

$200 \mu$ l kompetente E.coli- Zellen Genotyp DH5a wurden auf Eis aufgetaut und nach Zugabe von bis zu 50 ng Plasmid ebenfalls auf Eis inkubiert. Nach einer Minute bei $42^{\circ} \mathrm{C}$ wurde der Ansatz wieder für 3 min auf Eis gestellt. Abschließend wurden 80 $100 \mu \mathrm{l}$ auf LB-Platten, die mit $100 \mu \mathrm{l} / \mathrm{ml}$ Ampicillin versetzt waren, ausgestrichen und über Nacht bei $37^{\circ} \mathrm{C}$ inkubiert. 


\subsubsection{Elektroporation}

$80 \mu$ kompetente E.coli- Zellen Genotyp MLB100 wurden auf Eis aufgetaut. Dazu wurden $2 \mu \mathrm{l}$ Plasmid (etwa $100 \mathrm{ng}$ ) gegeben und der Ansatz in eine vorgekühlte Elektrodenküvette pipettiert. Die Elektroporation erfolgte bei 2,5 $\mathrm{V}$ und $600 \Omega$. Direkt danach wurde der Ansatz in $920 \mathrm{ml}$ LB-Medium aufgenommen und für $1 \mathrm{~h}$ im Schüttler inkubiert und je $100 \mu \mathrm{l}$ auf einer mit Ampicillin versetzten Agarplatte ausgestrichen.

\subsection{Herstellung von Agarplatten}

Zur Herstellung von Nährböden für die Bakterienkulturen wurde LB-Medium mit 15 g/l Agar versetzt und für 35 min autoklaviert (Bioclav, Schütt, Göttingen). Nach Abkühlung im Wasserbad auf $50{ }^{\circ} \mathrm{C}$ wurde unter der Sterilbank die Lösung mit 100 $\mu \mathrm{g} / \mathrm{ml}$ Ampicillin versetzt und in Petrischalen (greiner bio-one, Solingen) gegossen. Die erkalteten, festen Agarplatten wurden bis zur Verwendung bei $4{ }^{\circ} \mathrm{C}$ gelagert.

Ampicillin-Stocklösung: $\quad 50 \mathrm{mg} / \mathrm{ml} \mathrm{Na-Salz} \mathrm{(von} \mathrm{Boehringer,} \mathrm{Ingelheim} \mathrm{am} \mathrm{Rhein)}$ in Aqua bidest., sterilfiltriert

\subsection{Aufreinigung von Plasmid-DNA (Midi Prep)}

Zur Amplifikation der für die Versuche benötigten Plasmide wurden kompetente Bakterienkulturen mittels Elektroporation angeimpft und über Nacht bei $37^{\circ} \mathrm{C}$ im Schüttelinkubator kultiviert (siehe 2.11.2). Anschließend wurden die Plasmide mit Hilfe des QIAGEN Plasmid Midi Kits (QIAGEN, Hilden) nach Angaben des Herstellers aufgereinigt. Die Aufreinigung beruht auf dem Prinzip der AnionenAustauschchromatographie. Dazu befindet sich auf Säulen ein bestimmtes Material, das im sauren Milieu positiv geladene Gruppen enthält. Das Gegenion der Säulenmatrix kann bei geringen Salzkonzentrationen gegen die ebenfalls negativ geladene DNA ausgetauscht werden. Die DNA ist danach an die Säule gebunden. Nach Waschen der Säule kann die DNA wieder mit einem Puffer höherer 
Salzkonzentration eluiert werden. Die anschließende Isopropanolfällung dient zum Entfernen der Salze.

Anschließend wurde die DNA in EB-Puffer aufgenommen und die Konzentration sowie die Reinheit photometrisch bestimmt (siehe 2.15).

Puffer EB (elution buffer, Qiagen, Hilden): 10 mM Tris-Cl, pH 8.5

\subsection{Präzipitation von DNA mit Ethanol}

Die Fällung von DNA erfolgte nach Auffüllen des Volumens durch Aqua bidest. auf $100 \mu \mathrm{l}$. Nach Zugabe von $250 \mu \mathrm{l}$ reinem Ethanol (Merck, Darmstadt) und $10 \mu \mathrm{l}$ 3M Natriumacetat (Merck, Darmstadt) wurde im Eppendorfcup abzentrifugiert (20 Minuten, $13500 \mathrm{rpm}$ ), mit $70 \%$ igem Ethanol gewaschen, bei $45^{\circ} \mathrm{C}$ im Thermomixer getrocknet und in Aqua bidest. gelöst.

\subsection{Konzentrationsbestimmung von Nukleinsäuren}

Die Konzentration an Nukleinsäuren wurde photometrisch bei einer Wellenlänge von $260 \mathrm{~nm}$ bestimmt. In diesem Bereich liegt das Absorptionsmaximum von Nukleinsäuren. Bei einer Schichtdicke der Küvette von $1 \mathrm{~cm}$ entsprechen $50 \mu \mathrm{g}$ doppelsträngiger DNA der optischen Dichte $\mathrm{OD}_{260}$ von 1 (Sambrook und Russell 2001). Verunreinigungen mit Proteinen wurden durch eine zweite Messung bei 280 $\mathrm{nm}$ nachgewiesen, da die aromatischen Aminosäuren wie Tyrosin und Tryptophan bei dieser Wellenlänge ihr Absorptionsmaximum besitzen. Der Quotient $O D_{260} / O D_{280}$ liegt bei einer proteinfreien Nukleinsäurelösung zwischen 1,8 und 2 (Sambrook und Russell 2001).

Konzentration der doppelsträngigen DNA $[\mathrm{ng} / \mu \mathrm{l}]=\mathrm{OD}_{260} \times 50$

\subsection{Restriktionsverdau}

Für die Verifizierung der Identität eines Plasmids, beispielsweise nach der Aufreinigung von Plamid-DNA, wurde ein Restriktionsverdau durchgeführt. Die Restriktionsenzyme wurden so gewählt, dass die ringförmige Plamidstruktur an 
spezifischen, palindromischen Sequenzen geschnitten wurde. Anhand der Größe der Bande(n) in der anschließenden Gelelektrophorese (siehe 2.18) konnte das Plasmid identifiziert werden. Außerdem wurde für die Messung der Reparaturfähigkeit der Zelllinien ein einzelner definierter Doppelstrangbruch mit Hilfe von Restriktionsenzymen eingefügt.

Für die Suche nach einem Enzym, welches im Beginn des Luciferasegens schneidet und im restlichen Plasmid nicht, wurde das Wisconsin Sequence Analysis Package der Firma Genetics Computer Group (GCG, Madison, Wisconsin, USA) verwendet. Das Enzym Ehel von der Firma Fermentas (St. Leon-Rot) ist ein Neoschizomer zu Narl und produziert glatte Enden (blunt ends):

\section{5'-G G C^G C C-3'}

\section{3'-C C G^C G G-5'}

Der Verdau wurde nach Angaben des Herstellers durchgeführt, wobei das Volumen möglichst klein gehalten wurde. Zum Puffern wurde der mitgelieferte $\mathrm{Y}^{+} /$TTango $^{\mathrm{TM}_{-}}$ Puffer verwendet.

Nach der Hitzeinaktivierung bei $65^{\circ} \mathrm{C}$ für 20 min wurde eine Gelelektrophorese zur Kontrolle als auch zur Aufreinigung durchgeführt.

\subsection{Ligation von DNA}

DNA-Ligasen katalysieren die Ausbildung von Phosphodiesterbindungen zwischen einer freien 5'-Phosphatgruppe und einer 3'-Hydroxylgruppe von zwei miteinander kompatiblen DNA-Stücken. Für die Ligation wurde das Rapid DNA Ligation Kit der Firma Fermentas (St. Leon-Rot) verwendet. Im Gegensatz zu den Herstellerangaben wurde das Volumen möglichst klein gehalten. Eine Erfolgskontrolle erfolgte durch Hitzeschocktransformation.

\subsection{TBE-Agarose-Gelelektrophorese}

Um den Erfolg eines molekularbiologischen Arbeitsschrittes (zum Beispiel nach Restriktionsverdau) zu überprüfen, wurde eine TBE-Agarose-Gelelektrophorese durchgeführt. 
Es wurden 1\%ige (w/v) TBE-Agarose-Gele (SeaKem ${ }^{\circledR}$, Lonza, Basel, Schweiz) gegossen. Als Größenstandards wurden $3 \mu$ eines 1-kB-DNA-Leiter (New England Bio Labs, Frankfurt am Main) auf das Gel geladen und die Proben mit 6*loading solution dye (Fermentas, St. Leon-Rot) versetzt, damit sie schwerer wurden und nicht in den Puffer aufstiegen. Die Kontroll-Gele wurden bei 100-110 V, die präparativen Gele bei $80 \mathrm{~V}$ mit 1 x TBE-Puffer laufen gelassen und anschließend im Ethidiumbromidbad gefärbt. Die entstandenen Banden wurden schließlich unter UVLicht photographisch (FLUO_LINK TFL-20M, Biometra, Göttingen) festgehalten. Bei präparativen Gelen wurde anschließend die gewünschte Bande aus dem Gel ausgeschnitten und eluiert.

\section{TBE (TRIS-Borat-EDTA)-Puffer}

$10,8 \mathrm{~g}$ Tris(hydroxymethyl)-aminomethan (Merck, Darmstadt)

$5,5 \mathrm{~g} \quad$ Borsäure (Merck)

$4 \mathrm{ml} \quad 5 \mathrm{M}$ EDTA, pH 8,0 (Sigma-Aldrich, Steinheim)

ad $1000 \mathrm{ml}$ Aqua bidest., autoklaviert

\section{Ethidiumbromidbad}

$750 \mathrm{ml}$ Aqua bidest.

$50 \mu \mathrm{l} \quad$ Ethidiumbromid (Roth, Karlsruhe)

\subsection{Gewinnung von DNA-Fragmenten aus Agarosegelen}

Zur Gewinnung des geschnittenen Plasmids aus Agarosegelen wurde das "QIAquick Gel Extractions Kit" der Firma Qiagen (Hilden) verwendet. Das dabei eingesetzte "QIAquick Gel Extraction Kit Protocol" (Qiagen, 2002) arbeitet nach dem Prinzip der selektiven Bindung von DNA an eine Silikon-Gel-Membran. Durch die hohen Salzkonzentrationen bleibt die DNA an der Säulenmatrix haften, während Kontaminationen weggewaschen werden. Bei niedrigen Salzkonzentrationen kann die DNA eluiert werden. Die Gelelution wurde genau nach Protokoll durchgeführt und die mitgelieferten Puffer verwendet. 


\subsection{Statistische Auswertung}

Die statistische Auswertung erfolgte mit Hilfe des Statistikprogramms „SPSS für windows“, Version 11.5.

Zum Vergleich der Reparaturkapazitäten wurde der t-Test bei unabhängigen Stichproben verwendet. Eine Irrtumswahrscheinlichkeit von $p<0,05$ wurde als statistisch signifikant gewertet. 


\section{Ergebnisse}

\subsection{Zielsetzung der Arbeit}

DSB-Reparatur-Defizienz ist mit einem erhöhten Leukämierisiko assoziiert und gilt insbesondere als Prädiktor für de-novo- und sekundäre AML. Für eine individuelle Risikostratifizierung sollte deshalb ein Funktionsessay etabliert werden, welcher die Messung der DSB-Reparaturfähigkeit in primären Zellen bzw. Tumorzellen erlaubt. Dazu bietet sich der HCR-Test an. Qiao et al. zeigten die Überlegenheit des Luciferase-Systems gegenüber dem CAT-Verfahren (Qiao et al. 2002a). Dabei war der Luciferase-Test um den Faktor $10^{2}-10^{3}$ sensitiver und benötigte weniger Zellmengen. Dies sind entscheidende Voraussetzungen, um auch schwierig zu transfizierende Primärzellen zu untersuchen.

Das nicht-replikative pCMVIuc wurde freundlicherweise von M. Hedayati und L. Grossman von der Johns Hopkins Universität zu Verfügung gestellt. In dem pCMVluc-Plasmidkonstrukt wurde der originale SV40-Promoter des pGL3-Plasmids der Firma Promga (Mannheim) durch einen CMV-Promoter aus dem pRL-Plasmid (ebenfalls Promga, Mannheim) ersetzt (Qiao et al. 2002a). Durch die nichtreplikativen Eigenschaften ließen sich falsch-hohe Ergebnisse durch Replikation eines reparierten Plasmids ausschließen. Der CMV-Promotor induziert eine starke Expression des Luciferase-Gens und war deshalb für die Fragestellung dieser Arbeit besonders geeignet.

Um weitere unerwünschte Variablen, unter anderem Transfektionseffizienz, Zellproliferation und transfektionsassoziierten Zelltod, zu minimieren, wurde eine CoTransfektion mit dem Renilla-Luciferase exprimierenden pRL-CMV-Plasmid durchgeführt. Damit ließ sich die pCMVluc-Luciferase-Aktivität auf die RenillaLuciferase-Aktivität normalisieren. Als weitere Qualitätskontrolle wurde jedes Experiment mindestens 3-fach durchgeführt.

Der „DNA-Defekt“ wurde durch das Einbringen eines DNA-Doppelstrangbruchs mittels Restriktionsverdau im Luciferase-Gen gezielt herbeigeführt. Nur durch eine funktionierende, fehlerfreie DSB-Reaparatur ließ sich das Plasmid wieder so religieren, dass das pCMV-Luc-Gen korrekt abgelesen werden konnte und die Luciferase exprimiert wurde. Diese spaltete das im Überschuss zugegebene 
Luciferin, wobei die Lichtemission pro Zeit mit der gebildeten Luciferasemenge korrelierte.

Vorteile dieser Methode sind die direkte funktionelle Analyse und die Unabhängigkeit von indirekten genetischen Markern.

\subsection{Etablierung des Testsystems in primären Blutlymphozyten (PBL) und Zelllinien}

Um die Einsetzbarkeit des Tests bei primären Zellen zu untersuchen, wurde als erstes die HCR in primären Blutlymphozyten gesunder Spender analysiert. Direkt nach der Blutentnahme wurden die mononukleären Zellen mittels Ficoll-Gradient gewonnen und eingefroren, wobei dabei die sofortige Verarbeitung ( $<3 \mathrm{~h})$ der Blutprobe wichtig war. Ein Lagern der Blutprobe bei $4{ }^{\circ} \mathrm{C}$ über $24 \mathrm{~h}$ vor Isolierung mit Ficoll-Gradient ergab Luciferase-Expressionswerte im Bereich der „Leertransfektion“. Die mittlere Luciferase-Expression betrug 107 RLU (48 h-Kultur) bzw. 104 RLU (72 h-Kultur). Diese Werte waren nicht signifikant ( $p=0,753$ bzw. $p=0,903)$ gegenüber dem Hintergrundwert.

Tabelle 5: PBL-Kulturen von Blutproben, welche vor Isolierung $24 \mathrm{~h}$ bei $4{ }^{\circ} \mathrm{C}$ gelagert wurden.

\begin{tabular}{|l|r|r|r|}
\hline Ansatz & \multicolumn{3}{|c|}{ RLU } \\
\hline & Transfektion 1 & Transfektion 2 & Transfektion 3 \\
\hline PBL (ohne Plasmid) & 112 & 104 & 99 \\
\hline PBL+ pCMVluc, 48 h-Kultur & 104 & 116 & 101 \\
\hline PBL+ pCMVluc, 72 h-Kultur & 110 & 98 & 105 \\
\hline
\end{tabular}




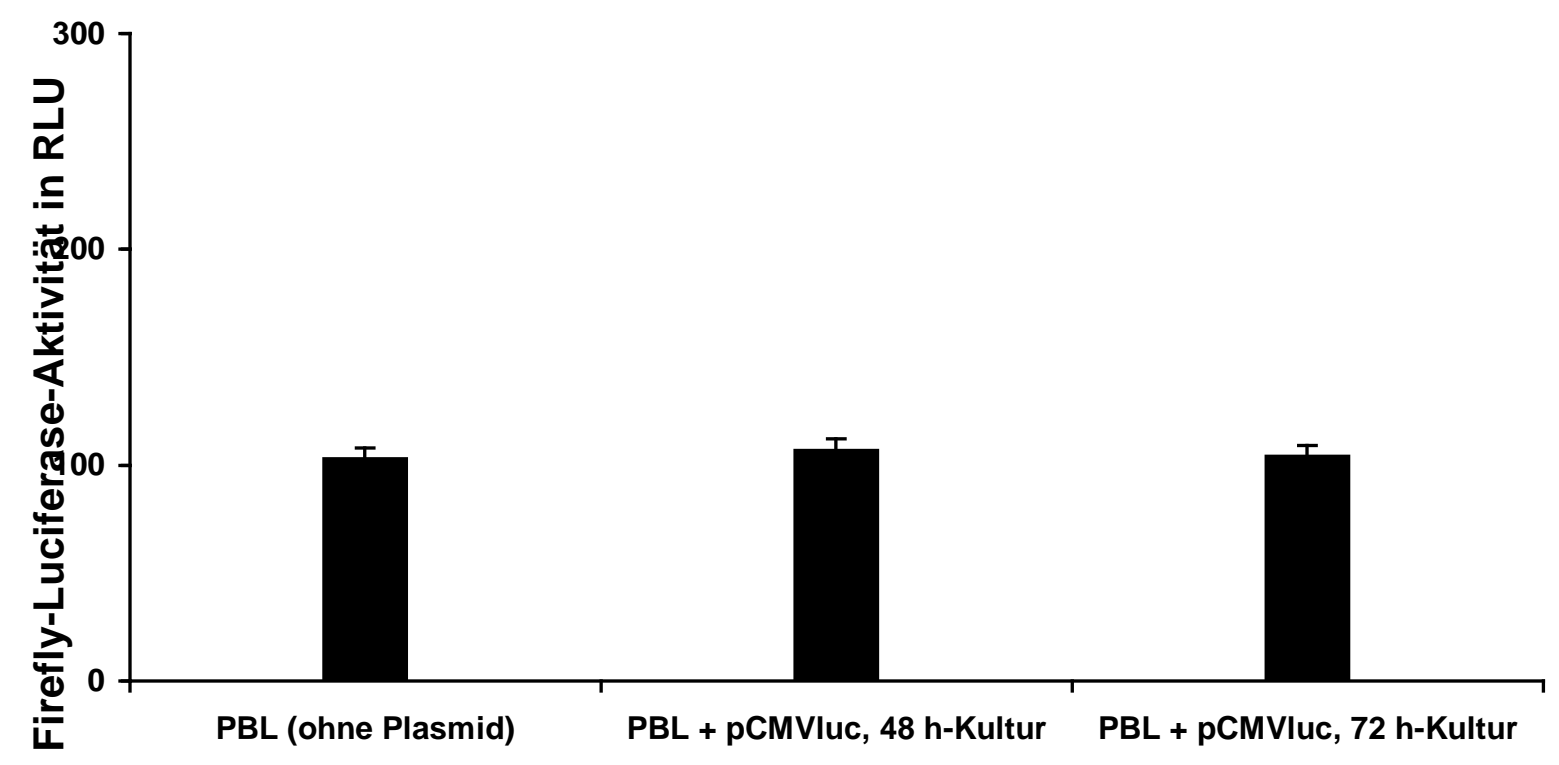

Abbildung 7: Firelfly-Luciferase-Aktivität bei Transfektion in Blutproben, welche vor Isolierung $24 \mathrm{~h}$ bei $4^{\circ} \mathrm{C}$ gelagert wurden. In der Grafik sind die Ergebnisse aus mindestens 3 unabhängigen Versuchen mit Standardabweichung dargestellt. Sie zeigen, dass sich die Werte der LuciferaseExpression bei Lagerung der Blutproben von $24 \mathrm{~h}$ vor Isolation nicht signifikant von den Leertransfektionswerten ohne Plasmid unterscheiden.

Nach dem Wiederauftauen der sofort verarbeiteten Proben wurde natives pCMVluc in PBL-Kulturen transfiziert. Mit diesem Procedere ließ sich die Verlässlichkeit und Einsetzbarkeit des Systems nachweisen. Mit einer transfizierten Zellmenge von $2 \mathrm{x}$ $10^{5}$ Zellen betrug der Mittelwert der "Leertransfektion“ ohne Plasmid 105 RLU. Der Mittelwert der 72 h-Kultur lag bei 205801 RLU. Somit konnte eine signifikante Expression erzielt werden, die etwa 2000-fach über dem Hintergrund lag $(p<0,001)$. Ein großer Unterschied war die Kultivierungszeit, wobei die Kulturen nach $72 \mathrm{~h}$ sehr viel stärkere Luciferase-Expressionen zeigten als nach $48 \mathrm{~h}$. Jedoch wiesen auch die 48 h-Kulturen mit einer mittlere Luciferase-Expression von 15823 RLU im Vergleich zur "Leertransfektion“ signifikante Werte auf $(p<0,001)$. 
Tabelle 6: PBL-Kulturen von frisch verarbeiteten Blutproben

\begin{tabular}{|l|r|r|r|}
\hline Ansatz & \multicolumn{3}{|c|}{ RLU } \\
\hline & Transfektion 1 & Transfektion 2 & Transfektion 3 \\
\hline PBL ohne Plasmid & 112 & 104 & 99 \\
\hline PBL+ pCMVluc, 48 h Kultur & 15631 & 16857 & 14982 \\
\hline PBL+ pCMVluc, 72 h Kultur & 203462 & 213798 & 200145 \\
\hline
\end{tabular}

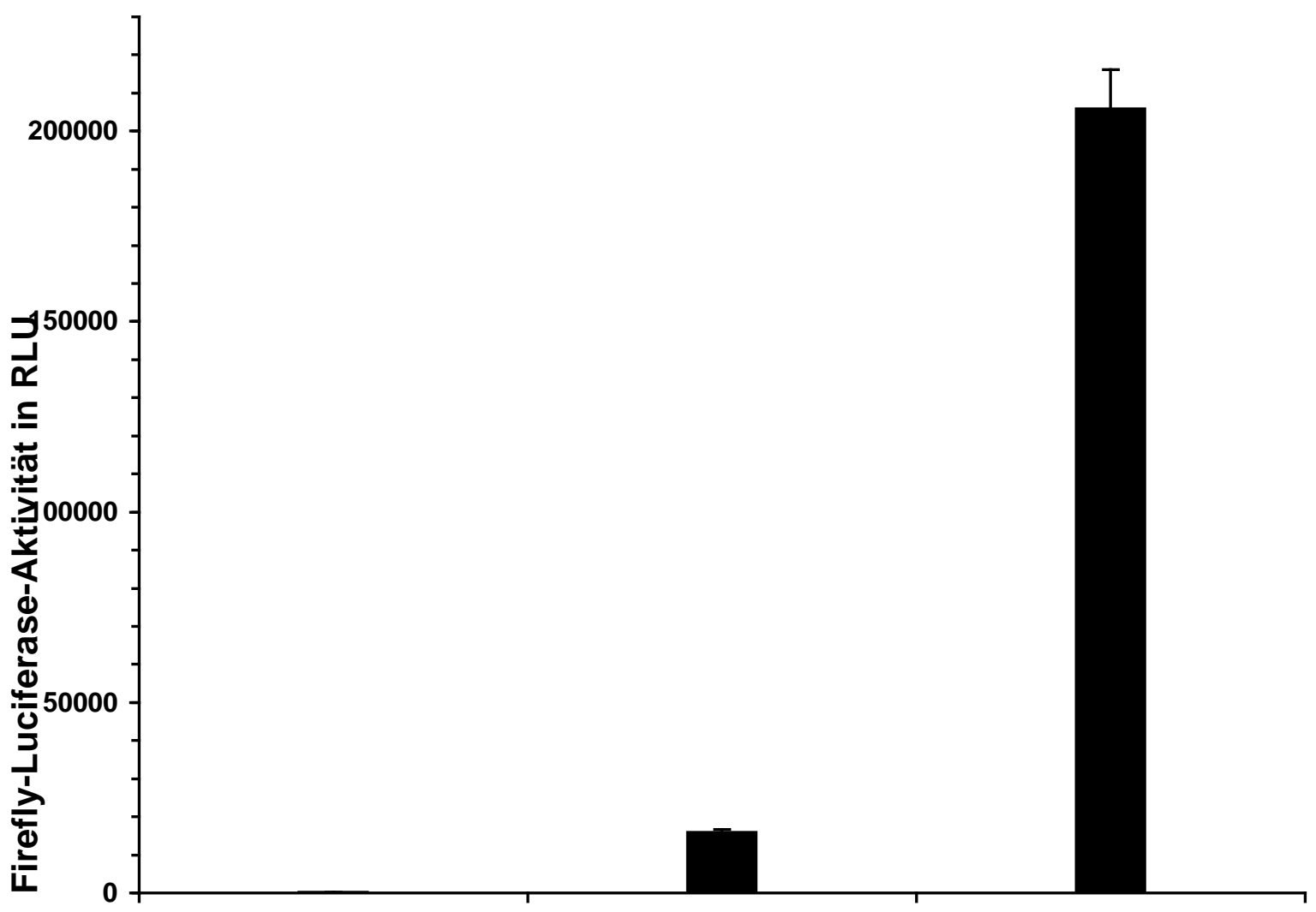

PBL (ohne Plasmid)

PBL + pCMVluc, 48 h-Kultur PBL + pCMVluc, 72 h-Kultur

Abbildung 8: Firelfly-Luciferase-Aktivität bei Transfektion mit PBL Kulturen von frisch verarbeiteten Blutproben. In der Grafik sind die Ergebnisse aus mindestens 3 unabhängigen Versuchen mit Standardabweichung dargestellt. Sie zeigen, dass sich die Werte der LuciferaseExpression bei bei PBL-Kulturen von frisch verarbeiteten Blutproben signifikant $(p<0,001)$ von den Leertransfektionswerten ohne Plasmid unterscheiden.

\subsection{Optimierung der Transfektionsbedingungen für Leukämiezelllinien}

Des Weiteren wurden in mehreren Versuchen die optimalen Zell- und Plasmidmengen für die einzelnen Zelllinien individuell bestimmt. Wie in Tabelle 7 
beispielhaft an der Zelllinie CCRF-CEM gezeigt, wurden ausgehend von $1 \times 10^{6}$ Zellen und 75ng Plasmid verschiedene Plasmidkonzentrationen und Zellmengen getestet. Für jede Zelllinie wurde die optimale pCMVluc-Menge pro Versuch ermittelt. Dabei sollten mit möglichst geringen Zellzahlen die Expression für das Plasmid pCMVluc optimalerweise zwischen 100000 und 200000 RLU und für pRL-CMV möglichst hoch sein. Somit ist der optimale Versuchsansatz für die Zelllinie CCRFCEM mit $1 \times 10^{6}$ Zellen und je 75 ng Plasmid.

In gleicher Weise wurden auch für die übrigen Zelllinien GM03715, AG10107, Kasumi-1, K562 und SU-DHL-4 die optimalen Transfektionsbedingungen ermittelt, welche in Tabelle 8 dargestellt sind.

Tabelle 7: Optimierung der Transfektionsansätze am Beispiel der Zelllinie CCRF-CEM als Messung der RLU bei Variation von Zellzahl und Plasmidmenge. Ziel ist eine LuciferaseExpression für das Plasmid pCMVluc im Bereich von 100000 bis 200000 RLU bei möglichst geringer Zellzahl. Dies wurde in mindestens 3 unabhängigen Versuchen ermittelt.

\begin{tabular}{|c|c|c|c|c|c|}
\hline 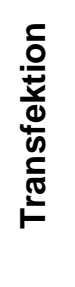 & 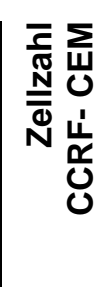 & 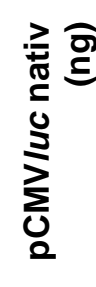 & 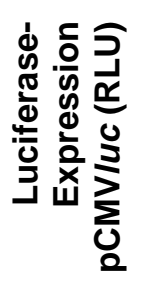 & 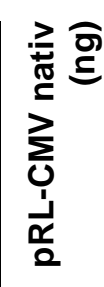 & 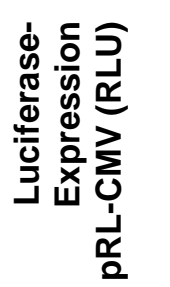 \\
\hline 1 & $1 \times 10^{6}$ & 75 & 194903 & 75 & 5109 \\
\hline 2 & $1 \times 10^{6}$ & 75 & 144252 & 75 & 3458 \\
\hline 3 & $1 \times 10^{6}$ & 75 & 181617 & 75 & 4231 \\
\hline 4 & $1 \times 10^{6}$ & 150 & 156664 & 150 & 2688 \\
\hline 5 & $1 \times 10^{6}$ & 150 & 176289 & 150 & 3059 \\
\hline 6 & $1 \times 10^{6}$ & 150 & 117975 & 150 & 2505 \\
\hline 7 & $1 \times 10^{6}$ & 300 & 38278 & 300 & 1696 \\
\hline 8 & $1 \times 10^{6}$ & 300 & 59607 & 300 & 1928 \\
\hline 9 & $1 \times 10^{6}$ & 300 & 51173 & 300 & 2032 \\
\hline 10 & $3 \times 10^{6}$ & 150 & 257741 & 150 & 2524 \\
\hline 11 & $3 \times 10^{6}$ & 150 & 220228 & 150 & 2774 \\
\hline 12 & $3 \times 10^{6}$ & 150 & 238001 & 150 & 2617 \\
\hline
\end{tabular}


Tabelle 8: optimale Tranfektionsansätze: Für jede Zelllinie wurde in mindestens 3 unabhängigen Versuchen die optimale Zellzahl sowie die optimale Plasmidmenge mit Hilfe von Titrationstransfektionenen bestimmt.

\begin{tabular}{|l|r|r|r|}
\hline Zelllinie & \multicolumn{1}{|l|}{$\begin{array}{l}\text { Zellzahl } \\
\text { pro Ansatz }\end{array}$} & $\begin{array}{l}\text { Menge pCMVLuc (nativ oder } \\
\text { geschnitten) pro Ansatz }\end{array}$ & $\begin{array}{l}\text { Menge pRL-CMV pro } \\
\text { Ansatz }\end{array}$ \\
\hline GM 03715 & $1,5 \times 10^{6}$ & $250 \mathrm{ng}$ & $75 \mathrm{ng}$ \\
\hline AG 10107 & $2 \times 10^{6}$ & $50 \mathrm{ng}$ & $250 \mathrm{ng}$ \\
\hline K 562 & $1 \times 10^{6}$ & $75 \mathrm{ng}$ & $100 \mathrm{ng}$ \\
\hline Kasumi & $3 \times 10^{6}$ & $250 \mathrm{ng}$ & $250 \mathrm{ng}$ \\
\hline SU-DHL-4 & $3 \times 10^{6}$ & $75 \mathrm{ng}$ & $75 \mathrm{ng}$ \\
\hline CCRF-CEM & $1 \times 10^{6}$ & &
\end{tabular}

\subsection{Wahl des Restriktionsenzyms}

Der Verdau des pCMVIuc durch ein Restriktionsenzym wurde so gewählt, dass zwei wichtige Kriterien erfüllt wurden. Zum einen durfte es nur eine Schnittstelle im Genom des Plasmids geben. Zum anderen sollte dieser Schnitt in der vorderen Region des Firefly-Luciferase-Gens liegen. Ein Schnitt zwischen Promotor und Gen hätte mit erhöhter Wahrscheinlichkeit auch bei fehlerhafter Reparatur zu einer korrekten Expression und damit zu falsch-positiven Ergebnissen geführt. Diese Suche wurde mit dem Analyseprogramm „Wisconsin Sequence Analysis Package“ der Firma Genetics Computer Group ausgeführt.

ATG GAA GAC GCC AAA AAC ATA AAG AAA GGC CCG GC $\&$ G CCA TTC TAT CCT CTA GAG GAT GGA ACC 1

Abbildung 9: Sequenzausschnitt des Luciferasegens von Base 1 bis 63. Die Erkennungssequenz des Enzyms Ehe I entspricht dem markierten Bereich und führt zu einem Schnitt nach Base 35 (\&<). Dies ist die einzige Schnittstelle des Enzyms im Plasmid. 
Das Enzym Ehel schneidet im Beginn des Luciferase-Gens nach Base 35, sodass eine korrekte Reparatur für die Funktion der Luciferase entscheidend ist. Der Verdau des Plasmids wurde mittels Gelelektrophorese kontrolliert.

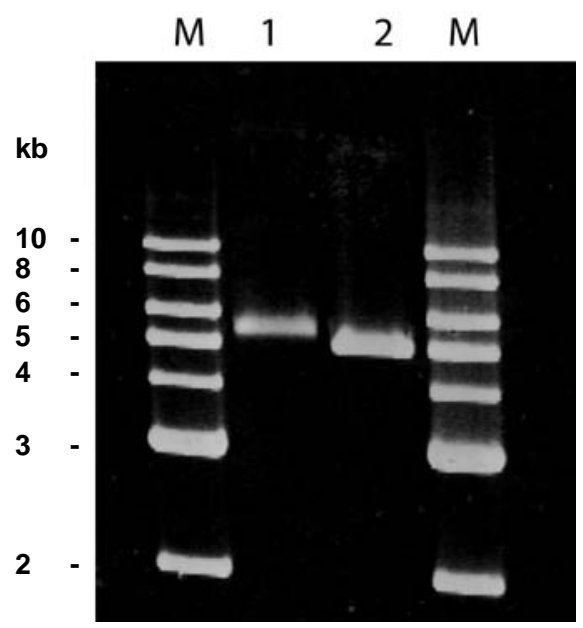

Abbildung 10: Gelelektrophorese zur Kontrolle des Restriktionsverdaus mit Ehe I: Marker (M), pCMVluc mit Ehe I geschnitten (1), pCMVluc nativ (2)

\subsection{Gelelution und Aufreinigung}

Obwohl in der Gelelektrophorese keine zweite Bande zu erkennen war und es damit keinen Hinweis auf das Vorhandensein ungeschnittener Plasmidreste gab, zeigte sich bei Vorversuchen ohne Aufreinigung (via Gelelution) eine signifikant erhöhte Lichtemission sowohl in den Wildtypzelllinien als auch in den Leukämiezelllinien verglichen zu Transfektionen mit durch Gelelution aufgereinigtem Plasmid $(p<0,001)$. Dieses Ergebnis ist in Tabelle 9 und Abbildung 11 beispielhaft für die Zellinie GM03715 dargestellt. Um mögliche Verunreinigung durch ungeschnittenes Plasmid zu vermeiden, wurde der Ansatz nach dem Restriktionsverdau für alle weiteren Versuche durch Gelelektrophorese und anschließende Elution aufgereinigt. 
Tabelle 9: Messwerte für GM03715 in Abhängigkeit der Aufreinigung durch Gelelution: es zeigte sich eine signifikant erhöhte Lichtemission, wenn das linearisierte pCMVluc ohne Aufreinigung mittels Gelelution eingesetzt wurde

\begin{tabular}{|c|c|c|c|c|c|c|c|c|c|c|}
\hline 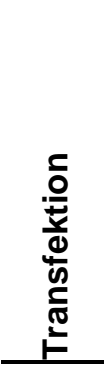 & 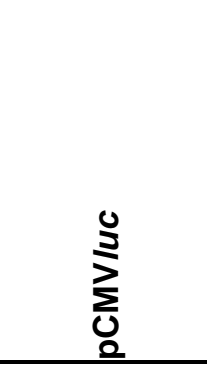 & 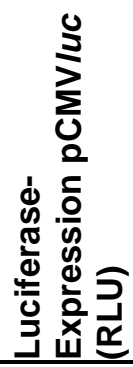 & 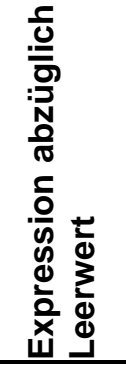 & 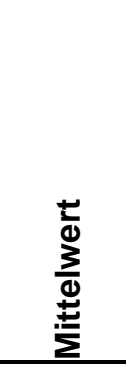 & 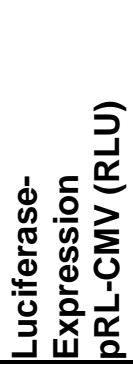 & 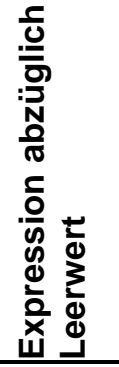 & 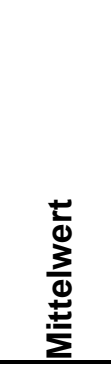 & 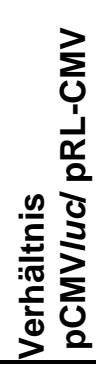 & 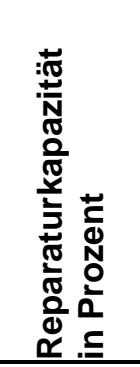 & 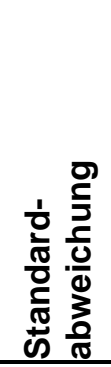 \\
\hline 1 & nativ & 279626 & 279122 & & 36427 & 35313 & & 7,90 & & \\
\hline 2 & & 243216 & 242712 & 271479 & 23689 & 22575 & 29482 & 10,75 & & \\
\hline 3 & & 293108 & 292604 & & 31671 & 30557 & & 9,58 & & \\
\hline 4 & +Ehel & 90984 & 90480 & & 23884 & 22770 & & 3,97 & $43,15 \%$ & \\
\hline 5 & ohne & 84204 & 83700 & 83308 & 28950 & 27836 & 24389 & 3,01 & $32,65 \%$ & $5,31 \%$ \\
\hline 6 & Aufreinigung & 76248 & 75744 & & 23677 & 22563 & & 3,36 & $36,46 \%$ & \\
\hline 7 & +Ehel & 50296 & 49792 & & 20457 & 19343 & & 2,57 & $27,35 \%$ & \\
\hline 8 & mit & 54040 & 53536 & 50763 & 21087 & 19973 & 19721 & 2,68 & $28,48 \%$ & $1,13 \%$ \\
\hline 9 & Aufreinigung & 49465 & 48961 & & 20960 & 19846 & & 2,47 & $26,22 \%$ & \\
\hline leer 1 & & 574 & & & 1211 & & & & & \\
\hline leer 2 & & 519 & & & 1147 & & & & & \\
\hline leer 3 & & 419 & & & 984 & & & & & \\
\hline
\end{tabular}

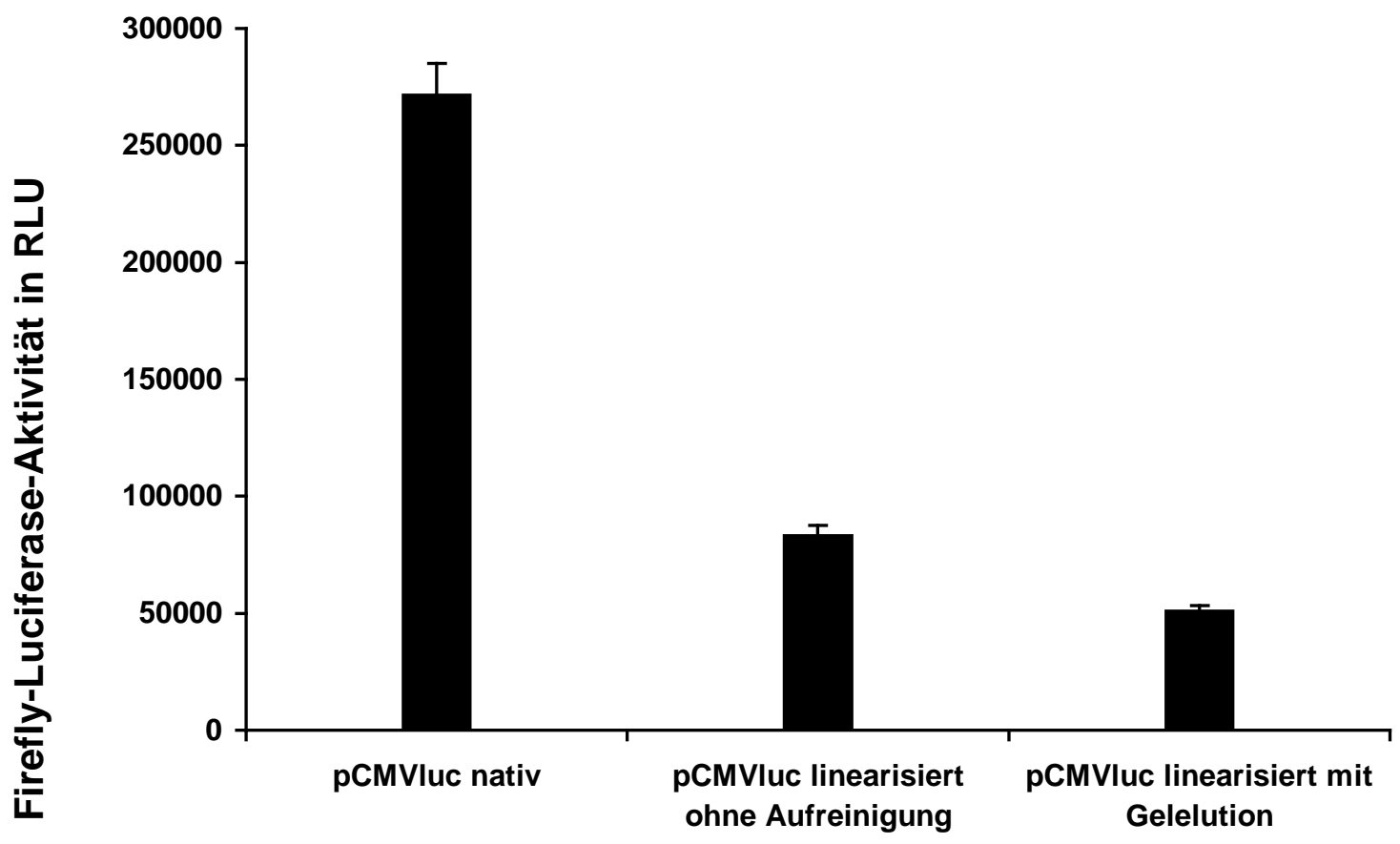

Abbildung 11: Lichtemission nach Durchführung des Wirtszell-Reaktivierungs-Test mit der Zelllinie GM03715: In der Grafik sind die Ergebnisse aus mindestens 3 unabhängigen Versuchen mit Standardabweichung dargestellt Die Lichtemission in den Versuchen mit linearisiertem pCMVluc ohne weitere Aufreinigung zeigte signifikant höhere Werte als das linearisierte Plasmid mit Aufreinigung via Gelelution. RLU (,relative light units“) relative Lichteinheiten 


\subsection{In-vitro-Religation}

Mittels der oben beschriebenen Versuchsvorbereitungen zeigte sich ein funktionierendes Testsystem. Nach Ansetzen größerer Plasmidmengen für die Versuche konnten allerdings anders als in den Vorversuchen mit dem geschnittenen, geleluierten Plasmid auch bei den Wildtypzelllinien kaum noch Lichtemissionen erzielt werden.

Um die generelle Religationsfähigkeit des Plasmids zu überprüfen, wurde in mehreren Ansätzen versucht, sowohl das geschnittene, als auch das geschnittene, geleluierte Plasmid mittels T4-Ligase in vitro zu religieren. Der Erfolg der Religation wurde durch Transformation in kompetente Bakterien nachgewiesen. Nur Bakterien mit religiertem Plasmid konnten das Ampicillin-Resistenz-Gen des Plasmids zum Wachstum auf ampicillinhaltigen Agarplatten nutzen. Die Menge der Bakterienkolonien gab bei gleicher Menge eingesetztem Plasmids Rückschlüsse auf die Religationsfähigkeit in vitro (siehe Tabelle 10).

Als Kontrollen wurden natives pCMVluc, geschnittenes pCMVluc und geschnittenes, geleluiertes pCMVluc ebenfalls transformiert.

Dabei zeigten Ansätze mit nativem pCMVluc nach 24-stündiger Inkubation eine Koloniezahl von 500 Kolonien pro Agarplatte, und auch mit geschnittenem, religiertem pCMVluc (ohne Aufreinigung) ließ sich ein guter Bewuchs mit 300 Kolonien pro Agarplatte darstellen. Einige wenige Kolonien wuchsen auf den Platten mit dem geschnittenen pCMVluc, allerdings ließ sich kein Bewuchs der Platten mit dem geschnittenen, geleluierten pCMVluc respektive dem geschnittenen, geleluierten, religierten pCMVluc nachweisen. 
Tabelle 10: Transformationsergebnisse nach 24 h, in-vitro-Religation mit QIAquick Gel Extraction Kit: Darstellung repräsentativer Einzelergebnisse

\begin{tabular}{|l|l|}
\hline Transformationsansatz & Koloniezahl pro Agarplatte \\
\hline pCMVluc nativ & 500 \\
\hline pCMVluc geschnitten, keine Gelelution & 8 \\
\hline pCMVluc geschnitten, mit Gelelution & 0 \\
\hline pCMVluc geschnitten, ohne Gelelution, religiert & 300 \\
\hline pCMVluc geschnitten mit Gelelution, religiert & 0 \\
\hline
\end{tabular}

Auch die Variation der Plasmidmenge, der Ligationszeit durch die T4-Ligase (5 min vs. $15 \mathrm{~min}$ ) und des Gelelutionskits (der Firma QIAGEN, Hilden versus GELase ${ }^{\mathrm{TM}}$ der Firma Biozym, Hess. Oldendorf) zeigte kaum Wachstum in den Versuchsansätzen mit geschnittenem, geleluiertem und religiertem Plasmid (siehe Tabelle 11).

Tabelle 11: Transformationsergebnisse nach 24 h, Variation des Gelelutionskits: Darstellung repräsentativer Einzelergebnisse

\begin{tabular}{|l|l|}
\hline Transformationsansatz & Koloniezahl pro Agarplatte \\
\hline pCMVluc nativ & 500 \\
\hline $\begin{array}{l}\text { pCMVluc geschnitten, mit Gelelution, religiert } \\
\text { (QIAquick), Ligationszeit } 5 \text { min }\end{array}$ & 1 \\
\hline $\begin{array}{l}\text { pCMVluc geschnitten, mit Gelelution, religiert } \\
\text { (QIAquick), Ligationszeit } 15 \text { min }\end{array}$ & 3 \\
\hline $\begin{array}{l}\text { pCMVluc geschnitten mit Gelelution, religiert } \\
\text { (GELase }\end{array}$ & 2 \\
\hline
\end{tabular}

Da das Problem zwischen Verdau und Gelelution liegen musste, wurde als letztmögliche Fehlerquelle der Transilluminator gewechselt, da die Schädigung der DNA bei $366 \mathrm{~nm}$ deutlich geringer ist als bei $254 \mathrm{~nm}$ (Brunk und Simpson 1977). Diese Veränderung zeigte einen guten Bewuchs der transformierten Bakterienzellen (siehe Tabelle 12). 
Tabelle 12: Transformationsergebnisse nach $24 \mathrm{~h}$, Gelelution durch QIAquick Gel Extraction Kit: Darstellung repräsentativer Einzelergebnisse

\begin{tabular}{|l|l|}
\hline Transformationsansatz & Koloniezahl pro Agarplatte \\
\hline pCMVluc nativ & 500 \\
\hline $\begin{array}{l}\text { pCMVluc geschnitten mit Gelelution, UV-Tisch von } \\
254 \mathrm{~nm}, \text { religiert }\end{array}$ & 2 \\
\hline $\begin{array}{l}\text { pCMVluc geschnitten mit Gelelution, UV-Tisch von } \\
366 \mathrm{~nm}, \text { religiert }\end{array}$ & 350 \\
\hline
\end{tabular}

Retrospektiv lag der Grund für die positiven Ergebnisse in den Vorversuchen in der Tatsache, dass das genutzte Plasmid keinen UV-Strahlenkontakt hatte. Für die Elution wurde das Gel in den Vorversuchen nach Standard laufen gelassen, vor dem Färben im Ethidiumbromidbad allerdings zerschnitten und nur die 1kB-Marker und eine Bahn des Plasmids gefärbt. Der Rest wurde nach Markierung der Bande ohne Ethidiumbromid- oder UV-Kontakt ausgeschnitten. Leider ließ sich bei der anschließenden Aufreinigung nicht die gewünschte Konzentration erzielen, sodass für die Hauptversuche von dieser Methode Abstand genommen wurde.

In umfangreichen Optimierungsschritten konnte eine wichtige Fehlerquelle (der stark schädigende Einfluss des $254 \mathrm{~nm}$ Transilluminators auf die Plasmid-DNA im Rahmen der Gelelution) ausgemacht werden. Die Verwendung eines Transilluminators von $366 \mathrm{~nm}$ konnte dieses Problem beheben, so dass das in den folgenden Versuchen verwendete Plasmid auf dem langwelligeren UV-Tisch mit Lichtemission bei $366 \mathrm{~nm}$ präpariert wurde.

\subsection{DSB-Reparatur in menschlichen primären Tumorzellen}

\subsubsection{Wildtypzelllinien}

\subsubsection{GM03715}

Die Zelllinie GM03715 ist eine mit dem Epstein-Barr-Virus transformierte, immortalisierte Wildtypzelllinie. Die mittlere Luciferase-Expression mit nativem 
Plasmid lag bei 271479 RLU. Die Ergebnisse der Transfektionen sind in Tabelle 13 dargestellt. Die Expression des Plasmids pCMVluc wurde auf die Expression des Kontrollplasmids pRL-CMV normalisiert und die Reparaturkapazität als Ratio aus normalisierter Expression des geschnittenen pCMVluc und normalisierter Expression des nativen pCMVluc errechnet. Für die Wildtypzelllinie GM03715 ergab sich so eine mittlere Reparaturkapazität von 27,35 \% bei einer Standardabweichung von 1,13 \%.

Tabelle 13: Messwerte für GM03715

\begin{tabular}{|c|c|c|c|c|c|c|c|c|c|c|}
\hline 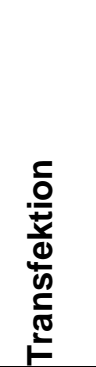 & 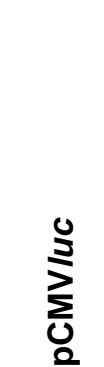 & 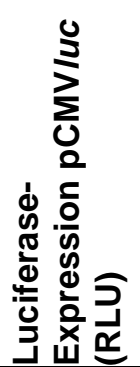 & 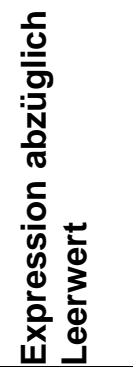 & $\begin{array}{l}\frac{ \pm}{0} \\
\frac{3}{0} \\
\frac{ \pm}{ \pm} \\
\Sigma\end{array}$ & 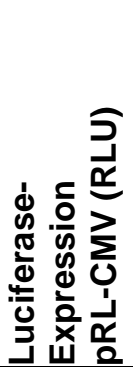 & 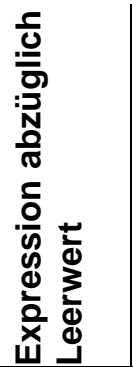 & 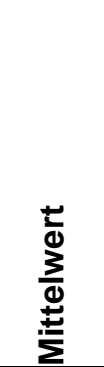 & 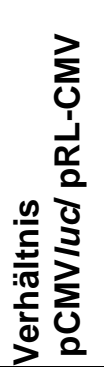 & 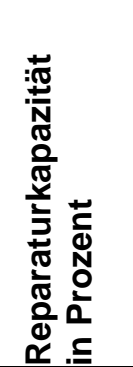 & 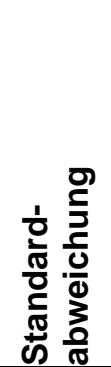 \\
\hline 1 & nativ & 279626 & 279122 & & 36427 & 35313 & & 7,90 & & \\
\hline 2 & nativ & 243216 & 242712 & 271479 & 23689 & 22575 & 29482 & 10,75 & & \\
\hline 3 & nativ & 293108 & 292604 & & 31671 & 30557 & & 9,58 & & \\
\hline 4 & +Ehel & 50296 & 49792 & & 20457 & 19343 & & 2,57 & $27,35 \%$ & \\
\hline 5 & +Ehel & 54040 & 53536 & 50763 & 21087 & 19973 & 19721 & 2,68 & $28,48 \%$ & $1,13 \%$ \\
\hline 6 & +Ehel & 49465 & 48961 & & 20960 & 19846 & & 2,47 & $26,22 \%$ & \\
\hline leer 1 & & 574 & & & 1211 & & & & & \\
\hline leer 2 & & 519 & & & 1147 & & & & & \\
\hline leer 3 & & 419 & & & 984 & & & & & \\
\hline
\end{tabular}

\subsubsection{AG10107}

Die Zellinie AG10107 ist ebenfalls eine immortalisierte Wildtypzelllinie. Die mittlere Luciferase-Expression mit nativem Plasmid lag bei 571835 RLU. Die mittlere Reparaturkapazität betrug 10,79 \% und wies eine Standardabweichung von 0,71\% auf. 
Tabelle 14: Messwerte für AG10107

\begin{tabular}{|c|c|c|c|c|c|c|c|c|c|c|}
\hline 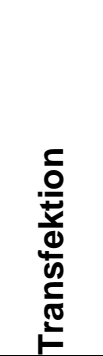 & 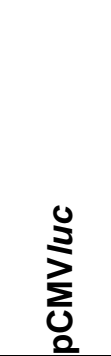 & 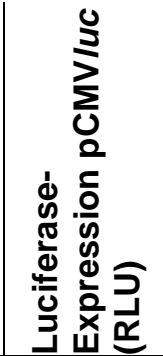 & 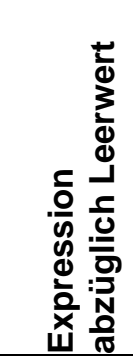 & 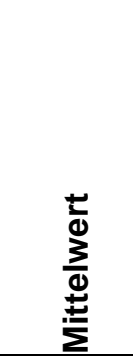 & 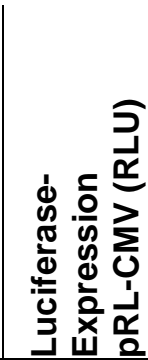 & 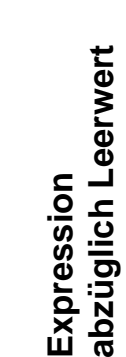 & 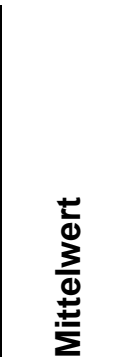 & 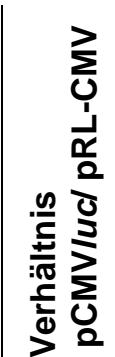 & 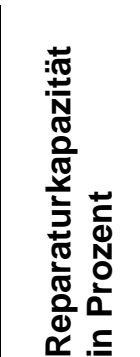 & 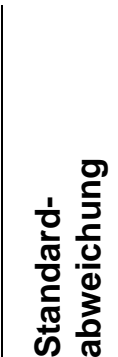 \\
\hline 1 & nativ & 690666 & 690376 & & 50589 & 49183 & & 14,04 & & \\
\hline 2 & nativ & 481509 & 481219 & 571835 & 80469 & 79063 & 61780 & 6,09 & & \\
\hline 3 & nativ & 544201 & 543911 & & 58501 & 57095 & & 9,53 & & \\
\hline 4 & + Ëhel & 32295 & 32005 & & 29350 & 27944 & & 1,15 & $11,59 \%$ & \\
\hline 5 & +Ehel & 35954 & 35664 & 31360 & 36643 & 35237 & 29513 & 1,01 & $10,24 \%$ & $0,71 \%$ \\
\hline 6 & +Ehel & 26701 & 26411 & & 26765 & 25359 & & 1,04 & $10,54 \%$ & \\
\hline $\begin{array}{l}\text { leer } 1 \\
\text { leer } 2 \\
\text { leer } 3\end{array}$ & & $\begin{array}{l}372 \\
251 \\
248\end{array}$ & & & $\begin{array}{l}1368 \\
1422 \\
1429\end{array}$ & & & & & \\
\hline
\end{tabular}

\subsubsection{Tumorzelllinien}

\subsubsection{Kasumi-1}

Die Zelllinie Kasumi-1 ist eine aus dem peripheren Blut etablierte MyeloblastenZelllinie eines 7-jährigen japanischen Jungen mit AML mit einer Translokation t(8;21). Die Luciferase-Expression bei Transfektion mit nativem pCMVluc ergab einen Mittelwert von 62128 RLU. Die mittlere Reparaturkapazität betrug 6,44 \% und war damit signifikant gegenüber den Wildtypzelllinien GM03715 und AG10107 erniedrigt $(p=0,002$ bzw. $p<0,001)$. Die Standardabweichung lag bei 0,75 \%. 
Tabelle 15: Messwerte für Kasumi-1

\begin{tabular}{|c|c|c|c|c|c|c|c|c|c|c|}
\hline 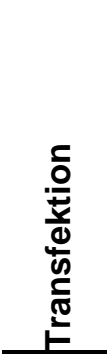 & 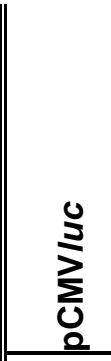 & 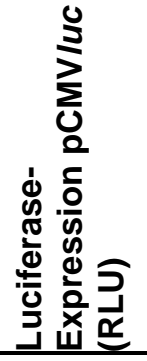 & 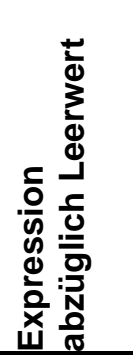 & 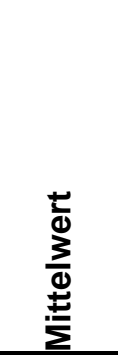 & 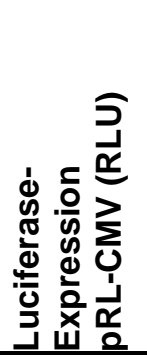 & 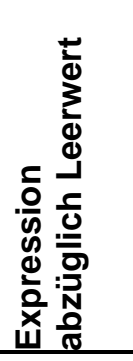 & 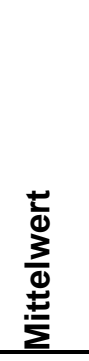 & 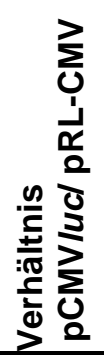 & 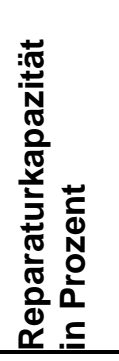 & 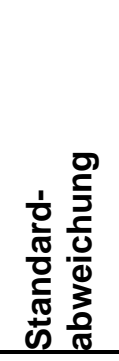 \\
\hline 1 & nativ & 73028 & 72555 & & 2933 & 1981 & & 36,62 & & \\
\hline 2 & nativ & 60752 & 60279 & 62128 & 2345 & 1393 & 1527 & 43,26 & & \\
\hline 3 & nativ & 54023 & 53550 & & 2157 & 1205 & & 44,43 & & \\
\hline 4 & +Ehel & 4955 & 4482 & & 2486 & 1534 & & 2,92 & $7,05 \%$ & \\
\hline 5 & +Ehel & 3999 & 3526 & 3760 & 2471 & 1519 & 1412 & 2,32 & $5,60 \%$ & $0,75 \%$ \\
\hline 6 & +Ehel & 3744 & 3271 & & 2134 & 1182 & & 2,77 & $6,68 \%$ & \\
\hline leer 1 & & 427 & & & 1251 & & & & & \\
\hline leer 2 & & 688 & & & 1154 & & & & & \\
\hline leer 3 & & 304 & & & 450 & & & & & \\
\hline
\end{tabular}

\subsubsection{K562}

Die Zelllinie K562 wurde aus einem Pleuraerguss eines 53-jährigen CML-Patienten mit Blastenkrise gewonnen. Der Mittelwert der Luciferase-Expression bei Transfektion mit nativem Plasmid war 376147 RLU. Die mittlere Reparaturkapazität betrug 26,66 \% und lag damit bei einer Standardabweichung von 1,25 \% im Bereich der Reparaturfähigkeit der Zelllinie GM03715.

Tabelle 16: Messwerte für K562

\begin{tabular}{|c|c|c|c|c|c|c|c|c|c|c|}
\hline 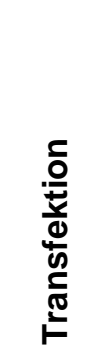 & 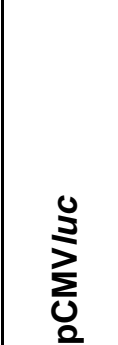 & 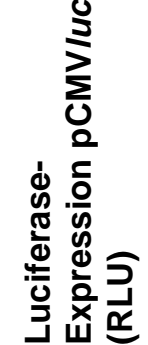 & & 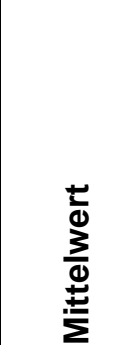 & 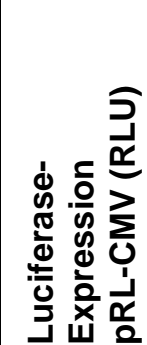 & 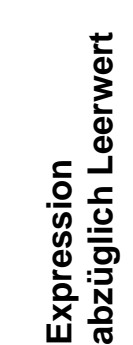 & 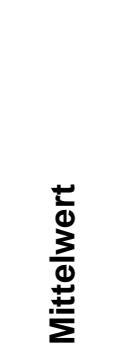 & 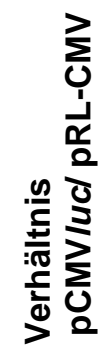 & 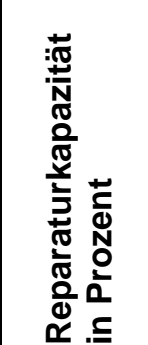 & 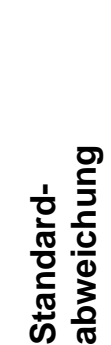 \\
\hline 1 & nativ & 290019 & 289532 & & 30672 & 28299 & & 10,23 & & \\
\hline 2 & nativ & 418893 & 418406 & 376147 & 38604 & 36231 & 33920 & 11,55 & & \\
\hline 3 & nativ & 420990 & 420503 & & 39605 & 37232 & & 11,29 & & \\
\hline 4 & + Ehel & 89549 & 89062 & & 33120 & 30747 & & 2,90 & $26,27 \%$ & \\
\hline 5 & +Ehel & 91717 & 91230 & 96096 & 34644 & 32271 & 32644 & 2,83 & $25,64 \%$ & $1,25 \%$ \\
\hline 6 & +Ehel & 108482 & 107995 & & 37288 & 34915 & & 3,09 & $28,06 \%$ & \\
\hline leer 1 & & 505 & & & 2484 & & & & & \\
\hline leer 2 & & 469 & & & 2268 & & & & & \\
\hline leer 3 & & 415 & & & 2368 & & & & & \\
\hline
\end{tabular}




\subsubsection{SU-DHL-4}

Die Zelllinie SU-DHL-4 stammt aus Aszites eines 38-jährigen Patienten mit B-ZellNon-Hodgkin-Lymphom. Die mittlere Luciferase-Expression mit nativem Plasmid ergab 62128 RLU. Die mittlere Reparaturkapazität betrug 4,44\% und war statistisch signifikant gegenüber GM03715 und AG10107 erniedrigt ( $p=0,001$ bzw. $p<0,001)$. Die Standardabweichung lag bei 0,33\%.

Tabelle 17: Messwerte für SU-DHL-4

\begin{tabular}{|c|c|c|c|c|c|c|c|c|c|c|}
\hline 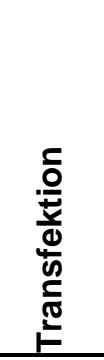 & $\sum_{\substack{0 \\
\Sigma}}^{0}$ & 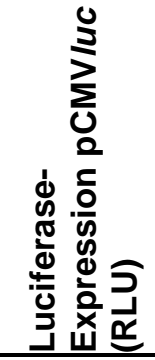 & 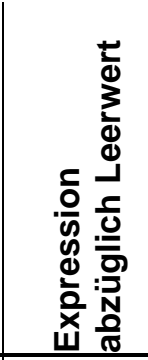 & 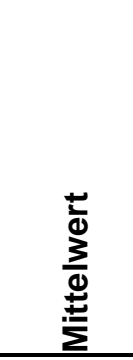 & 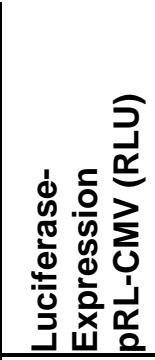 & 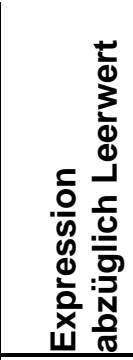 & 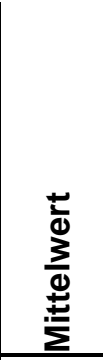 & 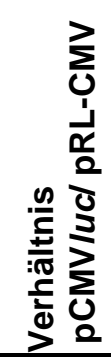 & 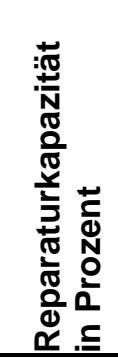 & 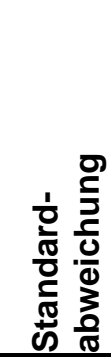 \\
\hline 1 & nativ & 264438 & 264073 & & 7394 & 6748 & & 39,13 & & \\
\hline 2 & nativ & 223545 & 223180 & 240222 & 3751 & 3105 & 4766 & 71,88 & & \\
\hline 3 & nativ & 233777 & 233412 & & 5092 & 4446 & & 52,50 & & \\
\hline 7 & +Ehel & $7187^{\circ}$ & 6822 & & 3708 & 3062 & & 2,23 & $4,09 \%$ & \\
\hline 8 & + Ehel & 8205 & 7840 & 6622 & 3676 & 3030 & 2741 & 2,59 & $4,75 \%$ & $0,33 \%$ \\
\hline 9 & +Ehel & 5568 & 5203 & & 2777 & 2131 & & 2,44 & $4,48 \%$ & \\
\hline $\begin{array}{l}\text { leer } 1 \\
\text { leer } 2 \\
\text { leer } 3\end{array}$ & & $\begin{array}{l}418 \\
410 \\
267\end{array}$ & & & $\begin{array}{l}804 \\
755 \\
379\end{array}$ & & & & & \\
\hline
\end{tabular}

\subsubsection{CCRF-CEM}

Die Zelllinie CCRF-CEM ist eine humane lymphoblastoide Zelllinie von einem 4Jährigen mit akuter lymphatischer T-Zell-Leukämie (T-ALL). Der Mittelwert der Luciferase-Expression mit nativem pCMVluc betrug 363932 RLU. Die mittlere Reparaturkapazität lag mit 20,47\% bei einer Standardabweichung von 1,64 \% im Bereich der Wildtypzelllinien GM03715 und AG10107. 
Tabelle 18: Messwerte für CCRF-CEM

\begin{tabular}{|c|c|c|c|c|c|c|c|c|c|c|}
\hline 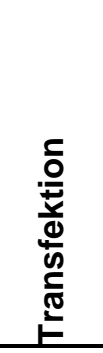 & 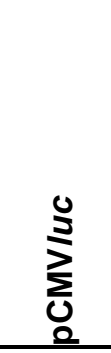 & 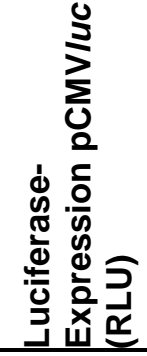 & 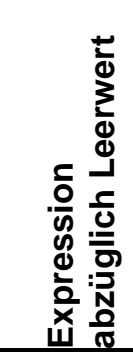 & 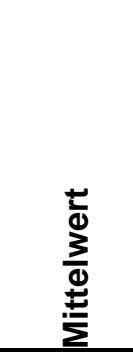 & 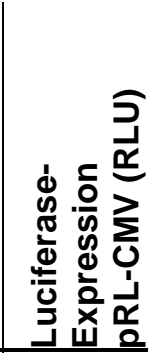 & 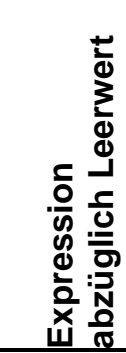 & 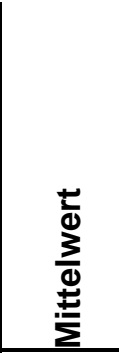 & 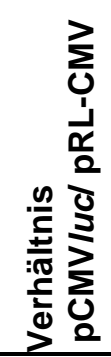 & 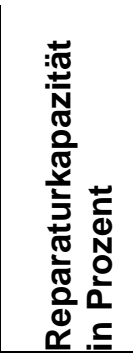 & 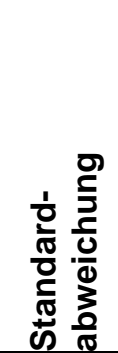 \\
\hline 1 & nativ & 284878 & 284216 & & 90572 & 89537 & & 3,17 & & \\
\hline 2 & nativ & 398710 & 398048 & 363929 & 10626 & 9591 & 38304 & 41,50 & & \\
\hline 3 & nativ & 410185 & 409523 & & 16820 & 15785 & & 25,94 & & \\
\hline 4 & +Ehel & 79241 & 78579 & & 19003 & 17968 & & 4,37 & $18,58 \%$ & \\
\hline 5 & +Ehel & 72330 & 71668 & 71488 & 15336 & 14301 & 14979 & 5,01 & $21,29 \%$ & $1,64 \%$ \\
\hline 6 & +Ehel & 64878 & 64216 & & 13704 & 12669 & & 5,07 & $21,53 \%$ & \\
\hline $\begin{array}{l}\text { leer } 1 \\
\text { leer } 2 \\
\text { leer } 3\end{array}$ & & $\begin{array}{l}649 \\
669 \\
667\end{array}$ & & & $\begin{array}{l}861 \\
1050 \\
1194\end{array}$ & & & & & \\
\hline
\end{tabular}

\subsubsection{Gesamtübersicht der Zelllinien}

Mit dem HCR-Test kann die funktionelle DSB-Reparaturkapazität der verschiedenen Zelllinien verglichen werden. In Abbildung 12 ist die Reparaturkapazität als relative Luciferase-Expression in \% der Expression mit nativem Plasmid dargestellt. Dabei sind die Ergebnisse der AML-Zelllinie Kasumi-1 sowie der Lymphomzellinie SUDHL-4 signifikant erniedrigt (in Abbildung 12 mit * markiert). Die Expressionswerte der CML-Zelllinie K562 und der T-Zell-Leukämie CCRF-CEM liegen im Bereich der Wildtypzelllinie GM03715. 


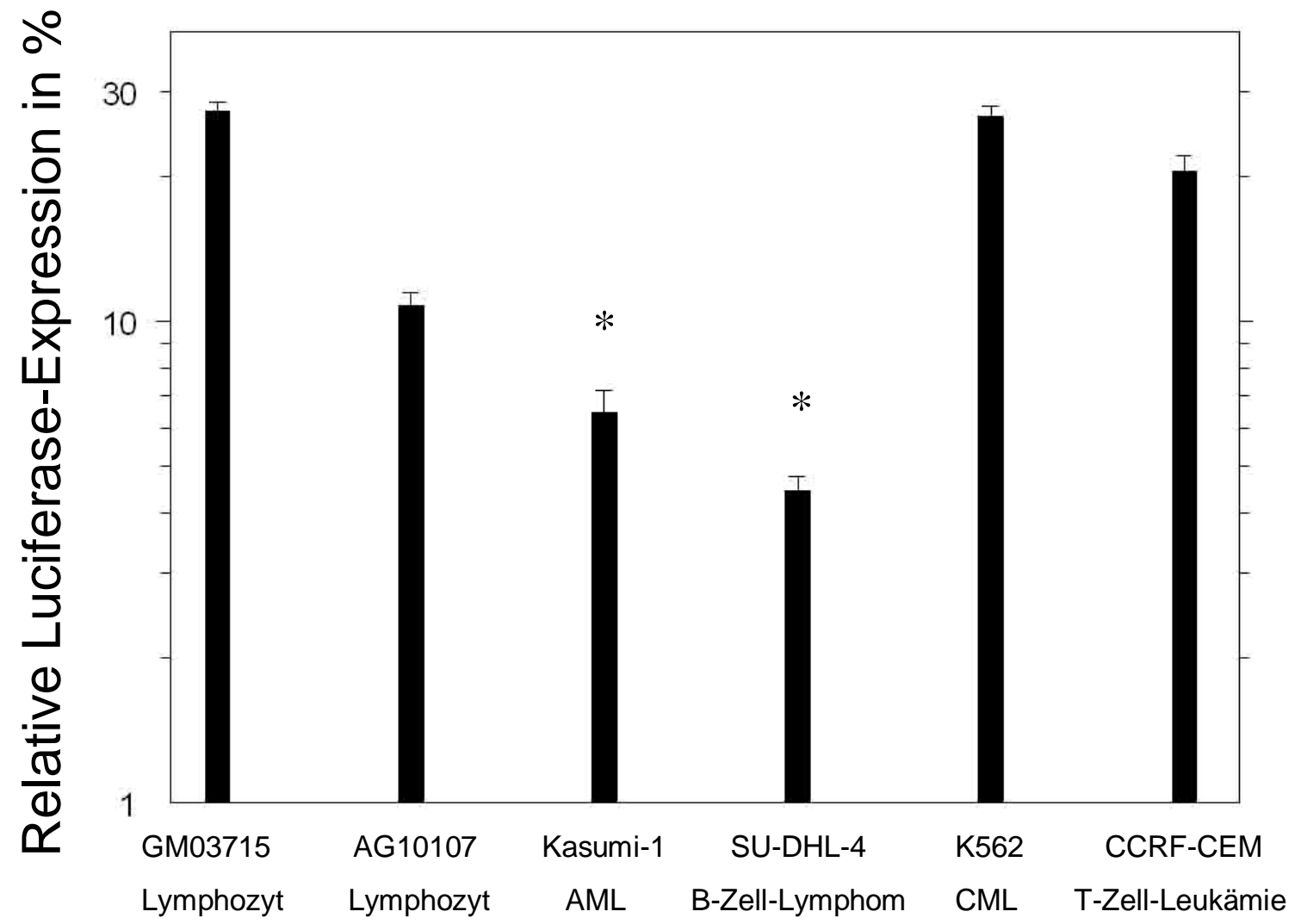

Abbildung 12: DSB-Reparaturkapazität als relative (Firefly-)Luciferase-Expression von linearisiertem pCMVluc verglichen mit nativem Plasmid. Der HCR-Test bestimmt durch Messung der Enzymaktivität der Firefly-Luciferase die Leistungsfähigkeit der Zellen, das linearisierte Plasmid pCMVluc zu religieren und zu exprimieren. Alle Werte wurden auf die Renilla-Luciferase-Expression normalisiert. In der Grafik sind der Mittelwert und die Standardabweichung von mindestens 3 unabhängigen Transfektionen dargestellt.* Die Reparaturkapazitäten der Zelllinien Kasumi-1 und SUDHL-4 sind signifikant gegenüber den Wildtypzelllinien GM03715 und AG10107 erniedrigt $(p<0,05)$. 


\section{Diskussion}

\subsection{Doppelstrangbruchreparatur und Leukämien}

Chromosomale Veränderungen, insbesondere Translokationen und Deletionen, sind typische Kennzeichen von Leukämien (Pedersen-Bjergaard et al. 2002; Rassool 2003). Häufig liegen diese im Bereich von Genen, welche für die genetische Integrität verantwortlich sind. Dazu gehören unter anderem auch die an der Doppelstrangbruchreparatur beteiligten Gene (Riballo et al. 2001; Gaymes et al. 2002a). Es gibt stetig zunehmende Hinweise über den engen Zusammenhang von Leukämien und Defekten in der Doppelstrangbruchreparatur.

Doppelstrangbrüche können durch endogene Faktoren wie freie Radikale oder Einzelstrangbrüche des parentalen Strangs in der S-Phase der Mitose entstehen. Auch verschiedene exogene DNA-schädigende Einflüsse sind als Auslöser identifiziert worden. Beispiele hierfür sind ionisierende Strahlen und Chemotherapeutika wie zum Beispiel Topoisomerase-II-Inhibitoren oder Bleomycin.

Dies zeigt sich unter anderem in Studien nach den Atombombenabwürfen in Japan 1945. Leukämien machen mit etwa 4\% nur einen geringen Anteil aller Tumore aus. Dieser Anteil stieg nach den Atombomben in Hiroshima und Nagasaki auf über 20\% (Preston et al. 1994). Dabei steigt das Erkrankungsrisiko exponentiell mit der Strahlendosis. Bei 1,0 Sv besteht ein 20-faches Risiko verglichen mit einer Dosis von 0,1 Sv (Pierce DA et al. 1996).

Auch bei der t-AML gibt es spezifische, genau bekannte Agenzien, die zu der Entstehung der sekundären AML beitragen und deren AML-induzierende Wirkung ebenfalls dosisabhängig steigt.

Eine der bestuntersuchten Medikamentengruppen im Bezug auf ihre kanzerogene Wirkung sind Topoisomerase-Hemmer, zu denen unter anderem Etoposid, Doxorubicin und Mitoxantron zählen. Etoposid ist häufiger Bestandteil einer Chemotherapie bei Malignomen.

Die Topoisomerase ist ein Enzym, welches transient die DNA spaltet, linearisiert und wieder verschließt, um überspiralisierte bzw. unterspiralisierte DNA-Formierungen zu 
ändern (Lüllmann et al. 2006). Oben genannte Inhibitoren verhindern die Religation der DNA, sodass Strangbrüche zurückbleiben. Durch Anhäufung dieser Schäden wirkt diese Medikamentengruppe apoptotisch und damit antineoplastisch (Hande 1998).

Neben dieser gewünschten Wirkung zeigt sich allerdings eine erhöhte Rate an Translokationen und es kommt gehäuft zu therapieassoziierten Leukämien, da die Topoisomerase-Hemmer bevorzugt an spezifischen Regionen, zum Beispiel dem MLL-Gen-Locus, Doppelstrangbrüche und damit Translokationen induzieren. Dass dieser Effekt auf die Medikamentenwirkung zurückzuführen ist und unabhängig von den individuellen Reparaturkapazitäten ist, konnten beispielsweise Studien von Libura et al. zeigen. In einem in-vitro-System traten in primären Blutzellen vermehrt stabile MLL-Rearrangements auf (Libura et al. 2005).

Auch Bleomycin, ein interkalierendes Chemotherapeutikum, verursacht vermehrt Doppelstrangbrüche. Li et al. zeigten, dass Zelllinien mit homozygoten Defekten verschiedener Reparaturgene (BLM, ATR, DNA-PK $K_{C S}, B R C A 1, B R C A 2, R A D 50$ und MRE11) eine erhöhte Sensitivität auf Bleomycin aufweisen (Li et al. 2004).

Da sich de-novo-AML und therapieassoziierte AML in Bezug auf Pathologie, Molekularbiologie und Zytogenetik in vielen Aspekten ähneln, darf man entsprechende Entstehungsmechanismen vermuten (Pedersen-Bjergaard et al. 2002). Jedoch ist die Menge an zeitgleichen genotoxischen Schäden durch Chemotherapie und Bestrahlung bei der t-AML um ein vielfaches erhöht. Hier zeigen die Untersuchungen der Arbeitsgruppe um Seedhouse, dass möglicherweise Defizienzen der DNA-Reparaturenzyme (in diesem Fall der Doppelstrangbruchreparatur) synergistisch wirken (Seedhouse et al. 2004). Allerdings wies die Gruppe lediglich Polymorphismen der an der DNA-DSBReparatur beteiligten Gene nach, ohne dass funktionelle Defizite untersucht wurden. Polymorphismen sind genomische Variationen und können die Proteinfunktion, die Promotoraktivität sowie die mRNA-Stabilität beeinflussen oder zu anderen SpliceVarianten führen. Polymorphismen von Genen, welche Enzyme der Doppelstrangbruchreparatur codieren, können, wie erwähnt, mit einem erhöhten Risiko für $A M L$ und insbesondere $t-A M L$ assoziiert sein. Seedhouse et al. konnten einen signifikant erhöhten Anteil an Personen mit RAD51-und XRCC3Polymorphismen bei AML-Erkrankten im Vergleich zur Kontrollgruppe feststellen 
(Seedhouse et al. 2004). Der Anteil dieser Varianten war in der Gruppe der Patienten mit t-AML noch höher. Gerade in Anbetracht der Tatsache, dass Knockout-Systeme für RAD51 (ein zentrales Protein der HR) embryonal letal sind (Tsuzuki et al. 1996), lässt sich die Vermutung aufstellen, dass zwar leichte Veränderungen im Proteinlevel oder in der Proteinaktivität von den Zellen toleriert werden, diese aber einen deutlich negativen Effekt bei starker DNA-Schädigung haben.

Für eine verminderte Reparaturkapazität müssen die Proteinkonzentrationen dabei nicht zwangsläufig erniedrigt sein. Eine Überexpression von RAD51 zeigt einen dominant-negativen Effekt auf die Initiation der HR (Kim et al. 2001). Nach einer zweiten Hypothese von Seedhouse und Kollegen hinsichtlich der erhöhten Leukämierate bei Patienten mit RAD51-Polymorphismus könnten erhöhte RAD51Level auch die Einleitung der Apoptose hemmen, sodass Zellen mit geschädigter DNA überleben und damit erworbene Mutationen und chromosomale Aberrationen an die Tochterzellen weitergegeben werden (Seedhouse et al. 2004).

Die Arbeitsgruppen um Jawad und Rollinson fanden ebenfalls ein erhöhtes Risiko für AML-Erkrankungen bei Polymorphismen im RAD51-Gen (Jawad et al. 2006; Rollinson et al. 2007). Für das Protein LigaseIV konnte ein Polymorphismus nachgewiesen werden, der allerdings einen protektiven Effekt bzgl. des AML-Risikos und der Lymphomentstehung hatte (Roddam et al. 2002; Hill et al. 2006).

Da Polymorphismen lediglich Basenveränderungen in den entsprechenden Genen angeben, kann nur indirekt auf den Effekt geschlossen werden. Sie lassen jedoch keine direkte funktionelle Aussage zu. Insbesondere die Konsequenzen der Polymorphismen in den Enzymen der Doppelstrangbruch-Reparatur sind bisher unbekannt (Seedhouse und Russell 2007). Hier ist der HCR-Test eine optimale funktionelle Ergänzung.

Mit unserem plasmidbasierten HCR-Testsystem ließ sich eine reduzierte (bzw. vermehrt fehlerhafte) DSB-Reparatur, d.h. eine funktionelle Defizienz in Zellen mit hämatologischen Neoplasien nachweisen. Dass der Test auch mit primären Blutlymphozyten möglich ist, konnte gezeigt werden (Thoms et al. 2007).

Ein zukünftiger praktischer Einsatz dieses Testsystems könnte beispielsweise die exvivo-Untersuchung der DSB-Reparaturkapazität von Individuen vor Chemotherapie zur Vorhersage des individuellen t-AML-Risikos sein. Mit Etablierung des 
Testsystems in primären Blutlymphozyten und dem erfolgreichen Einsatz in Tumorzelllinien sind dazu wichtige Voraussetzungen erfüllt.

\subsection{Wirtszell-Reaktivierungs-Test als geeignete Funktionsuntersuchung für die Messung der Reparaturfähigkeit}

DNA-Schäden und folgende DNA-Reparatur sind entscheidend für die Erhaltung genomischer Integrität und Stabilität. In der Bevölkerung besteht durch genetische Vielfalt eine individuelle DNA-Reparaturkapazität und viele Studien konnten eine Assoziation zwischen verminderter (beziehungsweise veränderter) DNAReparaturfähigkeit und Prädisposition verschiedenster Tumore, unter anderem Brustkrebs, zeigen (Shin et al. 2008; El-Zein et al. 2009). Bei vielen dieser Testsysteme lässt sich jedoch nur indirekt auf die funktionelle Reparaturkapazität schließen, beispielsweise bei Polymorphismenstudien.

Mit dem in dieser Arbeit etablierten und verwendeten Testsystem wurde die zelluläre Doppelstrangbruch-Reparaturfähigkeit hämatopoetischer Zellen unter solchen Bedingungen untersucht, die eine funktionelle Analyse der Reparaturkapazität erlauben. Es ließ sich der direkte Erfolg der korrekten DSB-Reparatur durch den Nachweis des reparaturabhängigen Luciferase-Enzyms zeigen (Thoms et al. 2007). Besonderer Vorteil ist neben der verminderten Menge an benötigten Zellzahlen auch die deutlich verkürzte Versuchszeit. Diese ist mit 3 Tagen nur ein Bruchteil der Versuchsdauer verglichen mit dem 14-tägigen Testsystem von Philips und Morgen (Phillips und Morgan 1994). Auch das CAT-System ist zwar zuverlässig, allerdings an die Nutzung radioaktiver Marker gebunden (Athas et al. 1991). Diem und Rünger nutzten linearisiertes Plasmid, um in einem Shuttle-Vektor-Test die Reparaturfähigkeit von squamösen Karzinomzellen der Haut zu bestimmen. Dabei war auch diese Methode aufgrund der Abhängigkeit von Zelltransfektion und anschließender bakterieller Transformation deutlich aufwendiger und fehleranfälliger (Diem und Rünger 1997). Der hier verwendete Test erfüllt durch seine geringen Zellmengen, relativ kurze Versuchszeit, Zuverlässigkeit und Verzicht auf radioaktive Marker alle Voraussetzungen für Populationsstudien in primären Zellen. Ein weiterer Vorteil ist die Minimierung zytotoxischer Effekte verglichen mit Studien, bei denen DNA-Schäden direkt in die Zelle gesetzt werden. Dadurch verringert sich die Gefahr ungewollter Einflüsse auf das Reparatursystem (Berwick und Vineis 2000). 


\subsection{Etablierung des Testsystems in primären Blutlymphozyten}

Die Versuche mit primären Blutlymphozyten zeigten, dass das Luciferase-TestSystem sehr sensitiv ist und bei schwer zu transfizierenden Zellen eingesetzt werden kann. Mit Lichtemissionen, die etwa 2000-fach über dem Hintergrund lagen, lassen sich mit primären Blutlymphozyten nach 3-tägiger Kultur verlässliche, hochsignifikante Werte erzielen $(p<0,01)$.

Auch Ramos et al. nutzten ein fast identisches System mit primären Blutlymphozyten von Brustkrebspatientinnen (Ramos et al. 2004) genauso wie Shin et al. 2008. In letztgenannter Studie wurde neben der Messung der DNA-Reparaturkapazität mittels HCR-System eine Bestimmung von 17 Polymorphismen in 10 Genen (unter anderem ATM und Rad51 als Vertreter der DSB-Reparatur) vorgenommen (Shin et al. 2008). Hier zeigten sich sowohl bei ATM als auch bei RAD51 eine Korrelation zwischen genetischem Polymorphismus und verminderter Reparaturkapazität in Gruppe der Brustkrebspatientinnen.

\subsection{Etablierung des Testsystems in Tumorzellen von Patienten}

Über die Nutzung des HCR-Tests zur Untersuchung von DSB-Reparatur in Leukämiezellen gibt es bisher kaum Veröffentlichungen. Dabei gibt es zahlreiche Hinweise für den Zusammenhang zwischen Polymorphismen der an der DSBReparatur beteiligten Enzyme und Leukämie-Entstehung insbesondere bei der AML und t-AML (siehe 4.1 und 4.4.1).

Für andere Reparatursysteme, beispielsweise Nukleotid-Exzisions-Reparatur nach UV-Bestrahlung, ist dieses System längst eine Routinemethode. Diem und Rünger nutzten beispielsweise linearisiertes Plasmid im Shuttle-Vektor-Methode in Plattenepithelkarzinomzellen (Diem und Rünger 1997).

Gaymes und Brady inkubierten in ihrem Versuchsdesign Kernextrakte von Leukämiezelllinien, Leukämiepatienten und Kontrollen (CD34+ Zellen sowie PBL) mit linearisiertem Plasmid und analysierten die Schnittstellen, wobei sie ein erhöhtes Mutationsspektrum in den Kernextrakten der Leukämiezelllinien fanden (Gaymes et al. 2002b; Brady et al. 2003). Diese Versuche wurden jedoch nicht in vitalen Zellen 
durchgeführt. Der in unserer Arbeit genutzte Test lässt dagegen eine funktionelle Analyse der Reparaturkapazität in der vitalen Zelle zu.

\subsubsection{Die AML-Zelllinie Kasumi-1 zeigt eine signifikant erniedrigte Reparaturkapazität}

Wie in Abbildung 12 und Tabelle 15 dargestellt, ist die Reparaturfähigkeit der Leukämiezelllinie Kasumi-1 mit einer mittleren Reparaturkapazität von 6,44\% signifikant gegenüber den Wildtypzelllinien AG10107 bzW. GM03715 erniedrigt $(p=0,002$ bzw. $p<0,001$, siehe Tabelle 15 und Abbildung 12). Dies steht in Einklang mit der allgemein anerkannten Meinung, dass eine verminderte bzw. fehlerhafte DSB-Reparatur mit dem gehäuften Auftreten von Translokationen und einem erhöhten Leukämierisiko assoziiert ist (Rassool 2003). Dieser Zusammenhang wurde erstmals im Jahr 1999 von Spencer und Ganter beschrieben, welche AML-, CMLund Kontrollzelllinien mit bis zu 100 Gy bestrahlten und die Anzahl der BCR-ABLFusionsgene via PCR und Nested-PCR bestimmten (Spencer und Granter 1999). Dabei war die Menge an BCR-ABL-Fusionsprodukten in den AML-Zelllinien signifikant höher als in den Kontrollzelllinien. Diese Translokationen interpretierte sie als Hinweis auf vermehrt fehlerhafte DNA-Reparatur. Außerdem nahm die Fusionsproduktmenge mit steigender Strahlendosis zu. Der Nachteil der Methode ist jedoch, dass die Zahl der DSB pro Zelle nicht definiert werden kann. Darüber hinaus fehlt der Nachweis der funktionellen Konsequenz dieser Fusionsereignisse.

Sequenziert und analysiert man die Fusionsregion von Translokationen, weisen diese Mikrohomologien von bis zu 7 Basenpaaren sowie Deletionen und Duplikationen auf (Yoshida et al. 1995; Betti et al. 2001). Diese Mikrohomologien sind ein typisches Kennzeichen des NHEJ (Gaymes et al. 2002a; Varga und Aplan 2005). Trotz dieser „Signatur“ des NHEJ an den Fusionsregionen weiß man bisher nur wenig über die Entstehungsmechanismen von Translokationen und es gibt einige widersprüchliche Forschungsergebnisse, die sowohl verminderte als auch gesteigerte NHEJ-Aktivität im Zusammenhang mit Chromosomeninstabilität nachweisen. So zeigen Knock-out-Modelle für Komponenten des NHEJ die protektive Bedeutung dieser Proteine gegenüber genetischer Instabilität und Tumorentstehung (Ferguson et al. 2000; Pierce AJ und Jasin 2001). Demgegenüber 
stehen einige Studien, in denen auch reparaturkompetente Zellen chromosomale Rearrangements aufweisen, wenn sie mit einer Anhäufung von DSB konfrontiert sind (Richardson und Jasin 2000).

In zwei Studien stellten sowohl Gaymes als auch Brady eine erhöhte NHEJ-Aktivität in Leukämiezelllinien fest (Gaymes et al. 2002a; Brady et al. 2003). Diese Ergebnisse erscheinen auf den ersten Blick widersprüchlich zu den Ergebnissen dieser Arbeit. Allerdings inkubierten die Arbeitsgruppen in ihrem Versuchsdesign Kernextrakte von Leukämiezelllinien, Leukämiepatienten und Kontrollen (CD34+ Zellen sowie PBL) mit linearisiertem Plasmid (mit 4bp-Überhängen an den Bruchenden). Dabei waren die signifikant erhöhten Ligationseffizienzen der Leukämiezelllinien und primären Leukämiezellen mit einer erhöhten Fehlerquote (insbesondere vermehrten großen Deletionen von bis zu 400 bp) verbunden, während bei den Kontrollen nur kleinere Deletionen auftraten ( $<28 \mathrm{bp}$ ). Diese Ergebnisse sagen jedoch wenig über funktionelle Eigenschaften des religierten Plasmids aus. Größere Deletionen könnten einen Expressionsverlust des Luciferasegens bzw. Funktionsverlust der Luciferase bewirkt haben. Diese funktionelle Konsequenz wurde von den Arbeitsgruppen nicht untersucht. In unseren Versuchen könnte bei der AML-Zelllinie Kasumi-1 eine zwar vermehrte, aber fehlerhafte DSB-Reparatur aufgetreten sein, welche letztlich nicht zu einer funktionsfähigen Luciferasebildung geführt hat.

Des Weiteren besteht eine bessere Religationseffizienz bei Doppelstrangbrüchen mit Basenüberhängen, sodass die Nutzung unterschiedlicher Restriktionsenzyme (4bpÜberhänge vs. glatte Enden) ebenso wie unterschiedliche Testumgebungen (Kernextrakt vs. intakte Zelle) einen Einfluss auf die Ergebnisse haben könnten (Baumann und West 1998; Daley und Wilson 2005). Deshalb passen diese auf den ersten Blick widersprüchlichen Ergebnisse einer gesteigerten (fehlerhaften) DSBReparatur auf DNA-Ebene und einer reduzierten funktionellen DSBReparaturkapazität durchaus zusammen.

Dabei scheinen Ku70 und Ku86 als Komponenten des NHEJ an der erhöhten Fehlerrate beteiligt zu sein (Gaymes et al. 2002a; Brady et al. 2003). Knock-outMäuse für Ku70 und Ku86 zeigen ebenfalls eine erhöhte chromosomale Instabilität, Wachstumsretardierung und schwere kombinierte Immundefizienz (aufgrund beeinträchtigter $V(D) J-R e k o m b i n a t i o n)$, sodass sowohl eine gesteigerte als auch eine 
fehlende Aktivität zu genetischer Instabilität führt (Rassool 2003). Diese Theorie wird durch die Tatsache gestützt, dass es keine vergleichbare Erkrankung beim Menschen gibt, sondern diese vermutlich embryonal letal sind (Khanna und Jackson 2001).

Ein weiterer Beleg für die Bedeutung von Defizienzen des DSB-Reparatursystems bei der Leukämieentstehung findet sich bei Reparaturdefizienzsyndromen, wie beispielsweise der Fanconi-Anämie (Tischkowitz und Dokal 2004).

Die Fanconi-Anämie (FA) ist ein angeborenes Knochenmarksinsuffizienz-Syndrom und umfasst mittlerweile mindestens 13 Komplementationsgruppen: FANC-A, FANCB, FANC-C, FANC-D1 (entspricht BRCA2), FANC-D2, FANC-E, FANC-F, FANC-G, FANC-I, FANC-J, FANC-L, FANC-M and FANC-N. 68\% der deutschen FA-Patienten weisen eine Mutation des FANC-A-Gens auf (Rosenberg et al. 2008). Bereits bei Geburt fallen die Patienten durch Kleinwuchs, skelettale Fehlbildungen (beispielsweise Daumen-/Radiushypoplasie), Hautverfärbungen (insbesondere Café au lait-Fecken und Hypopigmentierungen), Mikrophthalmie sowie renale oder intestinale Fehlbildungen auf. Später treten ein progredientes Knochenmarksversagen mit den klinischen Folgen der Panzytopenie sowie eine deutlich erhöhte Rate an Tumorerkrankungen, insbesondere akuter myeloischer Leukämie, in den Vordergrund.

FA-Zellen zeichnen sich durch eine erhöhte chromosomale Empfindlichkeit gegenüber interkalierenden Substanzen wie Mitomycin C sowie Diepoxybutan aus, welche durch den Nachweis vermehrter Chromosomenbrüche zur Diagnostik eingesetzt werden können (Tischkowitz und Dokal 2004).

Verschiedene Studien (Escarceller et al. 1998; Donahue und Campbell 2002) konnten zeigen, dass die verantwortlichen FA-Proteine mit anderen DSBReparaturproteinen (NBS1, ATM) interagieren und somit beim NHEJ beteiligt sind. Des Weiteren gibt es Hinweise für einen fehlerhaften Kontrollpunkt-Arrest, abnorm regulierte Apoptosewege, Defekte in der Telomerstabilität sowie veränderte Level an Wachstumsfaktoren. Dies könnte der Grund für die Tatsache sein, dass im Vergleich zu anderen genetischen Instabilitäts-Syndromen zwar ebenfalls vermehrt Krebserkrankungen auftreten, aber zusätzlich noch das Versagen des Knochenmarks ein einzigartiges Merkmal darstellt. Dabei spielen FA-Proteine vermutlich eine bedeutende Rolle für das Überleben der hämatopoetischen 
Stammzellen. Insbesondere die Telomerinstabilität und die erhöhte Apoptoserate führen zu einem Knochenmarksversagen. Zusätzlich kommt es zu einem Selektionsdruck, welcher durch gestörten Kontrollpunkt-Arrest und fehlerhafter DNAReparaturwege zu einem stark erhöhten Risiko für die Entstehung eines Apoptoseresistenten Klons beiträgt. Klinisch zeigt sich dies in einer Häufung von hämatoproliferativen Erkrankungen, wie AML und myelodysplastischem Syndrom (Tischkowitz und Dokal 2004).

Ein weiteres Beispiel für die Bedeutung einer funktionierenden DSB-Reparatur zum Schutz vor Leukämieerkrankungen ist das Ligase-IV-Syndrom. Missense-Mutationen im Ligase-IV-Gen konnten mit einem Syndrom assoziiert werden, welches sich durch erhöhte Radiosensitivität, Immundefizienz, Panzytopenie, Mikrokephalie sowie verschiedene Entwicklungsstörungen auszeichnet. Die Mutationen auf Chromosom 13q33-q34 führt zu einer verminderten Bindungsfähigkeit der Ligase-IV, welche eine wichtige Rolle beim NHEJ spielt. Dabei hängt die Schwere der Erkrankung von der Restaktivität ab (Wei YF et al. 1995). Von den wenigen betroffenen Patienten sind überdurchschnittlich viele an Leukämie erkrankt (McKinnon und Caldecott 2007). Die Fähigkeit des Ligase-IV-XRCC4-Komplexes, freie DNA-Enden vor dem Abbau zu schützen, könnte zur korrekten Religation der Enden beitragen, so dass eine verminderte Aktivität Rearrangements fördert (Smith J et al. 2003).

Auch bei Untersuchungen der Zelllinie 180BR, welche ebenfalls einen Defekt der Ligase-IV aufweist, ist das D-NHEJ eingeschränkt und DSB werden vermehrt über das langsamere B-NHEJ repariert. Dies könnte durch eine verlängerte Persistenz und damit vermehrte Zahl von DSB zu einem Zeitpunkt die erhöhte Strahlenempfindlichkeit und Leukämieneigung erklären (Wang H et al. 2001). Zudem waren Knock-out-Mäuse bzgl. der Ligase-IV embryonal lethal (Barnes et al. 1998) und es gibt keine bekannten Patienten mit biallelischem Funktionsverlust der LigaseIV (Chistiakov et al. 2009), was ebenfalls für die essentielle Bedeutung einer funktionierenden Doppelstrangbruchreparatur spricht.

Insgesamt erscheinen der Synergismus und möglicherweise eine individuell begrenzte Reparaturkapazität der an der DSB-Reparatur beteiligten Gene für die genetische Integrität entscheidend zu sein. Hierunter erklärt sich die Häufung gewisser Polymorphismen in t-AML-Populationen, welche zwar für die reguläre DSB- 
Reparatur ausreichend sein könnten, jedoch versagen, wenn eine Zelle mit einer erhöhten Zahl von DSB, beispielsweise im Rahmen einer Chemotherapie, konfrontiert wird (Seedhouse et al. 2004).

\subsubsection{Die CML-Zelllinie K562 zeigt keine verminderte DSB-Reparaturkapazität}

Die Zelllinie K562 wurde von einem Patienten mit CML in Blastenkrise gewonnen. Die Reparaturkapazität lag dabei mit einem mittleren Wert von 26,66\% im Bereich der Wildtypzelllinie GM03715 (siehe Tabelle 16 und Abbildung 12).

Bei über 90\% der CML-Erkrankten gelingt der Nachweis des BCR-ABL-Onkogens, welches durch eine reziproke Translokation zwischen den Chromosomen 9 und 22 verursacht wird (Shet et al. 2002). Zudem weisen insbesondere CML-Zellen in Blastenkrise vermehrt Translokationen auf, sodass eine Akkumulation von Mutationen für die Progression der Erkrankung in Richtung Blastenkrise ursächlich erscheint (Penserga und Skorski 2007).

Die Bedeutung der BCR-ABL-Translokation für die Entstehung und den Progress der CML ist Gegenstand vieler Studien mit zum Teil widersprüchlichen Ergebnissen. Das Protein der BCR-ABL-Fusion ist eine dauerhaft aktivierte Tyrosinkinase, welche eine deutlich verminderte Apoptoserate sowie eine Proliferation ohne Einfluss externer Wachstumsfaktoren bewirkt (Melo et al. 2001; Shet et al. 2002). Zudem konnte eine verlängerte Aktivierung von Zellzyklus-Kontrollpunkten dargestellt werden (Slupianek et al. 2006; Penserga und Skorski 2007).

Nachgewiesen ist auch die erhöhte Produktion reaktiver Sauerstoffspezies in BCRABL-positiven Zellen, welche insbesondere DNA-DSB verursachen (Sattler et al. 2000; Nowicki et al. 2004). Wie diese jedoch genau entstehen ist unklar (Sallmyr et al. 2008).

Dabei scheint die Anzahl der DSB in einer Zelle zu einem Zeitpunkt für die Translokationshäufigkeit von Bedeutung zu sein. Auch bei reparaturkompetenten Zellen reichen bereits zwei DSB für eine 2000-fache Steigerung der Translokationsrate aus (Richardson und Jasin 2000). Ebenfalls zeigen WildtypZelllinien nach Hochdosis-Bestrahlung (80 Gy mit 23 Gy/min) in 50\% eine fehlerhafte Korrektur der DSB, während bei niedriger Strahlung über einen längeren Zeitraum (bei gleicher Enddosis) kaum fehlerhafte Reparaturen auftreten (Rothkamm et al. 
2001). Rothkamm et. al spekulieren, dass die Wahrscheinlichkeit einer Translokation mit Anzahl und Nähe dieser Doppelstrangbrüche zueinander zunimmt.

Hierzu passt, dass verschiedene Arbeitsgruppen eine vermehrte Aktivität von HR und NHEJ darstellen konnten (Gaymes et al. 2002a; Nowicki et al. 2004). Vermehrte Doppelstrangbrüche könnten eine Aktivierung der Reparaturkaskaden bewirkt haben (Slupianek et al. 2006).

Daneben gibt es einige Untersuchungen zum Einfluss des BCR-ABL-Onkogens auf die Doppelstrangbruchreparatur. Mehrere Arbeitsgruppen konnten Einschränkungen der verschiedenen Doppelstrangbruchreparaturwege durch die BCR-ABL-Kinase (Penserga und Skorski 2007; Cramer et al. 2008) darstellen. Über welchen Mechanismus dies geschieht, bleibt jedoch kontrovers (Dierov et al. 2009). So scheint die HR vermehrt fehlerbehaftet zu sein (Slupianek et al. 2006). Arbeitsgruppen um Nowicki und Gaymes zeigten eine gesteigerte Zahl an Reparationsprodukten mit Signatur des NHEJ (Mikrohomologien), wobei die Deletionen in CML-Proben größer als in den Wildtypzelllinien waren (Gaymes et al. 2002a; Nowicki et al. 2004). Dagegen fanden Deutsch et. al. eine verminderte DNAPKcs-Aktivität in CML-Zellen (Deutsch et al. 2001).

Zudem zeigten Sallmyr et al. kürzlich, dass die genomische Instabilität in CML-Zellen dadurch gefördert wird, dass vermehrt der alternative Weg des B-NHEJ beschritten wird. Dabei ist die Aktivität der Ligase-IV sowie des Artemis-Proteins deutlich erniedrigt (Sallmyr et al. 2008). Da das B-NHEJ eine deutlich langsamere Kinetik aufweist, wird die Zahl der zeitgleich vorliegenden freien DNA-Enden noch einmal gesteigert, was die vermehrten Translokationen erklären könnte (DiBiase et al. 2000; Iliakis et al. 2004).

Unsere Ergebnisse unterstreichen dagegen die Vermutung, dass bei der CML in der Blastenkrise die funktionelle DSB-Reparaturkapazität nicht eingeschränkt ist. Möglicherweise sind die erhöhte Zahl an DSB zu einem Zeitpunkt sowie die gestörten Apoptose- und Zellzyklus-Kontrollpunkte Hauptverursacher der genetischen Instabilität in CML-Zellen und nicht die Einschränkungen der DSBReparaturmechanismen. Insgesamt sind jedoch weitere Untersuchungen zur Klärung der Leukämogenese und des Zusammenhangs mit den DoppelstrangbruchReparatursystemen in CML-Zellen notwendig. 


\subsubsection{In der B-Zell-Lymphom-Zelllinie SU-DHL-4 ist die DSB-Reparaturkapazität signifikant erniedrigt}

Die funktionelle Messung der Zelllinie SU-DHL-4 ergibt eine mittlere Reparaturkapazität von 4,44\%, wie in Abbildung 12 und Tabelle 17 dargestellt ist. Somit zeigt sich eine signifikante Verminderung gegenüber den Wildtypzellinien AG10107 und GM03715 ( $p=0,001$ bzw. $p<0,001$, siehe Tabelle 17 und Abbildung 12).

Dieses Ergebnis passt zu der erhöhten Lymphom-Inzidenz bei Patienten mit Instabilitätssyndromen, wie beispielsweise Ataxia telangiectasia (AT) und Nijmegen Breakage Syndrom (NBS). Bei der AT liegt der Defekt im ATM (ataxia telangiectasia mutated)-Protein, welches bei DSB aktiviert wird (O'Driscoll und Jeggo 2006). Dieses könnte durch den MRE11-Rad50-NBS1-Komplex geschehen, welcher beim Nijmegen Breakage Syndrom kompromittiert ist (Falck et al. 2005). Sowohl NBS und AT sind beide charakterisiert durch lymphatische Malignome, ähnliche Muster genomischer Instabilität und erhöhte zelluläre und klinische Strahlenempfindlichkeit. Sowohl AT als auch das NBS weisen milde DNA-Reparatur-Defekte und Zell-ZyklusKontrollpunkt-Defekte auf. Diese Kombination bedingt wahrscheinlich die erhöhte Inzidenz von Lymphomen und Leukämien bei diesen Patienten. So können in Lymphomzellen häufig Translokationen gefunden werden (Elliott und Jasin 2002). Dies zeigt, dass die DSB-Reparatur nicht nur einen Defekt aufweist, sondern fehlerhaft geschieht. Dabei gibt es eine Parallele zwischen der veränderten Aktivität bzw. Restaktivität des NHEJ und dem Krebsrisiko. Im Vergleich zu reparaturkompetenten Zellen rekrutieren AT-Zellen nur 10\% der MRE11-Menge zu Orten von Strangbrüchen. Diese Menge ist in NBS-Zellen noch einmal niedriger. Gegenläufig haben NBS-Patienten das höhere Krebsrisiko (Maser et al. 1997; Digweed et al. 1999).

Da Translokationen und andere Rearrangements (Deletionen, Insertionen) früh in der Entstehung von Lymphomen auftreten, darf eine fehlerhafte DNADoppelstrangbruchreparatur vermutet werden (Hill et al. 2006). Hill konnte zeigen, dass ein Polymorphismus der Ligase-IV signifikant seltener bei Lymphom-Patienten auftritt. 
Slebos und Taylor scheiterten mit ihrem Versuch, einen HCR-Test mit einer Lymphomzelllinie zu etablieren. Die Transfektionseffizienz des Systems war zu gering, um verlässliche Aussagen zu treffen (Slebos und Taylor 2001). Bereits dort wiesen die Autoren auf die potenzielle Anwendungsmöglichkeit für die individuelle Vorhersage von DNA-Reparaturfähigkeit hin.

\subsubsection{Die Reparaturkapazität der T-Zell-Leukämie-Zelle CCRF-CEM ist nicht erniedrigt}

Die T-Zell-Leukämie ist eine Erkrankung, die in 100\% der Fälle mit dem Retrovirus HTLV-1 und der Expression des viralen Onkogens Tax assoziiert werden kann (Takatsuki 2005). Dabei lag die Reparaturkapazität der Zelllinie CCRF-CEM mit einem Mittelwert von 20,47 \% im Bereich der Wildtypzelllinien GM03715 und AG10107 (vergleiche Tabelle 18 sowie Abbildung 12).

Tax hat negative Einflüsse auf andere Reparatursysteme, insbesondere BasenExzisions-Reparatur und Nukleotid-Exzisions-Reparatur, jedoch gibt es einige Hinweise, die auch auf einen Zusammenhang mit den Komponenten des NHEJ hindeuten. So interagiert Tax wahrscheinlich mit der DNA-PKCs und führt zu einer verminderten Phosphorylierung (Durkin et al. 2008). Allerdings ist die Rolle von DNAPKcs für die korrekte DSB-Reparatur nicht eindeutig. Gaymes et al. fanden in ihrer Studie mit Zellextrakten verschiedener Zelllinien bei Zugabe von Antikörpern gegen DNA-PKcs keine Veränderung in der Religation, im Gegensatz zu Ku70 und Ku80 (Gaymes et al. 2002a).

Chen et al. untersuchten die Veränderungen von Ku80 auf RNA-Ebene in lymphatischen Tumoren. Dabei stellten sie keine Sequenz-Veränderung in der Zelllinie CCRF-CEM fest (Chen et al. 2005).

Somit müssten weitere Experimente mit verschiedenen Proben von T-ZellLeukämien klären, ob die Ergebnisse konstant für diese Entität sind.

Insgesamt weisen die Ergebnisse dieser Arbeit darauf hin, dass bei Leukämien und Lymphomen heterogene DSB-Reparaturkapazitäten vorkommen. Dabei zeigen lymphoblastoide Zellen einer T-Zell-Leukämie (CCRF-CEM) und myeloische Zellen einer chronischen Leukämie (K562) eine nicht oder nur diskrete Defizienz in der DSB-Reparatur. 
Im Gegensatz dazu sind die myeloischen Zellen einer akuten Leukämie (Kasumi-1) signifikant reparaturkompromittiert. Darüber hinaus lässt sich auch bei der B-ZellLymphom-Zelllinie SU-DHL-4 eine verminderte DSB-Reparatur zeigen.

Es werden sicherlich noch einige Studien und Untersuchungen notwendig sein, um die Ursachen und Konsequenzen einer differierenden DSB-Reparaturkapazität weiter zu verstehen. Diese Arbeit konnte mit der funktionellen Messung der DSBReparaturkapazität und dem Aufzeigen der unterschiedlichen Aktivität in einzelnen hämatologischen Neoplasien hierzu einen Beitrag liefern.

Ein langfristiges Ziel für eine mögliche Anwendung der HCR-Testsysteme wäre nach Etablierung und Optimierung in PBL der Einsatz bei Tumor-Patienten. Hier müsste prospektiv evaluiert werden, ob eine verminderte Reparaturkapazität mit einer erhöhten Inzidenz von t-AML verbunden ist. Dies könnte zur individuellen Risikovorhersage genutzt werden, um ein optimiertes Behandlungskonzept für Hochrisikopatienten zu entwickeln. 


\section{Zusammenfassung}

Veränderungen und Mängel in der individuellen Reparaturkapazität scheinen an der Entstehung von t-AML beteiligt zu sein. Polymorphismusstudien deuten an, dass zwischen de-novo- und t-AML ein Unterschied in den verschiedenen Reparatursystemen besteht. Diese Beobachtungen lassen jedoch keine Schlüsse auf die funktionellen Unterschiede zu.

Insbesondere Doppelstrangbrüche werden als kritische Primärläsion für die Entstehung von Translokationen angesehen, welche ein typisches Merkmal von Leukämien sind. Ziel dieser Arbeit war daher die Etablierung eines modifizierten HCR-Tests zur funktionellen Messung der individuellen zellulären DSBReparaturkapazität.

In unserem Testsystem wurde das Plasmid pCMVluc durch ein Enzym im Luciferasegen-tragenden Abschnitt einmalig mit glatten Enden geschnitten und mittels Gelelution aufgereinigt. Anschließend wurde das linearisierte Plasmid in Leukämie- respektive primäre Blutzellen von Patienten transfiziert, um deren funktionelle Reparaturkapazität zu untersuchen. Nur durch eine funktionierende korrekte DSB-Reparatur in der Zelle ließ sich das Plasmid so religieren, dass das pCMVluc- Gen abgelesen und Luciferaseenzym gebildet werden konnte. Dieses wurde durch die Lichtemission als lineare Korrelation der Luciferasemenge detektiert. Diese Methode wurde für die Analyse der DSB-Reparatur neu etabliert und dahingehend optimiert, dass sie in primären Blutlymphozyten funktioniert. Zudem wurde gezeigt, dass die AML-Zelllinie Kasumi-1 und die B-Zell-Lymphom-Zelllinie SU-DHL-4 eine signifikant verminderte DSB-Reparaturkapazität gegenüber den Kontrollzelllinien GM 03715 und AG 10107 aufweisen (6,44 \% \pm 0,75 \%, 4,44 \% \pm $0,33 \%$ versus $27,35 \% \pm 1,13 \%$ und $10,79 \% \pm 0,71 \%)$. Demgegenüber waren die Reparaturkapazitäten der T-Zell-Leukämie-Zelllinie CCRF-CEM und der CMLZelllinie K562 nicht erniedrigt $(20,47 \% \pm 1,64 \%$ und $26,66 \% \pm 1,25 \%)$.

Das in dieser Arbeit etablierte HCR-Testsystem ist für die Untersuchung der funktionellen Zusammenhänge zwischen t-AML Leukämogenese und veränderter DSB-Reparaturkapazität geeignet. Außerdem besteht potenziell die Möglichkeit der Bestimmung der individuellen Reparaturkapazität eines Patienten vor einer geplanten Chemotherapie, um optimierte Behandlungskonzepte für 
Hochrisikopatienten hinsichtlich der Verminderung des Auftretens von t-AML zu entwickeln. 


\section{Literaturverzeichnis}

Aflalo C (1991): Biologically localized firefly luciferase: a tool to study cellular processes. Int Rev Cytol 130, 269-323

Athas WF, Hedayati MA, Matanoski GM, Farmer ER, Grossman L (1991): Development and field-test validation of an assay for DNA repair in circulating human lymphocytes. Cancer Res $\underline{51}$, 5786-5793

Barnes DE, Stamp G, Rosewell I, Denzel A, Lindahl T (1998): Targeted disruption of the gene encoding DNA ligase IV leads to lethality in embryonic mice. Curr Biol $\underline{8}, 1395-1398$

Baumann P, West SC (1998): DNA end-joining catalyzed by human cell-free extracts. Proc Natl Acad Sci U S A $\underline{95}$, 14066-14070

Bennett JM, Catovsky D, Daniel MT, Flandrin G, Galton DA, Gralnick HR, Sultan C (1976): Proposals for the classification of the acute leukaemias. FrenchAmerican-British (FAB) co-operative group. Br J Haematol $\underline{33}$, 451-458

Bennett JM, Catovsky D, Daniel MT, Flandrin G, Galton DA, Gralnick HR, Sultan C (1985): Proposed revised criteria for the classification of acute myeloid leukemia. A report of the French-American-British Cooperative Group. Ann Intern Med 103, 620-625

Berwick M, Vineis P (2000): Markers of DNA repair and susceptibility to cancer in humans: an epidemiologic review. J Natl Cancer Inst $\underline{92}$, 874-897

Betti CJ, Villalobos MJ, Diaz MO, Vaughan AT (2001): Apoptotic triggers initiate translocations within the MLL gene involving the nonhomologous end joining repair system. Cancer Res $\underline{61}, 4550-4555$

Bradbury JM, Jackson SP (2003): The complex matter of DNA double-strand break detection. Biochem Soc Trans $\underline{31}, 40-44$

Brady N, Gaymes TJ, Cheung M, Mufti GJ, Rassool FV (2003): Increased errorprone NHEJ activity in myeloid leukemias is associated with DNA damage at sites that recruit key nonhomologous end-joining proteins. Cancer Res $\underline{63}$, 1798-1805

Brunk CF, Simpson L (1977): Comparison of various ultraviolet sources for fluorescent detection of ethidium bromide-DNA complexes in polyacrylamide gels. Anal Biochem $\underline{82}, 455-462$

Burma S, Chen BP, Chen DJ (2006): Role of non-homologous end joining (NHEJ) in maintaining genomic integrity. DNA Repair (Amst) $\underline{5}, 1042-1048$ 
Cary RB, Peterson SR, Wang J, Bear DG, Bradbury EM, Chen DJ (1997): DNA looping by $\mathrm{Ku}$ and the DNA-dependent protein kinase. Proc Natl Acad Sci U S A $\underline{94}, 4267-4272$

Chen TY, Chen JS, Su WC, Wu MS, Tsao CJ (2005): Expression of DNA repair gene Ku80 in lymphoid neoplasm. Eur J Haematol $\underline{74}$, 481-488

Chistiakov DA, Voronova NV, Chistiakov AP (2009): Ligase IV syndrome. Eur J Med Genet $\underline{52}, 373-378$

Christ O, Feuring-Buske M, Hiddemann W, Buske C (2007): Pathogenese und Biologie der akuten myeloischen Leukämie. Med Klin (Munich) 102, 290-295

Cramer K, Nieborowska-Skorska M, Koptyra M, Slupianek A, Penserga ET, Eaves CJ, Aulitzky W, Skorski T (2008): BCR/ABL and other kinases from chronic myeloproliferative disorders stimulate single-strand annealing, an unfaithful DNA double-strand break repair. Cancer Res $\underline{68}, 6884-6888$

Daley JM, Wilson TE (2005): Rejoining of DNA double-strand breaks as a function of overhang length. Mol Cell Biol 25, 896-906

de Wet JR, Wood KV, DeLuca M, Helinski DR, Subramani S (1987): Firefly luciferase gene: structure and expression in mammalian cells. Mol Cell Biol $\underline{7}, 725-737$

Deutsch E, Dugray A, AbdulKarim B, Marangoni E, Maggiorella L, Vaganay S, M'Kacher R, Rasy SD, Eschwege F, Vainchenker W (2001): BCR-ABL downregulates the DNA repair protein DNA-PKcs. Blood 97, 2084-2090

DiBiase SJ, Zeng ZC, Chen R, Hyslop T, Curran WJ, Jr., Iliakis G (2000): DNAdependent protein kinase stimulates an independently active, nonhomologous, end-joining apparatus. Cancer Res $\underline{60}, 1245-1253$

Diem C, Rünger TM (1997): Processing of three different types of DNA damage in cell lines of a cutaneous squamous cell carcinoma progression model. Carcinogenesis $\underline{18}, 657-662$

Dierov J, Sanchez PV, Burke BA, Padilla-Nash H, Putt ME, Ried T, Carroll M (2009): $\mathrm{BCR} / \mathrm{ABL}$ induces chromosomal instability after genotoxic stress and alters the cell death threshold. Leukemia $\underline{23}, 279-286$

Digweed M, Reis A, Sperling K (1999): Nijmegen breakage syndrome: consequences of defective DNA double strand break repair. Bioessays $\underline{21}, 649-656$

Donahue SL, Campbell C (2002): A DNA double strand break repair defect in Fanconi anemia fibroblasts. J Biol Chem 277, 46243-46247

Dronkert ML, Beverloo HB, Johnson RD, Hoeijmakers JH, Jasin M, Kanaar R (2000): Mouse RAD54 affects DNA double-strand break repair and sister chromatid exchange. Mol Cell Biol 20, 3147-3156 
Durkin SS, Guo X, Fryrear KA, Mihaylova VT, Gupta SK, Mehdi Belgnaoui S, Haoudi A, Kupfer GM, John Semmes O (2008): HTLV-1 Tax oncoprotein subverts the cellular DNA damage response via binding to DNA-PK. J Biol Chem $\underline{283}$, 36311-36320

El-Zein R, Monroy CM, Etzel CJ, Cortes AC, Xing Y, Collier AL, Strom SS (2009): Genetic polymorphisms in DNA repair genes as modulators of Hodgkin disease risk. Cancer $\underline{115}, 1651-1659$

Elliott B, Jasin M (2002): Double-strand breaks and translocations in cancer. Cell Mol Life Sci $\underline{59}$, 373-385

Emmert S, Slor H, Busch DB, Batko S, Albert RB, Coleman D, Khan SG, Abu-Libdeh B, DiGiovanna JJ, Cunningham BB (2002): Relationship of neurologic degeneration to genotype in three xeroderma pigmentosum group $\mathrm{G}$ patients. $\mathrm{J}$ Invest Dermatol $\underline{118}$, 972-982

Emmert S, Leibeling D, Runger TM (2006): Syndromes with genetic instability: model diseases for (skin) cancerogenesis. J Dtsch Dermatol Ges $\underline{4}, 721-731$

Escarceller M, Buchwald M, Singleton BK, Jeggo PA, Jackson SP, Moustacchi E, Papadopoulo D (1998): Fanconi anemia C gene product plays a role in the fidelity of blunt DNA end-joining. J Mol Biol 279, 375-385

Estey E (2007): Acute myeloid leukemia and myelodysplastic syndromes in older patients. J Clin Oncol 25, 1908-1915

Estey E, Döhner H (2006): Acute myeloid leukaemia. Lancet $\underline{368}$, 1894-1907

Falck J, Coates J, Jackson SP (2005): Conserved modes of recruitment of ATM, ATR and DNA-PKcs to sites of DNA damage. Nature $\underline{434}, 605-611$

Felix CA (1998): Secondary leukemias induced by topoisomerase-targeted drugs. Biochim Biophys Acta $\underline{1400}$, 233-255

Ferguson DO, Sekiguchi JM, Chang S, Frank KM, Gao Y, DePinho RA, Alt FW (2000): The nonhomologous end-joining pathway of DNA repair is required for genomic stability and the suppression of translocations. Proc Natl Acad Sci $U$ S A $\underline{97}, 6630-6633$

Fregeau CJ, Bleackley RC (1991): Factors influencing transient expression in cytotoxic $T$ cells following DEAE dextran-mediated gene transfer. Somat Cell Mol Genet 17, 239-257

Gaymes TJ, Mufti GJ, Rassool FV (2002a): Myeloid leukemias have increased activity of the nonhomologous end-joining pathway and concomitant DNA misrepair that is dependent on the Ku70/86 heterodimer. Cancer Res $\underline{62}$, 2791-2797

Gaymes TJ, North PS, Brady N, Hickson ID, Mufti GJ, Rassool FV (2002b): Increased error-prone non homologous DNA end-joining--a proposed 
mechanism of chromosomal instability in Bloom's syndrome. Oncogene 21 , 2525-2533

Gu J, Lu H, Tippin B, Shimazaki N, Goodman MF, Lieber MR (2007): XRCC4:DNA ligase IV can ligate incompatible DNA ends and can ligate across gaps. EMBO J 26, 1010-1023

Hanahan D (1983): Studies on transformation of Escherichia coli with plasmids. J Mol Biol 166, 557-580

Hande KR (1998): Etoposide: four decades of development of a topoisomerase II inhibitor. Eur J Cancer 34, 1514-1521

Harris NL, Jaffe ES, Diebold J, Flandrin G, Muller-Hermelink HK, Vardiman J, Lister TA, Bloomfield CD (1999): World Health Organization classification of neoplastic diseases of the hematopoietic and lymphoid tissues: report of the Clinical Advisory Committee meeting-Airlie House, Virginia, November 1997. J Clin Oncol 17, 3835-3849

Hill DA, Wang SS, Cerhan JR, Davis S, Cozen W, Severson RK, Hartge P, Wacholder S, Yeager M, Chanock SJ (2006): Risk of non-Hodgkin lymphoma (NHL) in relation to germline variation in DNA repair and related genes. Blood $\underline{108}, 3161-3167$

Hoeijmakers JH (2001): Genome maintenance mechanisms for preventing cancer. Nature $\underline{411}, 366-374$

Hori K, Wampler JE, Matthews JC, Cormier MJ (1973): Identification of the product excited states during the chemiluminescent and bioluminescent oxidation of Renilla (sea pansy) luciferin and certain of its analogs. Biochemistry $\underline{12}, 4463-$ 4468

Iliakis G, Wang H, Perrault AR, Boecker W, Rosidi B, Windhofer F, Wu W, Guan J, Terzoudi G, Pantelias G (2004): Mechanisms of DNA double strand break repair and chromosome aberration formation. Cytogenet Genome Res $\underline{104}$, $14-20$

Jackson SP (2002): Sensing and repairing DNA double-strand breaks. Carcinogenesis $\underline{23}, 687-696$

Jawad M, Seedhouse CH, Russell N, Plumb M (2006): Polymorphisms in human homeobox HLX1 and DNA repair RAD51 genes increase the risk of therapyrelated acute myeloid leukemia. Blood 108, 3916-3918

Johnson RD, Jasin M (2000): Sister chromatid gene conversion is a prominent double-strand break repair pathway in mammalian cells. EMBO J $\underline{19}$, 33983407

Karran P (2000): DNA double strand break repair in mammalian cells. Curr Opin Genet Dev 10, 144-150 
Kern W, Behre G, von Schilling C, Haferlach T, Adorf D, Jehn U, Waterhouse C, Brack N, Schnittger S, Petrides PE: Akute myeloische Leukämie (AML) beim Erwachsenen; in: MANUAL: Leukämien, myelodysplastische und myeloproliferative Syndrome; hrsg. von W. Hiddemann,T. Haferlach; W. Zuckschwerdt Verlag München 2003, 17-48

Khanna KK, Jackson SP (2001): DNA double-strand breaks: signaling, repair and the cancer connection. Nat Genet 27, 247-254

Kim PM, Allen C, Wagener BM, Shen Z, Nickoloff JA (2001): Overexpression of human RAD51 and RAD52 reduces double-strand break-induced homologous recombination in mammalian cells. Nucleic Acids Res $\underline{29}$, 4352-4360

Kinzler KW, Vogelstein B (1997): Cancer-susceptibility genes. Gatekeepers and caretakers. Nature $\underline{386}, 761,763$

Lengauer C, Kinzler KW, Vogelstein B (1998): Genetic instabilities in human cancers. Nature $\underline{396}, 643-649$

Li HR, Shagisultanova El, Yamashita K, Piao Z, Perucho M, Malkhosyan SR (2004): Hypersensitivity of tumor cell lines with microsatellite instability to DNA double strand break producing chemotherapeutic agent bleomycin. Cancer Res $\underline{64}$, 4760-4767

Libura J, Slater DJ, Felix CA, Richardson C (2005): Therapy-related acute myeloid leukemia-like MLL rearrangements are induced by etoposide in primary human CD34+ cells and remain stable after clonal expansion. Blood $\underline{105}$, 2124-2131

Lieber MR (2008): The mechanism of human nonhomologous DNA end joining. J Biol Chem 283, 1-5

Lodish H, Berk A, Zipursky SL, Baltimore D, Darnell J: Molekulare Zellbiologie; 4. Auflage; Spektrum, Akademischer Verlag Heidelberg 2001

Löwenberg B, Downing JR, Burnett A (1999): Acute myeloid leukemia. N Engl J Med 341, 1051-1062

Lüllmann H, Mohr K, Wehling M: Pharmakologie und Toxikologie; 16. Auflage; Georg Thieme Verlag, Stuttgart 2006

Mandel M, Higa A (1970): Calcium-dependent bacteriophage DNA infection. J Mol Biol $\underline{53}, 159-162$

Maser RS, Monsen KJ, Nelms BE, Petrini JH (1997): hMre11 and hRad50 nuclear foci are induced during the normal cellular response to DNA double-strand breaks. Mol Cell Biol 17, 6087-6096

McKinnon PJ, Caldecott KW (2007): DNA strand break repair and human genetic disease. Annu Rev Genomics Hum Genet $\underline{8}$, 37-55 
Melo JV, Kumberova A, van Dijk AG, Goldman JM, Yuille MR (2001): Investigation on the role of the ATM gene in chronic myeloid leukaemia. Leukemia $\underline{15}$, $1448-1450$

Nowicki MO, Falinski R, Koptyra M, Slupianek A, Stoklosa T, Gloc E, NieborowskaSkorska M, Blasiak J, Skorski T (2004): BCR/ABL oncogenic kinase promotes unfaithful repair of the reactive oxygen species-dependent DNA double-strand breaks. Blood 104, 3746-3753

Nussenzweig A, Nussenzweig MC (2007): A backup DNA repair pathway moves to the forefront. Cell $\underline{131}, 223-225$

O'Driscoll M, Jeggo PA (2006): The role of double-strand break repair - insights from human genetics. Nat Rev Genet $\underline{7}, 45-54$

Pedersen-Bjergaard J, Christiansen DH, Andersen MK, Skovby F (2002): Causality of myelodysplasia and acute myeloid leukemia and their genetic abnormalities. Leukemia $\underline{16}, 2177-2184$

Penserga ET, Skorski T (2007): Fusion tyrosine kinases: a result and cause of genomic instability. Oncogene $\underline{26}, 11-20$

Pfeiffer P, Goedecke W, Kuhfittig-Kulle S, Obe G (2004): Pathways of DNA doublestrand break repair and their impact on the prevention and formation of chromosomal aberrations. Cytogenet Genome Res 104, 7-13

Phillips JW, Morgan WF (1994): Illegitimate recombination induced by DNA doublestrand breaks in a mammalian chromosome. Mol Cell Biol 14, 5794-5803

Pierce AJ, Jasin M (2001): NHEJ deficiency and disease. Mol Cell $\underline{8}, 1160-1161$

Pierce DA, Shimizu Y, Preston DL, Vaeth M, Mabuchi K (1996): Studies of the mortality of atomic bomb survivors. Report 12, Part I. Cancer: 1950-1990. Radiat Res $\underline{146}, 1-27$

Preston DL, Kusumi S, Tomonaga M, Izumi S, Ron E, Kuramoto A, Kamada N, Dohy $\mathrm{H}$, Matsuo T, Matsui T (1994): Cancer incidence in atomic bomb survivors. Part III. Leukemia, lymphoma and multiple myeloma, 1950-1987. Radiat Res $\underline{137}$, S68-97

Promega: Life Science Catalog; Mannheim 2006

Qiao Y, Spitz MR, Guo Z, Hadeyati M, Grossman L, Kraemer KH, Wei Q (2002a): Rapid assessment of repair of ultraviolet DNA damage with a modified hostcell reactivation assay using a luciferase reporter gene and correlation with polymorphisms of DNA repair genes in normal human lymphocytes. Mutat Res $\underline{509}, 165-174$

Qiao Y, Spitz MR, Shen H, Guo Z, Shete S, Hedayati M, Grossman L, Mohrenweiser $\mathrm{H}$, Wei Q (2002b): Modulation of repair of ultraviolet damage in the host-cell 
reactivation assay by polymorphic XPC and XPD/ERCC2 genotypes. Carcinogenesis $\underline{23}, 295-299$

Ramos JM, Ruiz A, Colen R, Lopez ID, Grossman L, Matta JL (2004): DNA repair and breast carcinoma susceptibility in women. Cancer $\underline{100}, 1352-1357$

Rassool FV (2003): DNA double strand breaks (DSB) and non-homologous end joining (NHEJ) pathways in human leukemia. Cancer Lett 193, 1-9

Riballo E, Doherty AJ, Dai Y, Stiff T, Oettinger MA, Jeggo PA, Kysela B (2001): Cellular and biochemical impact of a mutation in DNA ligase IV conferring clinical radiosensitivity. J Biol Chem 276, 31124-31132

Richardson C, Jasin M (2000): Frequent chromosomal translocations induced by DNA double-strand breaks. Nature $\underline{405}, 697-700$

Roddam PL, Rollinson S, O'Driscoll M, Jeggo PA, Jack A, Morgan GJ (2002): Genetic variants of NHEJ DNA ligase IV can affect the risk of developing multiple myeloma, a tumour characterised by aberrant class switch recombination. J Med Genet $\underline{39}$, 900-905

Rollinson S, Smith AG, Allan JM, Adamson PJ, Scott K, Skibola CF, Smith MT, Morgan GJ (2007): RAD51 homologous recombination repair gene haplotypes and risk of acute myeloid leukaemia. Leuk Res $\underline{31}, 169-174$

Rosenberg PS, Alter BP, Ebell W (2008): Cancer risks in Fanconi anemia: findings from the German Fanconi Anemia Registry. Haematologica $\underline{93}, 511-517$

Rothkamm K, Kuhne M, Jeggo PA, Lobrich M (2001): Radiation-induced genomic rearrangements formed by nonhomologous end-joining of DNA double-strand breaks. Cancer Res $\underline{61}$, 3886-3893

Sallmyr A, Tomkinson AE, Rassool FV (2008): Up-regulation of WRN and DNA ligase Illalpha in chronic myeloid leukemia: consequences for the repair of DNA double-strand breaks. Blood 112, 1413-1423

Sambrook J, Russell DW: Molecular Cloning: A Laboratory Manual; 3. Auflage; Cold Spring Harbor Laboratory Press, Cold Spring Harbour 2001

Sattler M, Verma S, Shrikhande G, Byrne CH, Pride YB, Winkler T, Greenfield EA, Salgia R, Griffin JD (2000): The BCR/ABL tyrosine kinase induces production of reactive oxygen species in hematopoietic cells. J Biol Chem $\underline{275}$, 2427324278

Seedhouse C, Russell N (2007): Advances in the understanding of susceptibility to treatment-related acute myeloid leukaemia. Br J Haematol 137, 513-529

Seedhouse C, Faulkner R, Ashraf N, Das-Gupta E, Russell N (2004): Polymorphisms in genes involved in homologous recombination repair interact to increase the risk of developing acute myeloid leukemia. Clin Cancer Res $\underline{10}, 2675-2680$ 
Shet AS, Jahagirdar BN, Verfaillie CM (2002): Chronic myelogenous leukemia: mechanisms underlying disease progression. Leukemia $\underline{16}, 1402-1411$

Shin A, Lee KM, Ahn B, Park CG, Noh SK, Park DY, Ahn SH, Yoo KY, Kang D (2008): Genotype-phenotype relationship between DNA repair gene genetic polymorphisms and DNA repair capacity. Asian Pac J Cancer Prev $\underline{9}$, 501-505

Slebos RJ, Taylor JA (2001): A novel host cell reactivation assay to assess homologous recombination capacity in human cancer cell lines. Biochem Biophys Res Commun 281, 212-219

Slupianek A, Nowicki MO, Koptyra M, Skorski T (2006): BCR/ABL modifies the kinetics and fidelity of DNA double-strand breaks repair in hematopoietic cells. DNA Repair (Amst) $\underline{5}$, 243-250

Smith GC, Jackson SP (1999): The DNA-dependent protein kinase. Genes Dev $\underline{13}$, 916-934

Smith J, Riballo E, Kysela B, Baldeyron C, Manolis K, Masson C, Lieber MR, Papadopoulo D, Jeggo P (2003): Impact of DNA ligase IV on the fidelity of end joining in human cells. Nucleic Acids Res $\underline{31}, 2157-2167$

Spencer A, Granter N (1999): Leukemia patient-derived lymphoblastoid cell lines exhibit increased induction of leukemia-associated transcripts following highdose irradiation. Exp Hematol 27, 1397-1401

Takatsuki K (2005): Discovery of adult T-cell leukemia. Retrovirology 2, 16

Thacker J (1994): The study of responses to 'model' DNA breaks induced by restriction endonucleases in cells and cell-free systems: achievements and difficulties. Int J Radiat Biol $\underline{66}, 591-596$

Thompson LH, Schild D (2002): Recombinational DNA repair and human disease. Mutat Res $\underline{509}$, 49-78

Thoms KM, Baesecke J, Emmert B, Hermann J, Roedling T, Laspe P, Leibeling D, Truemper L, Emmert S (2007): Functional DNA repair system analysis in haematopoietic progenitor cells using host cell reactivation. Scand J Clin Lab Invest $\underline{67}, 580-588$

Tischkowitz M, Dokal I (2004): Fanconi anaemia and leukaemia - clinical and molecular aspects. Br J Haematol 126, 176-191

Tsuzuki T, Fujii Y, Sakumi K, Tominaga Y, Nakao K, Sekiguchi M, Matsushiro A, Yoshimura Y, MoritaT (1996): Targeted disruption of the Rad51 gene leads to lethality in embryonic mice. Proc Natl Acad Sci U S A 933, 6236-6240

van Heemst D, Brugmans L, Verkaik NS, van Gent DC (2004): End-joining of blunt DNA double-strand breaks in mammalian fibroblasts is precise and requires DNA-PK and XRCC4. DNA Repair (Amst) $\underline{3}, 43-50$ 
Varga T, Aplan PD (2005): Chromosomal aberrations induced by double strand DNA breaks. DNA Repair (Amst) 4, 1038-1046

Virchow R (1845): Weisses Blut. Frorieps Notizen 36, 151-156

Walker JR, Corpina RA, Goldberg J (2001): Structure of the Ku heterodimer bound to DNA and its implications for double-strand break repair. Nature $\underline{412}, 607-614$

Wang H, Zeng ZC, Perrault AR, Cheng X, Qin W, Iliakis G (2001): Genetic evidence for the involvement of DNA ligase IV in the DNA-PK-dependent pathway of non-homologous end joining in mammalian cells. Nucleic Acids Res $\underline{29}$, 16531660

Wang H, Perrault AR, Takeda Y, Qin W, Wang H, lliakis G (2003): Biochemical evidence for Ku-independent backup pathways of NHEJ. Nucleic Acids Res 31, 5377-5388

Wang HC, Chou WC, Shieh SY, Shen CY (2006): Ataxia telangiectasia mutated and checkpoint kinase 2 regulate BRCA1 to promote the fidelity of DNA endjoining. Cancer Res $\underline{66}, 1391-1400$

Wang L, Wei Q, Shi Q, Guo Z, Qiao Y, Spitz MR (2007): A modified host-cell reactivation assay to measure repair of alkylating DNA damage for assessing risk of lung adenocarcinoma. Carcinogenesis $\underline{28}$, 1430-1436

Wei Q, Matanoski GM, Farmer ER, Hedayati MA, Grossman L (1993): DNA repair and aging in basal cell carcinoma: a molecular epidemiology study. Proc Natl Acad Sci U S A $\underline{90}, 1614-1618$

Wei YF, Robins P, Carter K, Caldecott K, Pappin DJ, Yu GL, Wang RP, Shell BK, Nash RA, Schar P (1995): Molecular cloning and expression of human cDNAs encoding a novel DNA ligase IV and DNA ligase III, an enzyme active in DNA repair and recombination. Mol Cell Biol 15, 3206-3216

Wu PY, Frit P, Malivert L, Revy P, Biard D, Salles B, Calsou P (2007): Interplay between Cernunnos-XLF and nonhomologous end-joining proteins at DNA ends in the cell. J Biol Chem 282, 31937-31943

Yoshida H, Naoe T, Fukutani H, Kiyoi H, Kubo K, Ohno R (1995): Analysis of the joining sequences of the $t(15 ; 17)$ translocation in human acute promyelocytic leukemia: sequence non-specific recombination between the PML and RARA genes within identical short stretches. Genes Chromosomes Cancer 12, 37-44 


\section{Danksagung}

Herrn Prof. Dr. Steffen Emmert danke ich für die Vergabe des interessanten Promotionsthemas sowie die geduldige und gute Betreuung.

Daneben gilt mein besonderer Dank Herrn PD Dr. Jörg Bäsecke für die konstruktiven Anregungen und Verbesserungsvorschläge bezüglich der onkologischen Thematik des Kooperationsprojektes.

Der Abteilung für Molekulare Pharmakologie unter der Leitung von Herrn Prof. Dr. W. Zimmermann danke ich für die Nutzung des Luminometers sowie des Transilluminators von $366 \mathrm{~nm}$.

Dank gilt auch den aktuellen und ehemaligen Mitarbeitern des Labors Petra Laspe, Karolin Zachmann, Antje Apel, Dr. Kai Thoms, Tina Rödling und Diana Leibeling für die Einführung in methodische Arbeiten sowie die Unterstützung bei kleinen und größeren Fragen des Laboralltages. 


\section{Lebenslauf}

Am 25.12.1981 wurde ich als erstes Kind von Herrn Karl Günther Hermann und Sabine Hermann, geb. Doht, in Bremen geboren. Nach dem Besuch der Grundschule Nord in Halstenbek von 1988 bis 1992 erfolgte der Wechsel auf das Wolfgang-Borchert-Gymnasium in Halstenbek. Nach einem Auslandsschuljahr 1998/1999 an der South Ripley Highschool in Versailles, Indiana, USA, legte ich 2001 mein Abitur ab.

Seit dem Wintersemester 2001/2002 studierte ich an der Georg-August-Universität in Göttingen Medizin. Im Rahmen meines Praktischen Jahres absolvierte ich zwei Tertiale am Klinikum Oldenburg (Pädiatrie und Innere Medizin) sowie ein Tertial am St. Bernward Krankenhaus in Hildesheim. Im Mai 2008 beendete ich mein Studium mit dem zweiten Abschnitt der Ärztlichen Prüfung.

Seit dem 1.12.2008 arbeite ich als Assistenzärztin in der Abteilung Innere Medizin am DIAKO Ev. Diakonie-Krankenhaus in Bremen. 